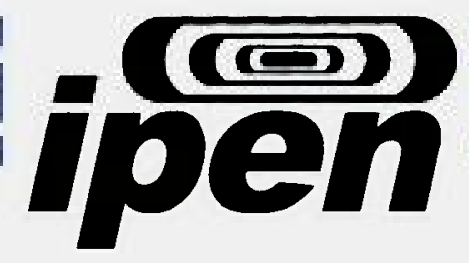

AUTARQUIA ASSOCIADA À UNIVERSIDADE DE SÃO PAULO

ESTUDO DA MICROCIRCULAÇÃO NA POLPA DENTÁRIA DURANTE A MOVIMENTAÇÃO ORTODÔNTICA VIA TÉCNICA LASER DOPPLER

ALVARO WAGNER RODRIGUES SALLES

Tese apresentada como parte dos requisitos para obtenção do Grau de Doutor em Ciências na Área de Tecnologia Nuclear - Materiais.

Orientador:

Dr. Gessé Eduardo Calvo Nogueira 
INSTITUTO DE PESQUISAS ENERGÉTICAS E NUCLEARES

Autarquia associada à Universidade de São Paulo

ESTUDO DA MICROCIRCULAÇÃO NA POLPA DENTÁRIA DURANTE A MOVIMENTAÇÃO ORTODÔNTICA VIA TÉCNICA LASER DOPPLER

ALVARO WAGNER RODRIGUES SALLES

Tese apresentada como parte dos requisitos para obtenção do Grau de Doutor em Ciências na Área de Tecnologia Nuclear - Materiais

Orientador:

Prof. Dr. Gessé Eduardo Calvo Nogueira 
INSTITUTO DE PESQUISAS ENERGÉTICAS E NUCLEARES

Autarquia associada à Universidade de São Paulo

ESTUDO DA MICROCIRCULAÇÃO NA POLPA DENTÁRIA DURANTE A MOVIMENTAÇÃO ORTODÔNTICA VIA TÉCNICA LASER DOPPLER

ALVARO WAGNER RODRIGUES SALLES

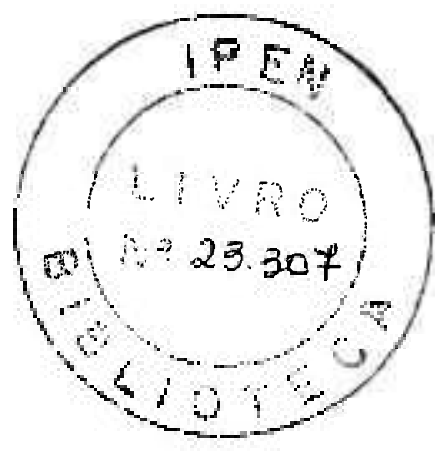

Tese apresentada como parte dos requisitos para obtenção do Grau de Doutor em Ciências na Área de Tecnologia Nuclear - Materiais

Orientador:

Prof. Dr. Gessé Eduardo Calvo Nogueira

SÃo PAULO 
Adriana. minha esposa e amor da minha vida.

Obrigado por estes momentos maravilhosos que compartilhamos, Pela sua total dedicação como esposa e mãe, Eu te amo. 
Aos meus pais, obrigado pela base sólida na formação do meu caráter.

Minha mamãezinha querida, Clélia, obrigado por todo amor e desprendimento de uma vida.

Ao meu amado pai Georgino, pela força de caráter e exemplo de firmeza nas atitudes.

Obrigado por me amarem tanto. 
Ao meu filho, Álvaro, a quem eu amo tanto e ainda não nasceu.

Que Deus me dê saberia para educa-lo.

Que eu possa ser o exemplo de pai como o meu foi para mim.

Que eu possa ama-lo como fui amado por minha mãe.

Você é a presença viva do amor entre sua mãe e eu. 
Ao meu irmão Alexandre, obrigado pelos momentos de nossa vida.

Querida Andréa, obrigado por fazer parte de nossa vida e ser mãe de duas maravilhosas meninas.

As minhas queridas sobrinhas, Geórgia e Alessandra, obrigado pelo amor. 
Marilena e Leonardo, obrigado pelo amor de toda uma vida. Eu os amo. 


\section{Agradecimento especial}

Ao Prof. Dr. Gessé Eduardo Calvo Nogueira, meu agradecimento sincero, pelo seu saber e orientação do trabalho. Obrigado por me fazer ser um melhor profissional e ser um excelente professor. Minha sincera admiração. 


\section{AGRADECIMENTOS}

À Sociedade Paulista de Ortodontia na figura do Prof. Dr. Jairo Corrêa, pela porta sempre aberta desta maravilhosa casa.

Ao Prof. Dr. Rubens Simões de Lima, coordenador do curso de ortodontia da SPO e seus assistentes, Castelo, Eduardo, Suzuki e Laura, por me acolherem de braços abertos.

Aos alunos do curso de especialização em ortodontia da SPO, pela paciência e agradável convívio.

À Ana Paula Furkim, grande amiga há 20 anos, obrigado por todos os momentos que passamos juntos na elaboração deste trabalho na SPO.

Ao Prof. Dr. José Luiz Lage-Marques, à Profa. Dra. Célia Regina Martins Delgado Rodrigues, à Profa. Dra. Denise Maria Zezell, à M. Sc. Ana Lúcia Farnezi Nogueira, à Profa. M. Sc. Flávia Tavarez de Oliveira de Paula Eduardo, à Profa. Dra. Márcia Turolla Wanderley e ao José Tort Vidal meus agradecimentos pelas colaborações diretas ou indiretas durante a realização deste trabalho.

Ao Prof. Dr. João Batista de Paiva, meu agradecimento pelas sugestões durante a realização deste trabalho. 
Aos meus queridos amigos Sérgio Nakazone Jr., Sérgio Terçarolli, Murilo Corsi, Paulo Saram e Fábio Strutzel obrigado pela contribuição direta e indireta nesta obra.

Minha querida Mirian Cotrim agradeço pelo apoio e dedicação.

Ao IPEN pela oportunidade e suporte técnico.

Ao CNPq e à FAPESP pelo suporte financeiro. 


\title{
ESTUDO DA MICROCIRCULAÇÃO NA POLPA DENTÁRIA DURANTE A MOVIMENTAÇÃO ORTODÔNTICA VIA TÉCNICA LASER DOPPLER
}

\author{
Alvaro Wagner Rodrigues Salles
}

\section{Resumo}

Alterações celulares e neurovasculares na polpa têm sido relacionadas a forças ortodônticas, usadas na movimentação dentária. As alterações observadas são geralmente relacionadas a alterações vasculares na polpa. Os primeiros estudos sobre alterações do fluxo sangüineo pulpar (FSP) durante a movimentação dentária foram realizados usando técnicas qualitativas (e. g., cortes histológicos), e quantitativas (e. g., micro-esferas radioativas ou fluorescentes, radioespirometria). Tais técnicas são invasivas, destrutivas e não permitem o estudo de alteraçōes dinâmicas do fluxo. Recentemente a fluxometria laser Doppler (FLD), uma técnica não invasiva, tem sido usada no estudo de alterações dinâmicas do FSP em humanos em condições próximas às reais. Mas os estudos disponiveis na literatura, usando a FLD, ainda são limitados a movimentos experimentais, pois ainda existem limitações práticas na FLD.

O objetivo desta pesquisa foi, usando a FLD, estudar alteraçōes do FSP de voluntários submetidos a duas fases de um tratamento ortodôntico corrente (nivelamento e retração), dentro de condições clinicas reais.

Doze voluntários foram monitorados durante a fase de nivelamento $e$ treze voluntários foram monitorados durante a fase de retração. antes da aplicação de forças, 20 minutos, 48h, 72h e 1 mês depois de aplicadas as forças.

Analisando os resultados obtidos, durante as duas fases estudas foram encontradas evidências estatísticas suficientes para inferir que ocorrem alterações significativas no FSP, quando medidas via FLD, durante os movimentos e forças estudadas, nos seguintes momentos investigados: diminuição do FSP nos momentos 20 minutos, 48h e 72h. Durante o nivelamento, no dia 30 o FSP é próximo ou igual ao basal. Durante a retração, no dia 30 o fluxo ainda permanece diminuído. 


\title{
A DENTAL PULP MICROCIRCULATION STUDY DURING ORTHODONTIC MOVEMENT VIA LASER DOPPLER TECHNIQUE
}

\author{
Alvaro Wagner Rodrigues Salles
}

\begin{abstract}
Cellular and neurovascular changes in the pulp have been related to orthodontic forces, used to produce a dental movement. The observed alterations are generally related to pulpal vascular changes. Earlier studies on pulpal blood flow (PBF) changes during the dental movement were carried out by using qualitative techniques (e. g., histological slices), and quantitative (e. g., radioactive or fluorescent microspheres, radiospirometry). Such techniques are invasive, destructive, and do not allow dynamic flow changes to be studied. Recently the laser Doppler flowmetry (LDF), a non-invasive technique, has been used to study dynamic PBF alterations in humans into nearly real conditions. The available studies in the literature, by using the LDF, are limited to experimental studies, probably due to the LDF practical limitations.

The aim of this work was, by using the FDF, to study PBF alterations from volunteers subjected to two phases of a current orthodontic treatment (leveling and retraction), into real clinical conditions.

Twelve volunteers were monitored during the leveling phase and thirteen volunteers were monitored during the retraction phase, before the force to be applied, and 20 minutes, $48 \mathrm{hr}, 72 \mathrm{hr}$ and 1 month later.

Analyzing the obtained results, during the two studied phases, it were found suffice statistical evidences to infer that significant PBF decrease occurs on the investigates moments: 20 minutes, $48 \mathrm{hr}$ and $72 \mathrm{hr}$. During the leveling phase, on day 30 , the PBF is near or equal to the basal level. During the retraction, on day 30 , the flow is still decreased.
\end{abstract}




\section{SUMÁRIO}

1. Introdução

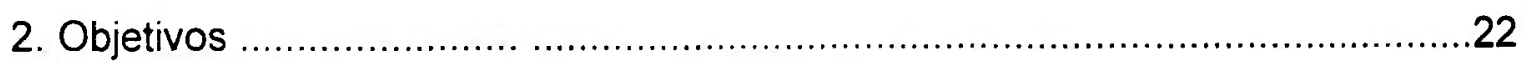

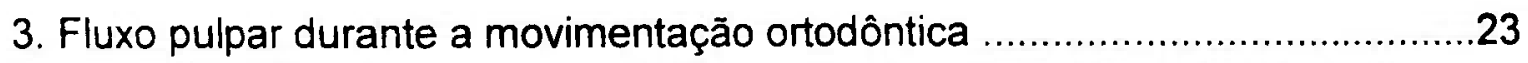

3.1. Microcirculação pulpar e a inflamação neurogênica ..........................24

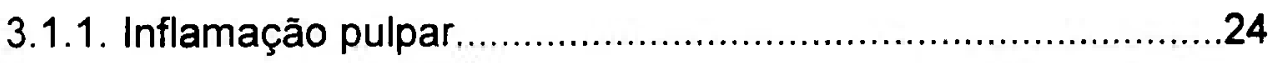

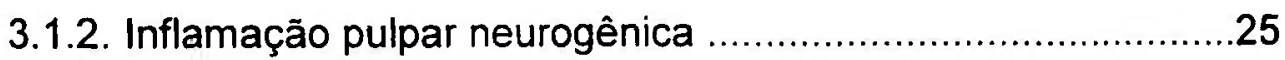

3.2. Alterações do fluxo pulpar e peridental na movimentação

ortodôntica.

3.3. Principios de funcionamento, características e limitaçōes

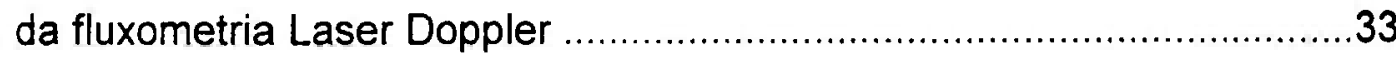

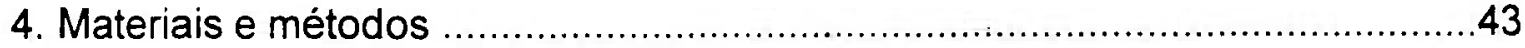

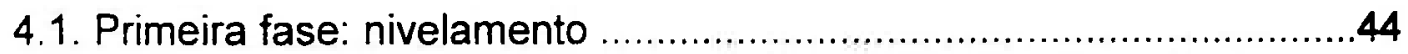

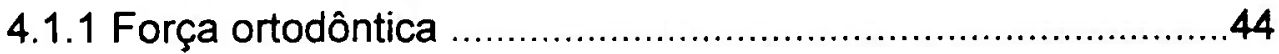

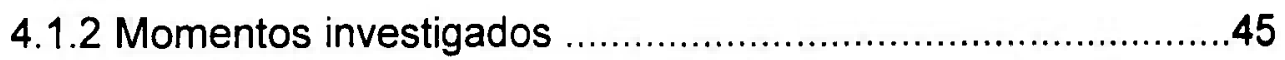

4.1.3 Suporte de fixação da sonda ..............................................45

4.1.4 Fluxômetro Laser Doppler .....................................................46

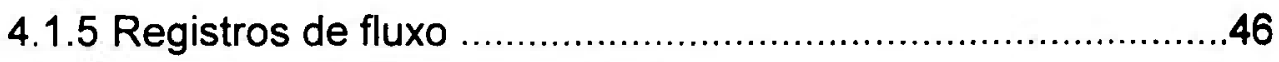

4.1.6 Indicadores de variaçōes de fluxo ........................................49

4.1.7 Controle e estabilidade dos registros …….............................49

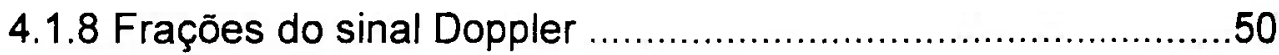

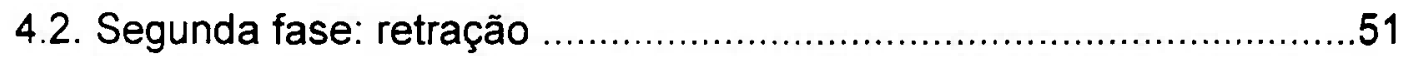

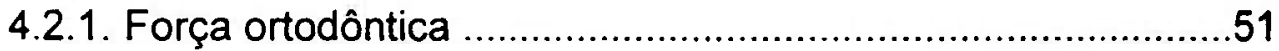


5.1. Controle e estabilidade dos registros 53

5.2. Frações do sinal Doppler ....................................................55

5.3. Alterações de fluxo durante o nivelamento ................................58

5.4. Alterações de fluxo durante a retração .....................................65

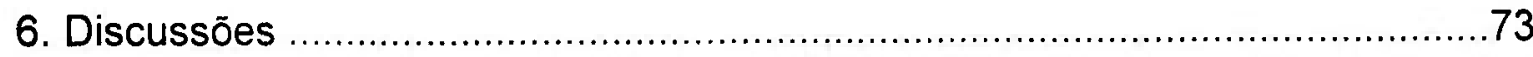

6.1 Significado dos indicadores de alterações de fluxo ........................74

6.1.1. Frações de fluxo pulpar, gengival e periodontal .................74

6.1.2. Indicadores de alterações de fluxo ................................81

6.1.3. Controle e estabilidade dos registros ........................... 83

6.2. Alterações de fluxo periodontal durante a movimentação ortodôntica .83

6.3. Alterações de fluxo gengival durante a movimentação ortodôntica .85

6.3.1. Inflamação .85

6.3.2. Influência de cargas mecânicas no fluxo gengival .87

6.4. Alterações do fluxo pulpar durante a movimentação ortodôntica .89

6.4.1. Inflamação neurogênica da polpa seguida por elevação

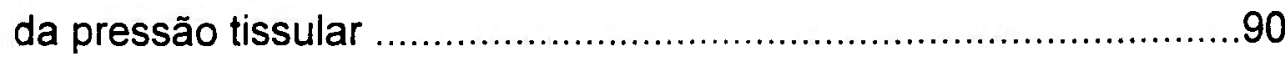

6.4.2. Compressão vascular na raiz dental ..............................94

6.5. Considerações sobre os movimentos e sessões investigadas ..........95

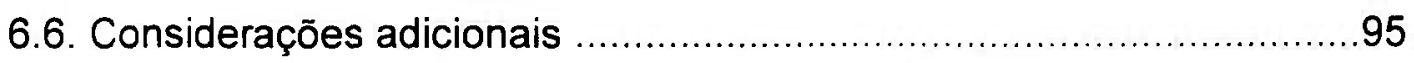

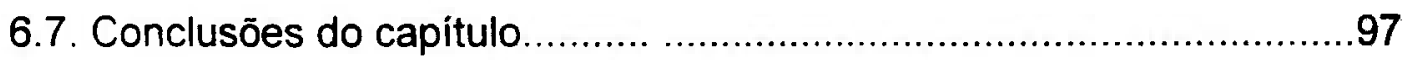

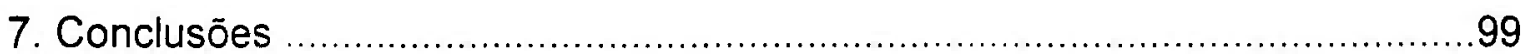

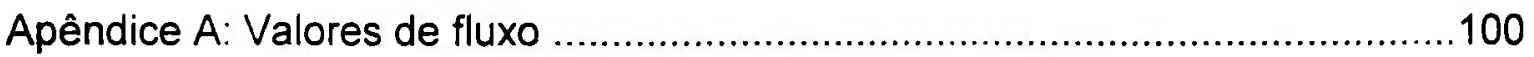

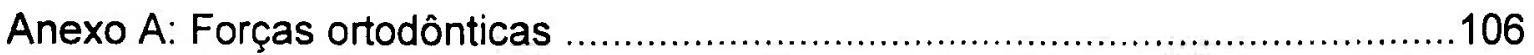

Anexo B: Movimentação ortodôntica........................................................111 
Anexo C: Anatomia e fisiologia da microcirculação pulpar 


\section{LISTA DE ABREVIATURAS E SIGLAS}

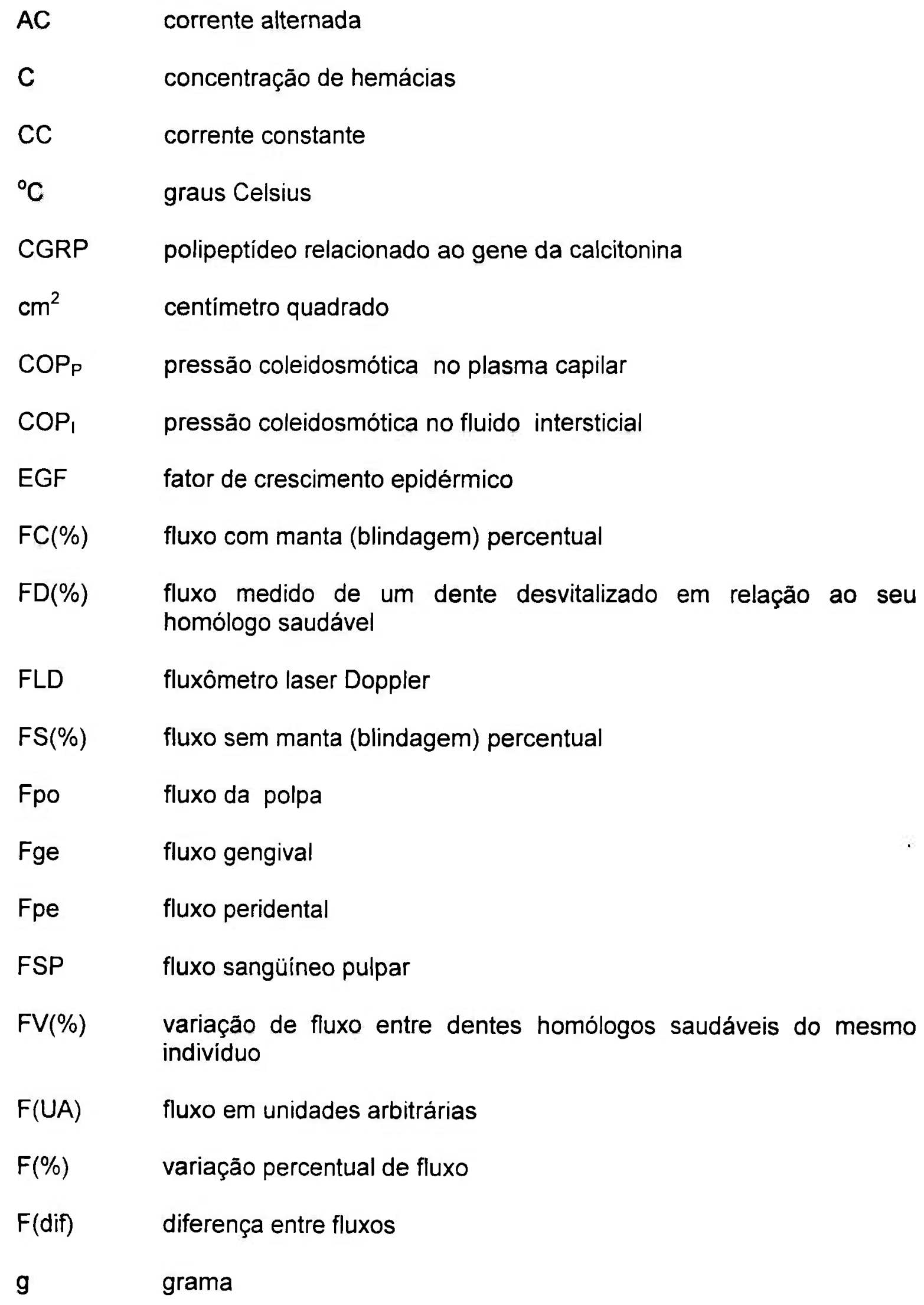




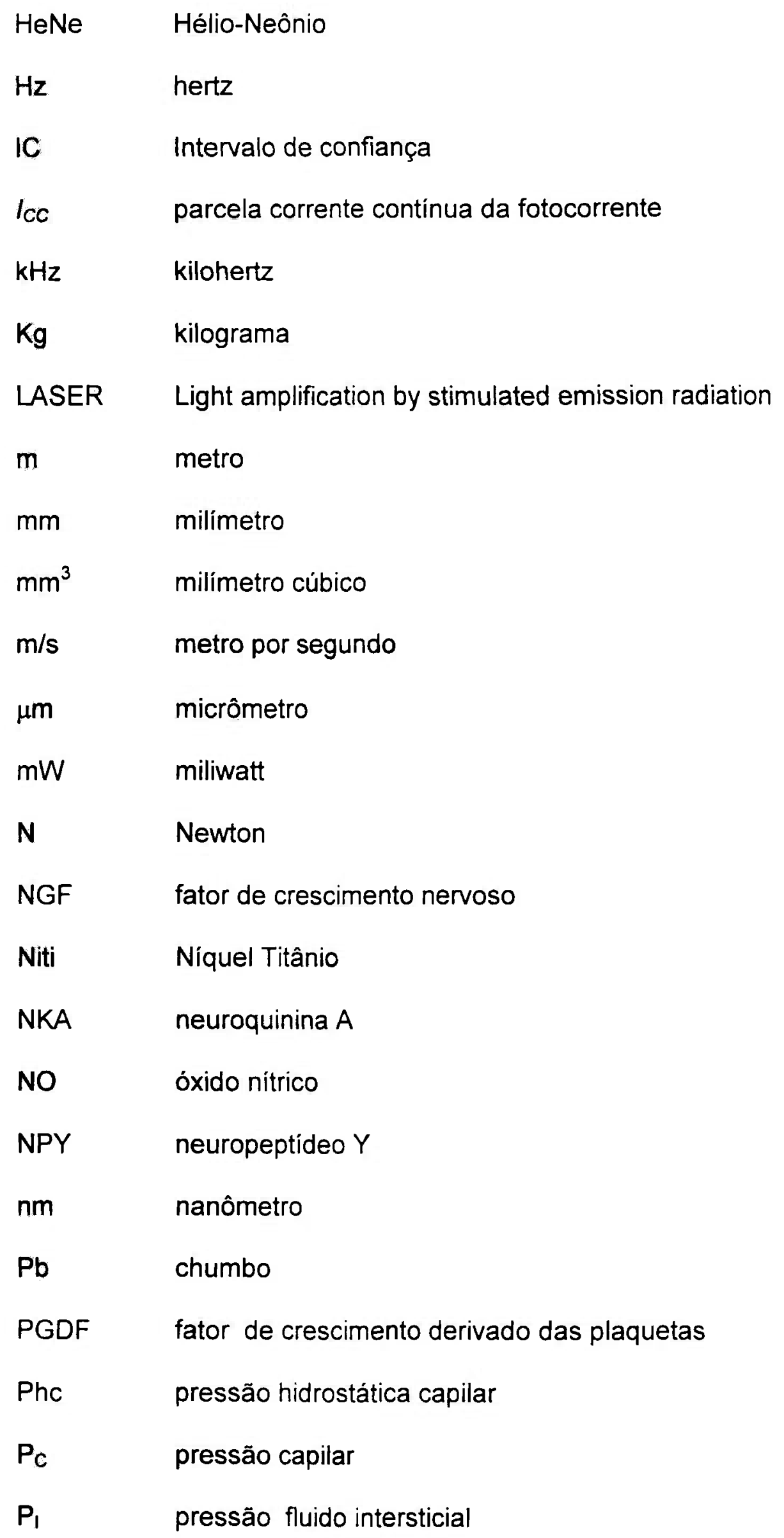




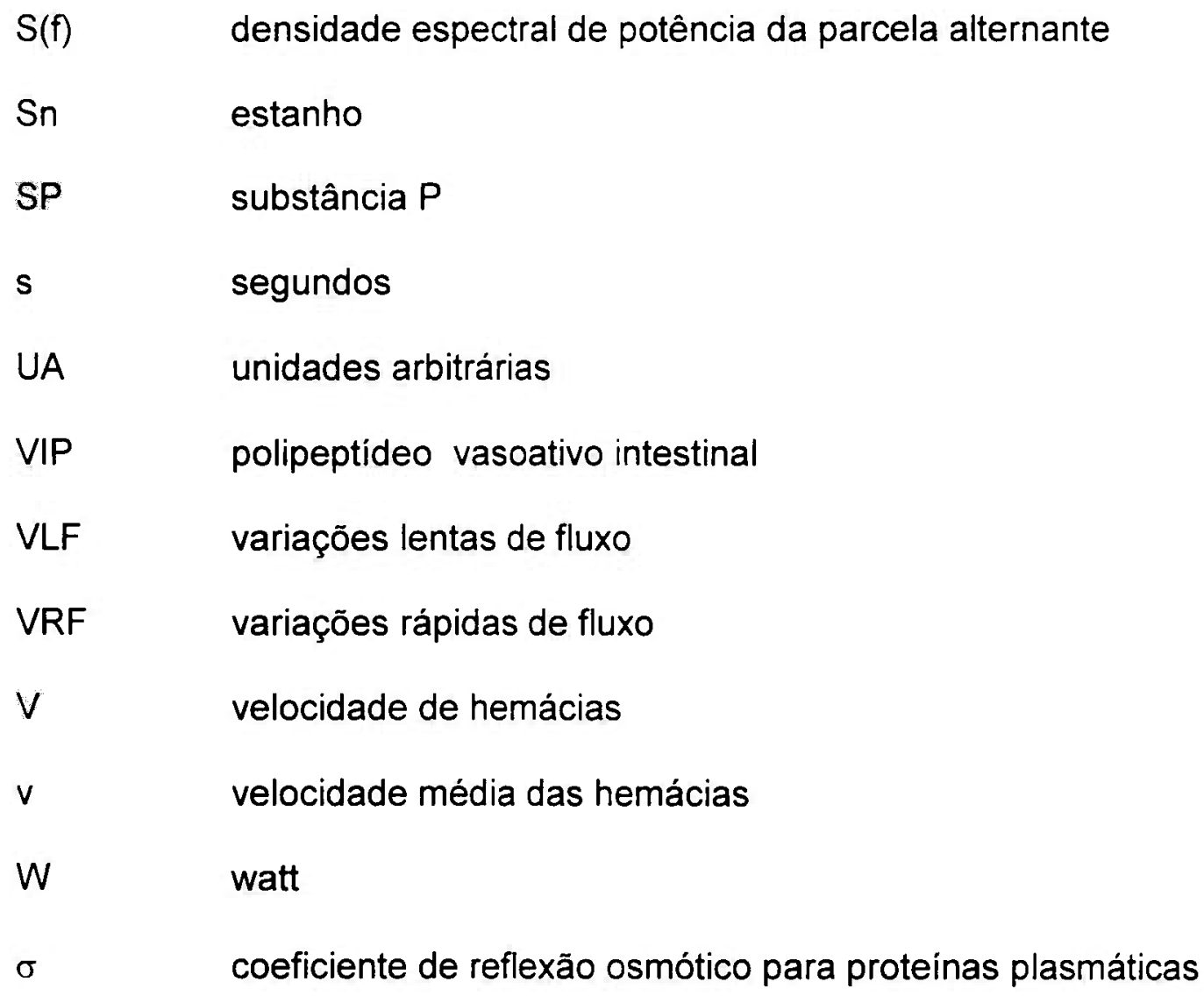




\section{INTRODUÇÃO}

Ortodontia é um ramo da odontologia relacionado principalmente com o estudo do crescimento do complexo crâniofacial, com o desenvolvimento da oclusão dental, com a prevenção e o tratamento das anomalias oclusivas dentárias.

A movimentação dentária, promovida pela aplicação de forças mecânicas, é um procedimento ortodôntico usado na prevenção e no tratamento do desequilibrio oclusal.

Atualmente há consenso que um tratamento ortodôntico quando indicado deve ser instituído, observando o compromisso entre os benefícios e os efeitos adversos do tratamento.

Paralelamente ao desenvolvimento de novas técnicas e novos materiais na área da ortodontia, aprimorando os resultados, têm sido relatados efeitos adversos supostamente decorrentes da movimentação dentária. Dentre os efeitos adversos relatados, a reabsorção radicular (Hamiltom e Guttman, 1999; Villa et al., 2004), a deposição de dentina secundária (Villa et al., 2004), alterações celulares, vasculares e neurais (Vandevska-Radunovic, 1999) têm sido alvos de muitas investigações.

Há evidências sugerindo que durante o esforço mecânico pode ocorrer, inicialmente, a diminuição do fluxo pulpar, decorrente do estrangulamento dos vasos sangüineos que irrigam a cavidade pulpar (McDonald e Pitt Ford, 1994). Também foi sugerido que a movimentação dentária pode induzir um processo inflamatório neurogênico na polpa, Hamiltom e Guttman (1999).

Embora o processo de reabsorção radicular ainda não seja totalmente conhecido, Hamiltom e Guttman (1999) sugerem que alterações no sistema neurovascular pulpar decorrentes de movimentos ortodônticos podem iniciar o processo de reabsorção. Historicamente outras complicações iatrogênicas da polpa e da raiz dental decorrentes da movimentação têm sido relacionadas a alteraçōes vasculares na polpa (e. g., Oppenheim, 1942; Reitan, 1951). Assim o estado de suprimento sangüineo pulpar durante procedimentos ortodônticos tem 
sido alvo de investigações há mais de sessenta anos. Neste sentido, muitos estudos têm sido realizados procurando correlacionar esforços mecânicos com o fluxo vascular no dente e em seus tecidos de suporte.

Nos estudos iniciais, a avaliação do fluxo pulpar foi efetuada indiretamente, observando os tecidos alterados, i. e., estudos observando cortes histológicos (e. g., Anstendig e Kronman, 1972). Mais recentemente, outras técnicas foram usadas: a observação direta por microscópio (Guevara e McClugage, 1980), a taxa de respiração tecidual (Unsterseher et al., 1987) e a injeção de microesferas fluorescentes (Vandevska-Radunovic et al., 1994). Estas técnicas são, no entanto, limitadas pois permitem uma única observação de cada dente examinado, num único instante do tempo, não permitindo um acompanhamento de um mesmo individuo ao logo do tempo. Ainda, por serem técnicas ou invasivas ou destrutivas, são normalmente usadas em modelos (animais), durante movimentos experimentais. Como conseqüência, o conhecimento atual sobre a hemodinâmica pulpar ainda é limitado.

Mais recentemente a fluxometria laser Doppler, atualmente considerada a técnica mais adequada ao estudo da dinâmica do fluxo sangüíneo microvascular (Clough et al., 2002), tem sido utilizada no estudo da microcirculação de praticamente todos os órgãos do corpo humano. A técnica permite medir o fluxo na polpa humana intacta, apresentando as vantagens, em relação aos outros métodos, de não ser invasiva, de não oferecer riscos aos pacientes e principalmente por permitir o estudo em tempo real de vários parâmetros hemodinâmicos, tais como o fluxo, a velocidade e a concentração das hemácias contidas no volume ao qual o instrumento é sensível.

Na odontologia, como um exemplo, a fluxometria laser Doppler tem sido usada para verificar a vitalidade da polpa dentária (Evans et al., 1999; Roeykens et al., 1999 ).

A fluxometria laser Doppler também viabiliza o estudo das alteraçōes de fluxo pulpar durante a movimentação dentária nas condições clínicas reais, durante longos periodos, que são características dificilmente atingiveis quando outras técnicas de monitoramento do fluxo são usadas. No entanto, a informação disponivel na literatura sobre os efeitos da movimentação dentária no fluxo pulpar em humanos via fluxometria laser Doppler ainda é limitada: o efeito de forças intrusivas intermitentes foi estudado por Brodin et al. (1996), Barwick e Ramsay 
(1996) e lkawa et al. (2001), o efeito de forças intrusivas continuas foi estudado por Sano et al. (2002), o efeito de forças horizontais (movimento de corpo ou translação) por McDonald e Ford (1994). Estes estudos foram realizados em movimentos experimentais descontinuados após um periodo pequeno de observação, quando comparado ao período médio de reativação das forças ortodônticas. Não foram encontrados, na literatura relacionada, estudos realizados dentro de condições clínicas reais. Esta escassez de estudos decorre provavelmente dos seguintes principais fatores: a fluxometria laser Doppler, quando aplicada ao estudo da microvascularização pulpar, é uma técnica que está sendo desenvolvida, e ainda existem limitações práticas. Como exemplos, para minimizar as limitações, estão sendo desenvolvidos métodos de fixação da sonda, métodos de processamento do sinal Doppler, métodos de eliminação de interferências produzidas pelo fluxo gengival e métodos de interpretação dos resultados. As limitaçōes são importantes quando o periodo de estudo é longo, que é o caso do estudo da movimentação dentária durante processos ortodônticos.

A alteração do fluxo sangüíneo na polpa é um processo dinâmico, cujo acompanhamento é possibilitado com o uso da técnica laser Doppler. Como uma decorrência da escassez de trabalhos nesta área, os dados disponiveis ainda são insuficientes para correlacionar padrões de fluxo com a ocorrência dos efeitos indesejáveis decorrentes de um tratamento ortodôntico. 


\section{OBJETIVOS}

O objetivo deste trabalho foi investigar a existência de alterações no fluxo sangüíneo pulpar de incisivos centrais permanentes em humanos, usando a técnica laser Doppler, antes e durante a aplicação de forças ortodônticas que promoveram os movimentos predominantes de inclinação e translação, dentro de condições clínicas reais.

Os movimentos predominantes de inclinação e translação, correspondentes às fases de nivelamento e retração, foram estudados em pacientes com maloclusões Classe II, Subdivisão | de Angle, submetidos ao tratamento ortodôntico com aparelho fixo, usando fios superelásticos no nivelamento e arcos dupla chave de aço na fase de retração.

Durante cada fase do tratamento as forças ortodônticas foram reativadas depois de periodos de 30 dias. O estudo foi limitado aos periodos iniciais de cada fase do tratamento, ou seja, durante 30 dias depois da primeira ativação de forças em cada fase. 


\section{FLUXO PULPAR DURANTE A MOVIMENTAÇÃO ORTODÔNTICA}

Um dos resultados desejáveis das forças ortodônticas é a remodelagem óssea resultando um movimento dental planejado, acompanhada pela remodelagem do ligamento periodontal (ou eventualmente recuperação), gengiva, nervos e vasos sangüineos. No entanto ainda não estão totalmente elucidados os mecanismos que levam ao movimento dentário assim como os efeitos adversos resultantes das forças ortodônticas. Assim é atual e elevado o interesse em conhecer o movimento ortodôntico e suas conseqüências.

Dentre outros efeitos iatrogênicos, têm sido relatadas alterações na gengiva, polpa, ligamento periodontal (LPD) e osso alveolar que podem ser caracterizadas como uma resposta inflamatória inicial até reabsorções radiculares, formação de dentina secundária e necrose pulpar. Mas tais alterações estão intimamente relacionadas ou até originadas por alterações microcirculatórias. Avaliar as alterações vasculares na gengiva, polpa e ligamento periodontal torna-se então de suma importância.

A avaliação direta das alterações microcirculatórias no LPD, osso alveolar e polpa é impossivel pela sua anatomia. Assim tem sido comum a inferência de alterações microcirculatórias partindo de observações em cortes histológicos e outras técnicas invasivas citadas no Capítulo 1. Somente recentemente a fluxometria laser Doppler (FLD) permitiu o estudo de alterações microcirculatórias na polpa e gengiva em humanos, possibilitando avançar no conhecimento das alterações dinâmicas microcirculatórias.

Este capitulo apresenta uma sinopse de achados sobre alterações mórficas e ou funcionais da movimentação ortodôntica, focando as alterações dinâmicas microvasculares da polpa mais recentemente investigadas usando a fluxometria laser Doppler, por estarem diretamente relacionadas ao presente trabalho. Antes, porém, uma vez que há evidências crescentes sugerindo a possibilidade de ocorrer inflamação pulpar neurogênica na movimentação dentária ortodôntica, neste capítulo é apresentado um breve resumo do controle neurovascular pulpar focando a inflamação neurogênica. Na seqüência é apresentado um breve, mas 
abrangente e atual resumo sobre os principios de funcionamento, caracteristicas e limitações da fluxometria laser Doppler quando aplicada ao estudo do fluxo pulpar em dentes intactos, que são as bases mínimas necessárias às justificativas tanto deste trabalho quanto dos métodos usados.

Sinopses sobre os seguintes tópicos podem ser úteis: Forças Ortodônticas, apresentada no ANEXO A; Movimentação Ortodôntica, apresentada no ANEXO B; Anatomia e Fisiologia da Microcirculação pulpar, apresentadas no ANEXO C.

\subsection{Microcirculação pulpar e a inflamação neurogênica}

O estado do suprimento sangüíneo na polpa dental è de fundamental importância não somente para a nutrição, trocas gasosas, remoção de metabólitos e dejetos da polpa, como também para os mecanismos de defesa a insultos. Esta subseção apresenta um breve resumo do conhecimento atual sobre a dinâmica da circulação sangüínea pulpar quando ocorre um insulto, e na seqüência, sobre as alteraçōes neurovasculares que participam das alterações vasculares que ocorrem quando há um insulto ou estímulo.

\subsubsection{Inflamação pulpar}

Atualmente há duas hipóteses sobre os mecanismos e seqüências de eventos que ocorrem na inflamação pulpar.

Nos primeiros momentos da inflamação pulpar ocorrem a vasodilatação e o aumento da permeabilidade vascular, induzidas por estímulos ou agressões. A vasodilatação causa um aumento na filtração capilar $e$, por conseguinte, um aumento no volume do fluido intersticial. $O$ aumento da permeabilidade leva a um derrame de proteinas plasmáticas no tecido, aumentando a concentração de soluto intersticial. O aumento no volume do fluido e soluto na polpa acarreta um aumento de pressão intersticial pulpar (PIP). É conjecturado que a PIP aumentada, decorrente do processo inflamatório, pode resultar na compressão vascular, hipóxia e necrose pulpar, seguindo um curso catastrófico, similar ao de um edema em tecidos enclausurados, como é o caso do cérebro (Kim, 1990).

Outra possibilidade à hipótese precedente é que ocorra a drenagem do fluido intersticial via vasos linfáticos e capilares. Neste caso a PIP não aumentaria 
a niveis tão elevados, resultando um curso mais favorável à reparação da polpa (Heyeraas e Kvinnsland, 1992).

\subsubsection{Inflamação pulpar neurogênica}

Em resposta a estímulos, células nervosas sensoriais geram impulsos elétricos que atravessam toda a célula chegando à região dos dendritos, onde o estímulo elétrico é transformado em sinal químico. As substâncias químicas liberadas, denominadas neurotransmissores, atravessam a sinapse nervosa e ativam o próximo neurônio criando um circuito nervoso sensorial. Assim o papel de neurotransmissores no circuito nervoso sensorial é bem estabelecido. Mas em 1901 Bayliss fez as primeiras observações que a ativação do gânglio da raiz dorsal nervosa resulta em uma vasodilatação periférica (apud Lundy e Linden, 2004). Resposta semelhante foi mais tarde observada por Lewis (1927) quando estimulou a pele com um objeto aguçado e denominou este mecanismo de resposta trifásica (apud Lundy e Linden, 2004), abrangendo uma seqüência de eventos: i) vasoconstrição decorrente da reação dos capilares ao estímulo mecânico externo; ii) vasodilatação ao redor da lesão decorrente da vasodilatação vascular e; iii) edema devido ao aumento da permeabilidade capilar. Assim foi proposto que a estimulação de axônios sensoriais também podem resultar uma resposta inflamatória e este processo tem sido denominado inflamação neurogênica.

Em 1931 Von Euler e Gaddum isolaram uma sustância capaz de diminuir a pressão sangüínea, denominada Substância $P$ de powder (SP). Lembeck em 1953 postulou que a SP poderia ser um neurotrasmissor sensorial. Esta teoria foi estudada e foi demonstrado que o sistema nervoso atua sobre os aspectos vasculares da inflamação e o termo inflamação neurogênica foi utilizado para definir a contribuição do sistema nervoso sensorial na resposta inflamatória local (apud Lundy e Linden, 2004).

As substâncias que atuam na inflamação neurogênica são peptídeos neurotransmissores denominados neuropeptídeos, e são definidos como substâncias sintetizadas e liberadas por neurônios que possuem ação biológica por intermédio da via extracelular de receptores e células alvo (Lundy e Linden, 2004). 
Em 1988 Davidovitch et al. propuseram pela primeira vez que a inflamação neurogênica poderia atuar no ligamento periodontal como conseqüência de forças ortodônticas (apud Vandevska-Radunovic, 1999).

Mais recentemente foi proposto que a liberação de SP e CGRP (outro neuropeptideo) pelas fibras nervosas sensoriais no ligamento periodontal, decorrente de forças mecânicas, produz um complexo e intrínseco mecanismo com atuação direta sobre os fibroblastos (i), proliferando-os; mastócitos (ii), que liberariam histaminas, leucotrienos e prostaglandinas, agindo sobre o sistema circulatório promovendo vasodilatação; macrófagos (iii), aumentando as atividades fagocitárias, que liberariam citocinas e prostaglandinas, promovendo o aumento da atividade de osteoblastos (iv) (também promovida diretamente pela ação dos neuropeptídeos) e diminuição da atividade de osteoclastos ( $v$ ) (também diretamente promovida pela ação dos neuropeptideos), sugerindo que os mecanismos neurogênicos fazem parte e modulam o desenvolvimento da inflamação inicial, como também o processo reparatório tardio pertencente ao movimento ortodôntico dental, Vandevska-Radunovic (1999).

$\mathrm{Na}$ polpa dental, Fristad et al. (1997) sugeriram que a inflamação neurogênica seria uma associação de eventos, começando pela estimulação de uma fibra nervosa sensorial na polpa dental que liberaria SP e CGRP, promovendo a vasodilatação e incremento do fluxo sangüíneo. Estes neuropeptideos também promoveriam o aumento da permeabilidade vascular resultando um aumento da filtração vascular.

Os neuropeptídeos liberados pelos axônios sensoriais mais conhecidos são: a substância $P$ (SP), a neuroquinina $A$ (NKA), o peptideo relacionado ao gene da calcitonina (CGRP), o neuropeptideo $Y$ (Gazileus et al., 1987; Olgart, 1996; Lundy e Linden, 2004) e o polipeptídio vasoativo intestinal (VIP) (Lundy e Linden, 2004).

A substância $P$ e a neuroquinina $A$ causam vasodilatação pela ação direta na musculatura lisa da célula vascular e indiretamente por estimular a emissão de histamina pelos mastócitos (Lundy e Linden, 2004).

O peptídeo relacionado ao gene da calcitonina, CGRP, é potente vasodilatador (Lundy e Linden, 2004), atua como um guia no tráfego de células imunológicas através das paredes dos vasos sangüíneos, atuando também sobre macrófagos e leucócitos (Vandevska-Radunovic et al., 1997). 
O polipeptídeo vasoativo intestinal (VIP) apresenta capacidade imunossupressora na qual acredita-se prevenir a excessiva produção de citocinas pró-inflamatórias.

O neuropeptídeo $Y$ (NPY) é um potente vasoconstritor e amplificador dos efeitos pós-sinápticos de outros vasoconstritores, como a noradrenalina (Lundy e Linden, 2004).

Os estudos dos neuropeptideos têm sido realizados utilizando-se técnicas imunohistoquímicas em humanos (Rood e Boissonade, 2003) e em animais (Fristad et al., 1997; Yu et al., 2002; Vandevska-Radunovic et al., 1997). Em animais os estudos imunohistoquimicos podem estar associados a simpatectomia (Haug e Heyeraas, 2003; Haug et al., 2003), sendo portanto mais seletivos.

Rood e Boissonade (2003) avaliaram a relação anatômica entre os neurônios que liberam neuropeptídeos e vasos sangüineos na polpa em dentes humanos permanentes e decíduos extraídos durante anestesia geral usando a técnica imunorreativa. Os autores constataram que aproximadamente $20 \%$ das arteriolas com paredes finas observadas na região média coronal da polpa dental apresentavam inervação positiva a neuropeptídeos. Capilares, vênulas e vasos linfáticos não apresentavam inervação associada próxima. Das fibras imunorreativas encontradas, as seguintes frações foram observadas: $92 \%$ imunorreativas à CGRP, $87 \%$ à SP, $80 \%$ à NPY e $15 \%$ à VIP.

Haug et al. (2003) utilizaram a associação do movimento ortodôntico com os efeitos da simpatectomia (remoção do gânglio cervical superior) observando em ratos que no lado em que foi feita a simpatectomia houve um aumento significativo de reabsorção radicular, aumento da atividade da SP e ausência do NPY no ligamento periodontal, onde houve compressão no movimento ortodôntico quando comparado ao lado controle. Na polpa do dente movimentado houve um aumento da densidade das fibras reativas a SP, concluindo os autores que o movimento ortodôntico induz a remodelação não somente no ligamento periodontal, mas também na polpa dental.

Associando os resultados de Haug et al. (2003) e Haug e Heyeraas (2003), observa-se que a atividade do NPY está diretamente associada à atividade óssea, pois onde houve a simpatectomia ocorreu um aumento da atividade de osteoclastos e lesões periapicais. 
A inflamação neurogênica é uma resposta complexa que não está associada somente aos eventos nervosos. De fato, é conhecido que o início e manutenção da inflamação neurogênica depende de uma variedade de fatores presentes no local. Destacam-se outros moduladores além dos neuropeptídeos tais como as citocinas, o fator de crescimento nervoso (NGF), a bradicinina e o óxido nitrico (NO).

As interações entre citocinas e neuropeptídeos são bidirecionais, isto é, citocinas e outros produtos das células imunológicas podem modular a ação, diferenciação e a sobrevida das células nervosas, enquanto os neuropeptídeos liberados pelos axônios desenvolvem papel importante na influência da resposta imunológica (Lundy e Linden, 2004).

O fator de crescimento nervoso (NGF) atua no desenvolvimento e manutenção do sistema periférico simpático como nos axônios sensoriais nociceptivos. Durante processos inflamatórios prolongados é responsável pelo aumento da sintese de SP e CGRP (Lundy e Linden, 2004).

A bradicinina é uma substância pró-inflamatória, levando à vasodilatação e ao extravasamento de plasma, liberando outros mediadores como a SP e o CGRP (Lundy e Linden, 2004).

O óxido nítrico (NO) é um gás neurotransmissor que atua como vasodilatador, relaxando a musculatura lisa (Lundy e Linden, 2004).

As atuações de alguns desses mediadores na polpa dental são propostas por Olgart (1990) e por Heyeraas e Kvinnsland (1992): a ativação de axônios sensoriais como as fibras tipo $A$ e $C$ induzem a liberação de neuropeptídeos promovendo a vasodilatação. Os neuropeptídeos podem atuar em diferentes direções causando o relaxamento da musculatura lisa vascular e aumento do fluxo sangüíneo, o mecanismo de ação direta seria a atuação da CGRP e SP sobre o vaso. Indiretamente ocorreria a liberação de agentes inflamatórios como histamina, prostaglandinas e bradicinina (substâncias vasodilatadoras). Ou seja, sobre um estimulo local, supostamente duas vias nervosas atuariam. Uma ativada pelo simpático, que promoveria vasoconstrição e outra pela via sensitiva, através SP e CGRP, que promoveriam a vasodilatação. Numa ativação reflexa no sistema simpático, liberar-se-ia em um segundo momento noradrenalina (NA) que atuaria no efeito da CGRP e SP. Este mecanismo atuaria sobre condições fisiológicas, 
mas na instalação do processo inflamatório as fibras sensoriais dominariam, Olgart (1996).

\subsection{Alterações do fluxo pulpar e peridental na movimentação ortodôntica}

Oppenheim (1942) avaliou cortes histológicos em dentes humanos submetidos a um tratamento ortodôntico sob a ação de molas de aço e fios para separar os dentes por um período de 24 horas, observou capilares dilatados e diapedese de eritrócitos, sugerindo que ocorreu um aumento da pressão nos vasos sangüíneos. Também foi observado que pequenos distúrbios circulatórios nos vasos da polpa estão geralmente associados a depósitos de sal de cálcio, devido à degeneração de tecido conectivo.

Stenvik e Majör (1970) avaliaram cortes histológicos de dentes removidos por motivos ortodônticos, quando submetidos e não (controle) a um tratamento ortodôntico por um periodo de 4 a 35 dias, onde as forças intrusivas, aplicadas por molas, variaram entre $0,3 \mathrm{~N}$ a $2,5 \mathrm{~N}$. Foram observadas alterações vasculares na porção coronal, vacuolização da membrana odontoblástica e estase vascular pulpar para forças entre $1,5 \mathrm{~N}$ a 2,0 N. Com forças superiores foram observados a destruição de vasos sangüíneos e maior número de capilares na membrana odontoblástica.

Anstendig e Kronman (1972) avaliaram os incisivos mandibulares em movimento de corpo e movimento de torque em seis cães durante 21 dias. Os animais que sofreram movimento ortodôntico apresentaram as seguintes alterações quando comparados aos animais controle: suprimento sangüineo alterado na polpa, vasos sangüineos constringidos, diminuição de fibroblastos, aumento de fibras colágenas, extravasamento de células vermelhas, aumento de células inflamatórias e ruptura da camada odontoblástica.

Hamersky et al. (1980) avaliaram a taxa de respiração, usando a radioespirometria, em pré-molares humanos após a aplicação de forças ortodônticas extrusivas $(1,7 \mathrm{~N})$ durante 72 horas. A radioatividade das polpas coletadas depois da exodontia foi medida, possibilitando inferir que houve diminuição na taxa de respiração nas polpas dos dentes submetidos às forças. Também foi observada pronunciada diminuição na taxa de respiração com o aumento da idade dos individuos. 
Guevara e McClugage (1980) avaliaram polpas de dentes de ratos quando submetidas a forças intrusivas de $0,8 \mathrm{~N}$, usando a microscopia vital. Neste estudo foi observado que em alguns animais a velocidade linear do fluxo sangüíneo nos vasos pulpares mais calibrosos diminuiu significativamente, e noutros houve estase total.

Kvinnsland et al. (1989) avaliaram o fluxo sangüineo da polpa dental e ligamento periodontal utilizando microesferas fluorescentes após a aplicação de forças ortodônticas entre $0,3 \mathrm{~N}$ a $0,5 \mathrm{~N}$, usando molas, em molares de ratos, resultando movimento mesial, por 5 dias. Neste experimento foi observado um aumento do fluxo sangüineo em todas as polpas dos dentes molares estudados. Os autores sugeriram que o aumento de fluxo observado decorreu do aumento de atividade celular durante o processo aposicional e resorptivo.

Vandevska-Radunovic et al. (1994) avaliaram os efeitos de forças ortodônticas de $0,5 \mathrm{~N}$ (usando uma mola ancorada nos incisivos centrais e primeiro molar) sobre o fluxo sangüineo oral de ratos jovens. Foram realizadas injeções de microesferas fluorescentes nos dias 1, 3, 7, 14 e 21 nos animais experimentais e em um grupo controle que não recebeu tratamento ortodôntico. Molares homólogos aos submetidos ao esforço de cada animal também foram usados como controles. No lado experimental foi observada diminuição (estatisticamente não significativa) no número de microesferas no ligamento periodontal, polpa e osso alveolar dos primeiros e segundos molares no primeiro dia depois de aplicadas as forças, quando comparados aos contralaterais. Houve um aumento no número de microesferas no periodonto, polpa e osso alveolar ainda não significativo no terceiro dia, e aumento significativo no sétimo dia no lado experimental do primeiro, segundo e terceiro molar quando comparados ao lado contralateral. Aos 21 dias após aplicadas as forças, os valores dos dois lados aproximam-se. Os autores sugeriram que o aumento de fluxo observado decorreu da rica rede de anastomoses entre osso alveolar e periodonto, e das mudanças na atividade celular necessitando de um maior suprimento de sangue na região.

Sübay et al. (2001) avaliaram cortes histológicos em dentes humanos removidos por razões ortodônticas que foram submetidos a forças de extrusão $(0,75 \mathrm{~N})$. Os autores não encontraram alterações inflamatórias e vasculares significativas nos dois grupos, concluindo que neste estudo forças extrusivas não causaram mudanças patológicas no tecido pulpar humano. 
Barwick e Ramsay (1996), usando a fluxometria laser Doppler, observaram o comportamento do fluxo pulpar sob o efeito de forças intrusivas continuas entre $0,75 \mathrm{~N}$ e 4,5 $\mathrm{N}$ em incisivos centrais permanentes humanos durante 4 minutos em cinco sessões. Na quinta sessão, os autores utilizaram um anestésico vasoconstritor (epinefrina, 1:100.000). Os autores relataram que durante a aplicação da força intrusiva não houve alteração estatisticamente significante no fluxo pulpar (quando as forças intermitentes foram aplicadas), mas quando o anestésico foi administrado o fluxo pulpar caiu drasticamente. Os autores concluiram que o equipamento é sensivel às alterações de fluxo sangüíneo e a razão dos resultados encontrados (ausência de alterações de fluxo com as forças) provavelmente decorreu da pequena quantidade de amostras.

Usando a fluxometria laser Doppler, Brodin et al. (1996) avaliaram o efeito de forças intrusivas e extrusivas em incisivos laterais superiores permanentes de humanos com forças de $2 \mathrm{~N}$ por um periodo de 5 minutos, usando dentes contralaterais como controles. Os autores constataram que houve uma redução do fluxo sangüíneo pulpar durante o movimento de intrusão, mas nāo houve alterações significativas no fluxo pulpar durante o movimento de extrusão.

McDonald e Pitt Ford (1994) avaliaram alterações de fluxo pulpar, via fluxometria laser Doppler, de caninos permanentes superiores humanos antes, durante e depois da aplicação de forças $(0,5 \mathrm{~N})$, produzidas por uma mola de aço ancorada em um aparelho móvel. Este procedimento visou a retração do canino após a exodontia do primeiro pré-molar superior fazendo parte de um tratamento ortodôntico como um todo. Os registros foram realizados antes e imediatamente após a instalação do aparelho, e nos momentos $24 \mathrm{~h}, 48 \mathrm{~h}, 72 \mathrm{~h}$ e $96 \mathrm{~h}$ depois de instaladas as forças. Os autores observaram redução de fluxo sangüíneo pulpar nos primeiros 32 minutos depois de aplicadas as forças, mas nos momentos posteriores investigados, $24 \mathrm{~h}$ e $48 \mathrm{~h}$, o fluxo aumentou, permanecendo acima do valor inicial (antes da força ser aplicada), retornando a valores iniciais em 72 horas. Os registros realizados $96 \mathrm{~h}$ depois de aplicadas as forças foram descartados, decorrente da elevada dispersão de valores nos registros, provavelmente originada de erros no posicionamento da sonda.

Ikawa et al. (2001) avaliaram o efeito de forças intrusivas intermitentes, entre $0,5 \mathrm{~N}$ a $5 \mathrm{~N}$, em incisivos centrais permanentes superiores humanos, durante $20 \mathrm{~s}$, usando a fluxometria laser Doppler. Os autores utilizaram mantas 
protetoras de borracha aplicadas nas gengivas, para minimizar a influência do fluxo gengival (interferência) nos registros. Os autores observaram que houve redução significativa de fluxo sangüíneo pulpar quando as forças intrusivas foram aplicadas em ambas as condições: com e sem a borracha de proteção gengival.

Sano et al. (2002) avaliaram forças intrusivas contínuas de $0,5 \mathrm{~N}, 1 \mathrm{~N}$ e $2 \mathrm{~N}$ em incisivos centrais superiores permanentes humanos, usando a fluxometria laser Doppler. Bráquetes foram colados em primeiros molares superiores e em incisivos centrais superiores. As medidas foram realizadas antes da instalação do fio em quatro sessōes, com o fio em posição (aplicando força) durante um periodo de 6 dias (resultando registros nos dias 1,2, 3 e 6 durante a aplicação das forças), e depois da remoção do fio nos dias 1, 3 e 5 . Noutro grupo foram aplicadas forças intrusivas intermitentes, com magnitudes de $0,5 \mathrm{~N}, 1 \mathrm{~N}$ e $2 \mathrm{~N}$ durante 20 a $30 \mathrm{~s}$. Os autores observaram redução significativa do fluxo sangüíneo pulpar durante a aplicação de forças e retorno ao nivel basal depois de cessadas as forças tanto contínuas como as intermitentes.

Pode ser verificado na exposição acima que os primeiros estudos sobre as alterações do fluxo pulpar decorrentes de movimentos ortodônticos foram estruturados em observações qualitativas das alterações constatadas. Mais recentemente novas técnicas permitiram estimar quantitativamente alteraçōes do fluxo pulpar. Buscando sintetizar a exposição acima sobre as alterações quantitativas expostas, a TAB. 3.1 expressa os principais resultados encontrados $e$ as principais condições dos experimentos. 
TABELA 3.1: Síntese das variações de fluxos pulpares observadas quando dentes humanos ou de animais foram submetidos a movimentos de corpo ( $T$ de tipping) e de intrusão (I), usando as seguintes técnicas quantitativas: microesferas fluorescentes (MEF), fluxometria laser Doppler (FLD). As setas $\uparrow, \rightarrow \mathrm{e} \downarrow$ simbolizam aumento, manutenção e decréscimo de fluxo respectivamente.

\begin{tabular}{|c|c|c|c|c|c|c|c|c|c|}
\hline \multirow[t]{2}{*}{ Autores } & \multirow[t]{2}{*}{ Ano } & \multirow[t]{2}{*}{ Força-Tipo } & \multirow[t]{2}{*}{ Espécie } & \multirow{2}{*}{$\begin{array}{c}\text { Técnica } \\
\text { de } \\
\text { Medição }\end{array}$} & \multicolumn{5}{|c|}{$\begin{array}{c}\text { Fluxo Pulpar } \\
\text { dia }\end{array}$} \\
\hline & & & & & $\overline{1}$ & 3 & 7 & 14 & $\overline{21}$ \\
\hline Vandevska-Radunovic et al. & 1994 & $0,5-\mathrm{T}$ & Rato & MEF & $\rightarrow$ & $\rightarrow$ & $\uparrow$ & $\rightarrow$ & $\rightarrow$ \\
\hline McDonald e Pitt Ford & 1994 & $0,5-T$ & Humana & FLD & $\downarrow \uparrow$ & $\rightarrow$ & $x$ & $x$ & $x$ \\
\hline Brodin et al. & 1996 & $2-1$ & Humana & FLD & $\downarrow$ & $x$ & $x$ & $x$ & $x$ \\
\hline Barwick e Ramsay & 1996 & $(0,05 a 5)-1$ & Humana & FLD & $\rightarrow$ & $x$ & $x$ & $x$ & $x$ \\
\hline Ikawa et al. & 2001 & $(0,5-5)-I$ & Humana & FLD & $\downarrow$ & $x$ & $x$ & $x$ & $x$ \\
\hline Sano et al. & 2002 & $(0,5-2)-1$ & Humana & FLD & $\downarrow$ & $\downarrow$ & $\downarrow$ & $\rightarrow$ & $\rightarrow$ \\
\hline
\end{tabular}

\subsection{Princípios de funcionamento, caracteristicas e limitações da fluxometria Laser Doppler}

O fluxômetro laser Doppler (FLD), quando destinado ao estudo da microcirculação, geralmente usa uma fibra óptica para guiar a radiação laser até o sítio a ser investigado e outra fibra coleta a radiação espalhada pelo tecido investigado e a guia até o instrumento. Usualmente a radiação é gerada por um laser de HeNe (Hélio-Neônio), emitindo em 632,8 nm (radiação visível), ou diodos laser, emitindo entre $780 \mathrm{~nm}$ a $820 \mathrm{~nm}$ (infravermelho próximo), com potências entre $1 \mathrm{~mW}$ a $3 \mathrm{~mW}$. A FIG. 3.1 mostra um FLD (moorLab, Moor Instruments Incorporated, U.K.) e a FIG. 3.2 mostra uma sonda desenhada para mediçōes de fluxo pulpar em dentes anteriores. A sonda (DP13, Moor Instruments Incorporated, U.K.) é composta por duas fibras ópticas com diâmetros de 0,25 $\mathrm{mm}$ com 0,5 mm de espaçamento, conforme mostra a FIG. 3.2.

Ao incidir tecidos biológicos, parte da radiação laser é refletida e parte é transmitida. A radiação transmitida é espalhada e absorvida pela matriz tecidual. $\mathrm{Em}$ tecidos moles não transparentes, geralmente a radiação é tão fortemente espalhada, que após penetrar algumas centenas de micrometros é praticamente 
omnidirecional. A radiação difusa, ao atingir um plexo microvascular, é espalhada pelas células sangüíneas (principalmente pelas hemácias). Quando 0 espalhamento ocorre em um alvo móvel (hemácia), ocorre uma alteração no comprimento de onda da radiação. Esta alteração é proporcional à velocidade do alvo móvel, seguindo os princípios do efeito Doppler. Parte da radiação espalhada pelas hemácias faz o caminho inverso até atingir outra fibra óptica coletora, próxima à que irradia. A radiação coletada é composta por contribuições da radiação espalhada por tecido estático e móvel (hemácias), resultando, na superfície de um detector no instrumento, a somatória dos campos elétricos. 0 detector no instrumento é sensivel apenas à diferença entre as freqüências das radiações espalhadas por alvos móveis e estáticos, convertendo a radiação óptica coletada em um sinal elétrico, denominado fotocorrente. O sinal de fotocorrente é processado no instrumento, para extrair informações sobre o fluxo sangüíneo.

O sinal de fotocorrente tem uma parcela de corrente constante (CC) proporcional à intensidade da radiação total retro-espalhada e uma parcela de corrente alternante $(A C)$ proporcional à radiação retro-espalhada pelas hemácias.

Quando há apenas um alvo móvel, a freqüência da parcela $A C$ da fotocorrente é proporcional à velocidade do alvo móvel. Mas normalmente no volume ao qual o instrumento é sensivel (aproximadamente $1 \mathrm{~mm}^{3}$ em tecidos moles) há dezenas de milhares de hemácias, com velocidades, direções $e$ sentidos diferentes. Como resultado, a parcela $A C$ da fotocorrente não tem uma freqüência única, mas sim uma distribuiçāo com freqüências entre aproximadamente $0 \mathrm{~Hz}$ a $30 \mathrm{kHz}$, não linearmente relacionadas com a distribuição das velocidades das hemácias. Mas os FLDs comerciais calculam uma quantidade $(V)$ proporcional à velocidade eficaz das hemácias, Bonner e Nossal (1981). Velocidade eficaz significa a velocidade média quadrática, i. e., a raiz quadrada da média do quadrado das velocidades.

Os FLDs comerciais também calculam uma quantidade (C), denominada concentração, proporcional à concentração de hemácias contidas no volume ao qual o instrumento é sensivel. Os FLDs comerciais indicam ainda uma quantidade denominada fluxo sangüineo $(F)$ em função do tempo, proporcional ao produto da velocidade eficaz e concentração de hemácias. Ou seja, $F=V \cdot C$. Mas tal relação linear somente é válida quando a concentração de hemácias é pequena (menor que 1\% volume/volume). Quando a concentração de hemácias é 
maior que $1 \%$ vol./vol, há uma relação não linear entre $\mathrm{F}$ e a velocidade eficaz das hemácias: modelos matemáticos prevêem que $F$ aumenta com a raiz quadrada de C. Bonner e Nossal (1981). Mas FLDs comerciais normalmente possuem processadores que tornam linear a relação entre $\mathrm{F}$ e $\mathrm{C}$ (linearizadores), Nilsson (1984).

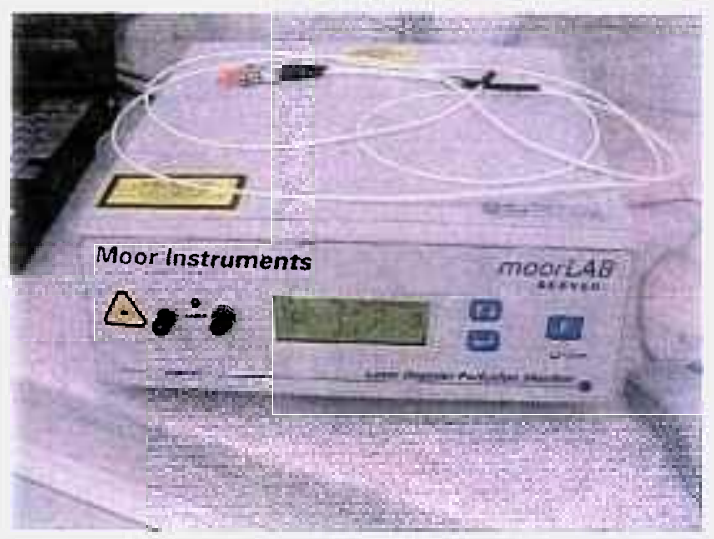

FIGURA 3.1: Fluxômetro moorLab, Moor Instruments Incorporated.
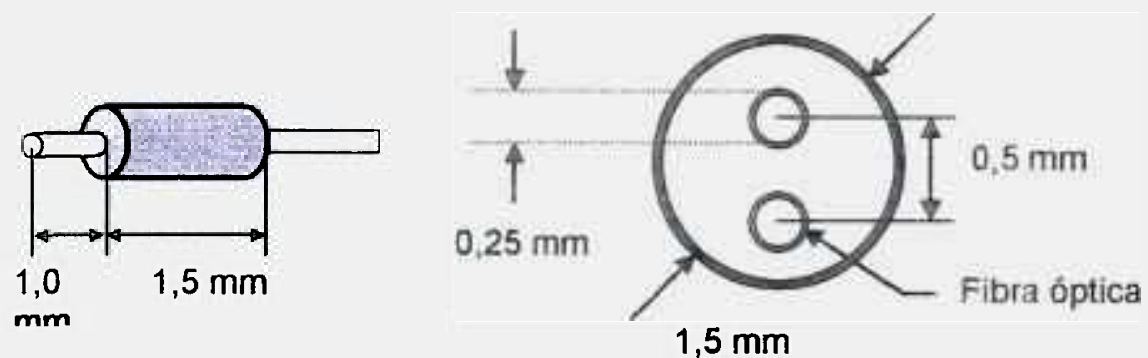

FIGURA 3.2: Sonda DP13, Moor Instruments Incorporated à esquerda e desenho à direita mostrando as fibras receptora e emissora, localizadas na extremidade da sonda

Como um exemplo, para baixas concentrações de hemácias, o fluxômetro moorLab, acima citado, processa o sinal detectado seguindo a fórmula:

$$
F=k \cdot \frac{\int_{f 2}^{n} f \cdot S(f) d f}{\left(I_{C C}\right)^{2}}-\text { ruído }
$$


onde $k$ é uma constante do instrumento, $S(f)$ é a densidade espectral de potência da parcela alternante $(A C)$ do sinal de fotocorrente detectado no instrumento, f1 e f2 delimitam a faixa de freqüências do espectro do sinal Doppler (f2-f1 é a banda Doppler), $I_{C C}$ é a parcela $C C$ da fotocorrente, que é proporcional à potência total da radiação retro-espalhada, Nilsson (1984). O primeiro momento do espectro do sinal Doppler é normalizado pela parcela CC da fotocorrente para corrigir as variações da intensidade da radiação retro-espalhada, decorrentes de variações na intensidade do laser, diferenças de cor de pele e diferenças no ângulo de irradiação. A freqüência $f 1$ normalmente é fixada entre 20 a $40 \mathrm{~Hz}$, e tem a finalidade de minimizar as variações (não Doppler) intensas da parcela $A C$ decorrentes das variações dos caminhos ópticos da radiação retro-espalhada em função do ciclo cardiaco (efeito pletismógrafo). A freqüência f2 delimita a faixa Doppler: i) $15 \mathrm{kHz}$ para medir velocidades até aproximadamente $7 \mathrm{~mm} / \mathrm{s}$; ii) $3 \mathrm{kHz}$ quando a relação sinal/ruído é ótima para medir velocidades de até aproximadamente $1 \mathrm{~mm} / \mathrm{s}$ e; iii) $22 \mathrm{kHz}$ para velocidades de até $10 \mathrm{~mm} / \mathrm{s}$ (valores típicos para um laser operando em $780 \mathrm{~nm}$ ). A parcela "ruído" refere-se à parcela de ruido do sinal Doppler (ruídos dos circuitos eletrônicos do instrumento e do laser).

F, V e C são medidos num volume que depende, dentre outros fatores, das caracteristicas das fibras ópticas emissora e coletora, da separação entre elas, da potência e comprimento de onda do laser, das características ópticas do tecido e da sensibilidade do instrumento. Uma vez que geralmente um ou mais dos fatores acima são desconhecidos, o volume normalmente é desconhecido. Assim medições quantitativas com o FLD geralmente não são possiveis, enquanto variações de fluxo são mensuráveis. Tem sido sugerida a calibragem da quantidade de fluxo em Unidades Arbitrárias (UA), usando um modelo de fluxo padrão (apud Odor et al., 1996). Neste modelo, micro-esferas de aproximadamente $0,5 \mu \mathrm{m}$ de diâmetro suspensas num meio líquido a $25^{\circ} \mathrm{C}$ em movimento browniano resultam um fluxo de 250 UA. Na prática, os FLDs comerciais são calibrados medindo o fluxo de um padrão de calibragem, e ajustando $F$ para indicar 250 UA.

Considerando as potências, comprimentos de onda e fibras normalmente usadas em FLDs comerciais, o instrumento é sensivel a um volume e uma profundidade de aproximadamente $1 \mathrm{~mm}^{3}$ e $1 \mathrm{~mm}$ respectivamente, em tecidos 
moles (exceto em certos tecidos oculares, que são transparentes a radiações entre $400 \mathrm{~nm}$ e $1400 \mathrm{~nm}$ ).

A polpa dentária pode distar vários milimetros da superficie do esmalte. Ainda assim tem sido demonstrado que o FLD é sensivel ao fluxo pulpar. Uma explicação a este fato é a possibilidade de os túbulos dentinários funcionarem como guias ópticos da radiação, Odor et al., 1996b. Outra explicação possivel ao fato de uma fração significativa da radiação atingir a polpa, é o fato de o esmalte e a dentina absorverem pouco a radiação laser na faixa em que os FLDs operam, Farhat, 2003. Mas a radiaçāo laser é espalhada pelo esmalte e dentina, e atinge outros tecidos além da polpa. Tem sido sugerido que uma parcela significativa da radiação atinge o ligamento peridental e gengiva, interage com estes tecidos $e$ retorna à sonda contaminando o sinal do fluxo pulpar. Tem sido sugerido que uma fração de aproximadamente $70 \%$ de $\mathrm{F}$ medido num dente intacto origina de outras regiōes, e não da polpa, Hartmann et al., 1996, Soo-ampon et al., 2003, Akpinar et al., 2004. Mas, conforme é tratado adiante, as frações de fluxo pulpar e não pulpar dependem de muitos fatores, entre os quais, a faixa Doppler do instrumento, características da sonda, suporte de fixaçāo da sonda e comprimento de onda do laser.

O FLD mede velocidades muito baixas, na ordem de $0,01 \mathrm{~mm} / \mathrm{s}$ até 10 $\mathrm{mm} / \mathrm{s}$. Assim qualquer movimento entre a sonda e o dente perturba a medição. Pequenos movimentos da musculatura facial, da respiração ou da própria fibra óptica resultam grandes desvios num registro de fluxo pulpar (Odor et al., 1996c). Assim, tem sido comum fixar a sonda aos dentes usando um suporte mecânico. Suportes de fixação têm sido confeccionados usando silicone (e. g., Odor et al., 1996c), poliuretano (Hartmann et al., 1996), acrílico (Soo-ampon et al., 2003) e discos plásticos fixados diretamente no esmalte (Sano et al. 2002). Os suportes de silicone, acrílico e poliuretano são confeccionados envolvendo a porção anterior e posterior não somente do dente investigado como também de dentes adjacentes, conforme ilustra a FIG. 3.3, objetivando maior estabilidade mecânica. As características ópticas dos materiais usados na confecção dos suportes são variadas, desde opacos até transparentes.

Acredita-se que uma fração da radiação laser refletida no esmalte atinge a gengiva e até a mucosa oral, retornando à sonda, Hartmann et al., 1996 e Sooampon et al., 2003. Assim, tem sido sugerida a blindagem óptica da gengiva 
objetivando minimizar a interferência gengival. As blindagens já avaliadas foram mantas opacas de látex (Hartmann et al., 1996 e Soo-ampon et al., 2003), manta de liga metálica (Hartmann et al., 1996) ou resina opaca (Akpinar et al. 2004), mas sempre associadas a suportes rígidos. Como um exemplo, um arranjo constituido por um suporte rígido e transparente de poliuretano e uma manta opaca de látex isolando a gengiva reduz o fluxo medido a $30 \%$ (valor médio, $\mathrm{n}=23$ ) do valor de fluxo medido com o mesmo arranjo sem a manta de látex (Hartmann et al., 1996). No entanto a banda Doppler foi fixada em $15 \mathrm{kHz}$, e a sonda posicionada a $3 \mathrm{~mm}$ da margem gengival (outra banda Doppler e ou outra distância pode resultar outra fração). Não foram encontrados, na literatura, estudos sobre o efeito do isolamento óptico quando associado a suportes de silicone não rígidos e não transparentes.

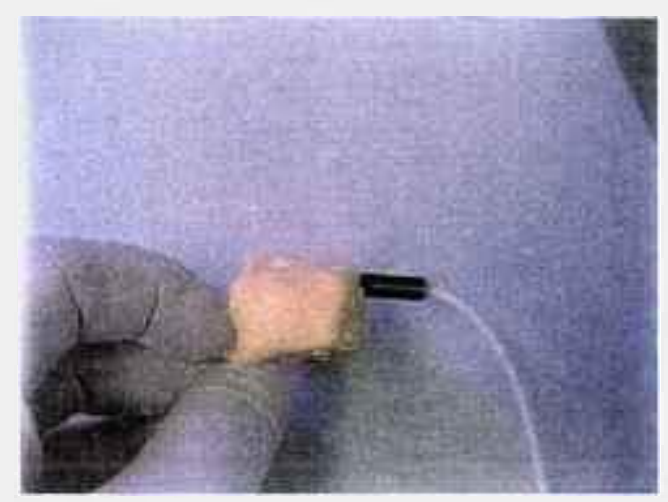

Figura 3.3: Suporte de silicone destinado à estabilização de sonda de um FLD.

Vários estudos sugerem que a quantidade $F$ medida em dentes intactos depende do comprimento de onda do laser, da banda Doppler, do espaçamento entre as fibras ópticas que compõem a sonda e da posição da sonda no dente. Embora nem todas as explicações para tais dependências sejam comprovadas, muitas conjecturas foram suscitadas na literatura.

Os primeiros FLDs comerciais eram equipados com lasers de $\mathrm{HeNe}$, emitindo em $632,8 \mathrm{~nm}$. Mas com a difusão do uso de diodos laser, com dimensões e custo sensivelmente menores, os FLD atuais usam diodos laser emitindo entre $780 \mathrm{~nm}$ a $820 \mathrm{~nm}$.

Foi especulado que radiações com comprimentos de onda maiores (780 $\mathrm{nm}$ ) penetram mais profundamente na polpa quando comparadas com a do HeNe 
(Odor et al., 1996c). O fato é que o valor de $\mathrm{F}$ é maior quando o laser opera em $780 \mathrm{~nm}$, quando comparado ao valor de $\mathrm{F}$ medido com laser emitindo em 632,8 $\mathrm{nm}$ (Odor et al., 1996c, Roebuck et al., 2000). Argumenta-se que este fato decorre da maior penetração da radiação. Assim vasos com maiores calibres, situados no centro da polpa são irradiados, enquanto comprimentos de onda menores não penetram na polpa (Odor et al., 1996c). No entanto não foram encontrados na literatura estudos rigorosos demonstrando diferença significativa da penetração da radiação na faixa entre $632,8 \mathrm{~nm}$ a $820 \mathrm{~nm}$.

A banda Doppler delimita a faixa de velocidades mensuráveis. Tem sido sugerido o uso da banda Doppler estreita ( $3 \mathrm{KHz}$ ou $4 \mathrm{kHz}$ ) objetivando minimizar a interferência periodontal no fluxo medido. O argumento é que os calibres dos vasos sangüineos na gengiva e região peridental são maiores que os encontrados na polpa. Em vasos maiores geralmente ocorrem velocidades de fluxo maiores. Assim uma banda Doppler pequena minimiza interferências (Mesaros et al., 1997). O fato é que a diferença entre fluxos de dentes saudáveis e desvitalizados é maior quando a banda Doppler é $3 \mathrm{kHz}$ ou $4 \mathrm{kHz}$, quando comparada com a obtida com bandas maiores (Odor et al. 1996a e Roebuck et al., 2000). Note-se que uma vez que em dentes desvitalizados o fluxo pulpar é nulo, e que o fluxo $F$ medido em um dente desvitalizado (via FLD) não é nulo: nestas condições $F$ medido origina de outras regiōes (Odor et al. 1996b e Roebuck et al., 2000). Assim uma maior diferença significa menor contaminação do fluxo medido.

Tem sido demonstrado que a separação entre as fibras na sonda influencia 0 valor de $F$ medido. Vários desenhos de sonda foram testados, usando fibras com diâmetros entre $0,125 \mathrm{~mm}$ a $0,25 \mathrm{~mm}$, espaçadas deste $0,25 \mathrm{~mm}$ até 1,5 $\mathrm{mm}$. Maiores espaçamentos resultaram maiores valores de $F$, sendo especulado que um maior espaçamento significa um maior volume sensivel, onde mais vasos são irradiados (Ingolfsson et al., 1993). Mas estudos posteriores sugerem que menores espaçamentos $(0,25 \mathrm{~mm}$ a $0,5 \mathrm{~mm})$, embora resultem sinais menores, resultam maiores diferenças entre valores de $F$ de dentes vitalizados $e$ desvitalizados (Roebuck et al., 2000). Acredita-se que isto ocorre porque um espaçamento menor significa um volume irradiado menor e conseqüentemente menor contaminação de fluxo não pulpar.

Quanto mais próxima a sonda da gengiva, maior o valor de $\mathrm{F}$ medido, quando o espaçamento entre fibras é pequeno. No entanto sondas com fibras 
mais espaçadas resultam menor sensibilidade da posição da sonda no dente. Ou seja, o valor de F varia pouco com a localização da sonda no dente (Ingolfsson et al., 1994). Uma explicação possivel a este fato é que a polpa é a maior região próxima à gengiva (Ingolfsson et al. 1993). Mas enquanto o valor de F cresce com a aproximação da sonda na direção da gengiva, especula-se que é maior a contaminação de $F$ pela gengiva e periodonto. $O$ oposto também tem sido observado: o valor de F diminui quando a sonda é afastada da gengiva, assim como é especulado que é menor a contaminação peridental e gengival. Buscando saber qual é o melhor comprimento entre a distância da sonda da margem gengival, foi observado que a sonda localizada entre 2 a $3 \mathrm{~mm}$ da margem gengival, com uma sonda com espaçamento de $0,5 \mathrm{~mm}$ (entre fibras), banda Doppler de $3 \mathrm{kHz}$ e laser emitindo em $632,8 \mathrm{~nm}$ resulta a maior diferença entre fluxos de dentes vitalizados e desvitalizados (Roebuck et al., 2000). No entanto Odor et al. (1996b) observaram maior diferença entre fluxos de dentes vitalizados e desvitalizados com o comprimento de onda de $810 \mathrm{~nm}$, quando comparada com a diferença obtida com o laser emitindo em $632,8 \mathrm{~nm}$, usando uma única sonda com espaçamento de $0,25 \mathrm{~mm}$, e banda Doppler ajustada em $3 \mathrm{kHz}$, pois bandas Doppler maiores resultaram menores diferenças entre fluxos.

$O$ fluxo $\mathrm{F}$ de dentes anteriores saudáveis e intactos, medido com um FLD, apresenta pequenas Variações Rápidas de Fluxo (VRF), seguindo o ciclo cardiaco (60 a 80 ciclos por minuto), conforme mostra o gráfico na FIG. 3.4, e pequenas Variaçōes Lentas de Fluxo (VLF), que ocorrem com freqüência entre 1 a 10 ciclos por minuto, decorrentes de processos fisiológicos de regulagem do fluxo (vasomotilidade), também mostradas no gráfico da FIG. 3.4. Foi sugerido que tais variações de $\mathrm{F}$ sejam oriundas majoritariamente da polpa (ver Odor et al., 1996b para VRF e Evans et al., 1999. para VLF). Note-se que o registro de F apresenta VLF com flutuações elevadas (aproximadamente 30\% de seu valor médio). Assim é comum medir o fluxo médio num intervalo suficientemente longo. 


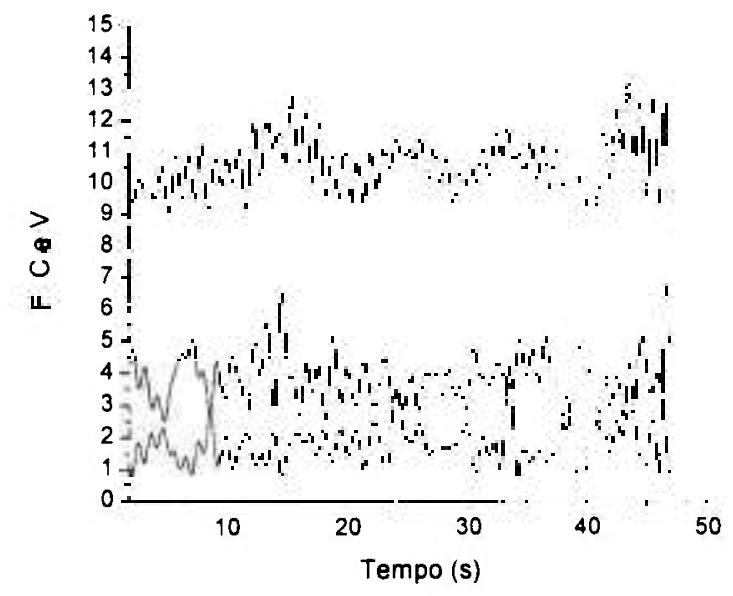

FIGURA 3.4: Registros de Fluxo (superior), Concentração (intermediário) e Velocidade (inferior) de um incisivo central saudável. No registro de fluxo, as variações rápidas seguem o ritmo cardíaco e as lentas (note a envoltória), seguem a vasomotilidade dos microvasos.

$\mathrm{Na}$ literatura relacionada, a maior parte dos estudos do fluxo pulpar com o FLD em dentes intactos avalia o parâmetro fluxo $F$ de cada indivíduo. Mas o valor de $F$ apresenta elevada variabilidade entre dentes do mesmo individuo (e. g., Ingolfsson et al., 1993) e entre indivíduos (Nogueira, 2003). A variabilidade decorre provavelmente de vários fatores: variaçōes individuais das características ópticas do dente, da forma e volume da polpa, dentina e esmalte, da gengiva e região peridental, variações no fluxo sistêmico, posição do paciente, estado emocional, idade entre outros (Nogueira, 2003). Em adição, erros na medição (posicionamento da sonda, calibragem do instrumento, variações na responsividade da sonda e instrumento, e outros) contribuem. O fato é que é possivel controlar e minimizar alguns fatores: como exemplos, a calibragem do FLD, o posicionamento, a posição do paciente, a pressão sistêmica, o uso de medicamentos e a temperatura ambiente. Mas outros não são previsiveis ou controláveis. Como exemplos, variações individuais do fluxo, das caracteristicas ópticas e da forma do dente e região próxima, e da resposta neurovascular. Ainda assim, em todos os trabalhos citados previamente nesta subsecção, exceto o de Nogueira (2003) e Roebuck et al. (2000), um valor médio de $\mathrm{F}$ de um número finito de indivíduos é tomado como controle. Roebuck et al. (2000) avaliaram a razão entre fluxos de dentes saudáveis e desvitalizados do mesmo indivíduo, não 
necessariamente homólogos. Mas os autores não exploraram a menor variabilidade deste novo parâmetro (razão entre fluxos). Sano et al. (2002) avaliaram variações do fluxo pulpar decorrente da aplicação de forças mecânicas, tomando como referência (controle) o próprio individuo. Mas os autores também não comentaram e não exploraram as vantagens deste método, focando a menor variabilidade da variação percentual de fluxo, quando comparada com a variabilidade do valor médio de fluxo.

O uso da variação percentual de fluxo entre dentes homólogos como parâmetro hemodinâmico (e não o valor médio de $F$ ) foi recentemente explorado por Nogueira (2003) e Eduardo (2004), e a variaçāo percentual entre dentes decíduos adjacentes também foi explorada recentemente por Wanderley (2004), sendo todos os trabalhos oriundos de um programa conjunto ao qual este trabalho também esteve inserido ${ }^{1}$. 


\section{MATERIAIS E MÉTODOS}

Foram selecionados voluntários assistidos pelo curso de especialização em Ortodontia, da Sociedade Paulista de Ortodontia e Ortopedia Facial, que apresentavam maloclusões pertencentes à Classe II Divisão 1 de Angle. A escolha do grupo, Classe II de Angle, deve-se ao fato de sua alta incidência, que é de $42 \%$ da população (Da Silva Filho et al., 1990). A escolha do incisivo central decorre da alta freqüência de casos de reabsorção encontrados neste dente após tratamentos ortodônticos, quando comparado à de outros dentes (Morse,1971).

O grupo inicialmente selecionado com as características acima foi composto por 23 individuos de ambos os sexos, e subdivididos em dois grupos: i) 12 individuos na primeira fase (nivelamento) com idades entre 12 a 23 anos, idade média de 17,5 anos; ii) 13 indivíduos na segunda fase (retração) com idades entre 14 e 40 anos, idade média de 19,6 anos, todos apresentando ápices radiculares formados. Os indivíduos selecionados apresentavam seus incisivos centrais superiores esquerdos higidos, sem histórico de trauma e gengivas sadias. Os dentes foram considerados saudáveis quando estavam livres de cáries, restauraçōes, defeitos no esmalte, atrição, descoloração e a gengiva apresentava ausência de qualquer alteração visual. Foram realizadas radiografias periapicais nos dentes estudados.

A cada voluntário foi solicitado que relatasse o uso de medicações durante toda a fase que esteve sujeito ao monitoramento do fluxo. Todas as medições foram realizadas após um periodo mínimo de 30 minutos depois da chegada à clínica. A temperatura ambiente durante todos os registros foi mantida entre $20^{\circ} \mathrm{C}$ a $25^{\circ} \mathrm{C}$. Todos os voluntários permaneceram sentados e imóveis durante os registros. Este trabalho foi aprovado pelo Comitê de Ética em Pesquisa do Ipen.

O procedimento planejado para o tratamento ortodôntico foi a extração dos primeiros pré-molares superiores, direito e esquerdo, e dos primeiros pré-molares inferiores direito e esquerdo. Após as extrações, o tratamento envolveu duas fases distintas: i) o nivelamento, quando ocorreu a nivelação dentária; ii) a retração, quando os dentes incisivos e caninos foram transladados, ocupando o 
espaço do pré-molar extraído. Um resumo dos movimentos estudados e das características dos materiais dos aparelhos é apresentado no ANEXO A.

Dos vinte e três voluntários, em ambas as fases, subgrupos de dois a três individuos iniciaram seus tratamentos em momentos diferentes, viabilizando o acompanhamento de doze individuos na primeira fase (nivelamento) e treze na segunda fase (retração). Alguns voluntários participaram das duas fases, e cinco participaram de um estudo sobre a estabilidade dos registros e sobre as frações do sinal Doppler (objetivos e métodos abaixo descritos).

$\mathrm{Na}$ seqüência são descritos os materiais e métodos usados na primeira fase, e as poucas alterações ocorridas durante a segunda fase.

\subsection{Primeira fase: nivelamento}

Na seqüência são descritos os materiais e métodos usados nas duas fases estudadas, destacando que a segunda fase difere da primeira somente quanto ao movimento estudado e momentos investigados.

\subsubsection{Força ortodôntica}

Passado o interstício de 15 dias após as extrações, em cada paciente foi efetuada a passagem, nos bráquetes, de fios GAC NiTi Accuform Sentalloy calibre 0.014 " com amarrilhos de fixação de metal calibre 0.020 ", compondo o aparelho ortodôntico que promove o nivelamento dentário (primeira fase do tratamento). Este arranjo promove a aplicação de forças numa faixa $1,0 \mathrm{~N}$ (dependente da inclinação dos dentes).

Um mês depois de aplicado o fio, promovendo a força ortodôntica, outro fio (eventualmente com outro diâmetro) foi aplicado. Este processo foi repetido até que o nivelamento desejado fosse atingido, num periodo entre 6 a 10 meses (dependeu da evolução de cada paciente). Cada paciente foi monitorado durante os primeiros 30 dias do tratamento.

Subgrupos entre dois a três pacientes iniciam seus tratamentos em momentos diferentes. Durante o período de monitoração a saúde bucal dos pacientes, em particular a da gengiva, foi acompanhada, verificando sinais visiveis de inflamação. 


\subsubsection{Momentos investigados}

Registros de fluxo pulpar usando a FLD foram coletados em cinco sessões nos seguintes estágios do tratamento: i) após a colagem dos bráquetes, sem a passagem do fio inicial; ii) vinte minutos após a passagem do fio; iii) 48 horas após a colocação do fio; iv) 72 horas após a colocação do fio; v) um mês após a colocação do fio.

\subsubsection{Suporte de fixação da sonda}

Para fixar a sonda foram confeccionadas impressões de silicone, usando material de moldagem Vision A. S. T. (Degussa Dental, Alemanha), FIG. 4.1 (a), seguindo o processo descrito por Olgart et al. (1988), Gazileus et al. (1988), McDonald e Pitt Ford (1994), Nogueira (2003), Wanderley (2004) e Eduardo (2004). O silicone foi aplicado a uma moldeira parcial para a região anterior superior, inclinando-se a parte posterior da moldeira no sentido lingual para obter maior quantidade de material na região vestibular dos dentes incisivos no ato da moldagem, permitindo a fixação da sonda, conforme mostrado na FIG. 4.1 (b). Sobre os bráquetes já fixados, FIG. 4.1 (c), foi aplicada uma barra de cera periférica da marca Kota (Kota Indústria e Comércio LTDA., São Paulo, Indústria Brasileira) na região dos incisivos laterais e centrais superiores direito e esquerdo, FIG. 4.1 (d), com o objetivo de promover alivio das áreas retentivas no processo de moldagem.

Após a remoção do molde, FIG. 4.1 (e), a posição do bráquete do incisivo central superior esquerdo foi visualizada na marca da cera. O posicionamento da sonda foi efetuado tomando como referência esta marca na cera. Ou seja, o posicionamento da sonda no dente foi efetuado tomando como referência o bráquete, que é rigidamente unido ao esmalte dental. Assim, a posição da sonda foi mantida entre as sessões, $e$ independeu do movimento dos dentes. A impressão foi perfurada na margem da marca correspondente a posição do bráquete (aproximadamente a $0,75 \mathrm{~mm}$ acima da borda do bráquete) com uma broca de aço rápido com 1,5 mm de diâmetro, FIG. 4.1 ( $f$ ), para a passagem e fixação da sonda, FIG. $4.1(\mathrm{~g})$. Após a perfuração, a sonda foi inserida no molde de silicone, de vestibular para lingual, observando-se não haver nenhum material 
sobre a ponta desta. O molde foi levado à cavidade bucal e testada sua fixação quanto a possiveis movimentos de báscula indesejados. FIG. 4.1 (h). O paciente manteve-se relaxado e imóvel durante o registro (1 minuto), prevenindo artefatos nos registros.

\subsubsection{Fluxômetro Laser Doppler}

Os registros de fluxo foram efetuados com um fluxômetro moorLab (Moor Instruments Incorporated, Axminster, UK), equipado com um laser diodo que emite no infravermelho, no comprimento de onda $780 \mathrm{~nm}$. O fluxômetro laser Doppler é um laser de baixa intensidade (aproximadamente $1 \mathrm{~mW}$ ), classificado pelo fabricante como pertencente à Classe $3 A$ (Norma IEC 60825-1).

A sonda usada foi a DP13, do mesmo fabricante (FIG. 4.2). A sonda é composta por duas fibras ópticas de $0,25 \mathrm{~mm}$ acondicionadas em um tubo de aço de $1,5 \mathrm{~mm}$.

A largura de banda do sinal Doppler foi ajustada em $3,1 \mathrm{kHz}$ (o equipamento permite a seleção em $3,1 \mathrm{kHz}, 15 \mathrm{kHz}$ e $22 \mathrm{KHz}$ ) objetivando minimizar as interferências provocadas pelo fluxo gengival (Evans et al., 1999).

A sonda usada foi calibrada entre as sessões, usando uma suspensão contendo micro-esferas em movimento browniano. O fluido usado para a calibração foi fornecido pelo fabricante do fluxômetro.

\subsubsection{Registros de fluxo}

Durante cada sessão foram colhidos três registros de fluxo de cada incisivo. Um registro típico é mostrado na FIG. 4.3. Cada registro teve duração média de 1 minuto. Em cada registro foi calculado o valor médio do fluxo durante aproximadamente $5 \mathrm{~s}$ no início, meio e fim do registro, e a média dos três valores foi computada. resultando um valor de fluxo de cada sessão, $F$, em unidades arbitrárias (UA). aqui denominado $F(U A)$. A escolha de registros de 1 minuto decorreu do fato de que ocorrem flutuações ciclicas de fluxo, com períodos entre 1 a 10 minutos (Evans et al., 1999). Assim durante um minuto geralmente ocorre entre um a dez ciclos completos das flutuações, sendo possivel medir o valor médio. 

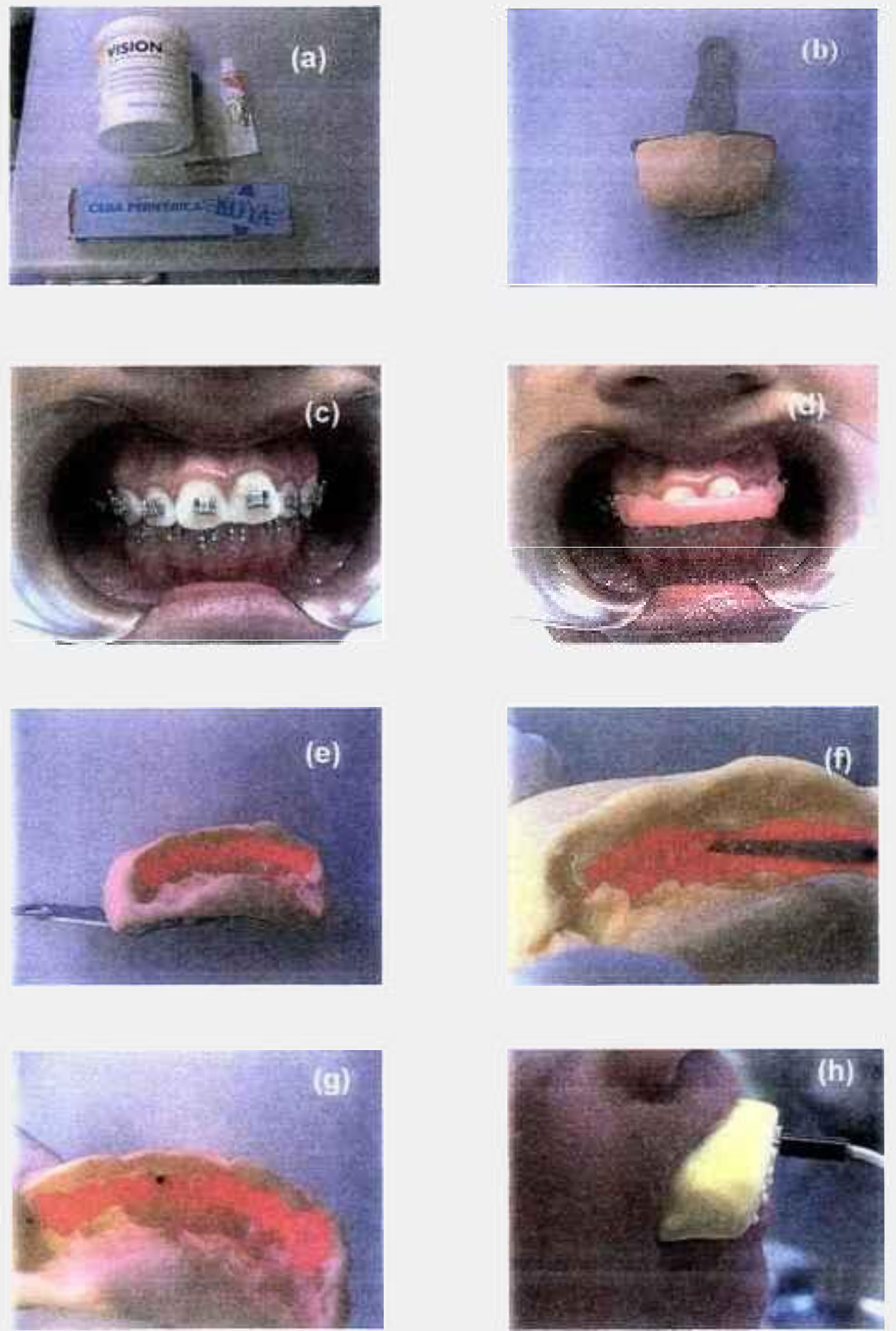

FIGURA 4.1: Processo de confecção do suporte de silicone: (a) silicone; (b) preenchimento do molde com silicone; (c) fixação dos bráquetes; (d) proteção dos bráquetes com cera; (e) suporte moldado; (f) furação do molde com broca na marca do bráquete; (g) furação para passagem da sonda e; (h) sonda fixada. 


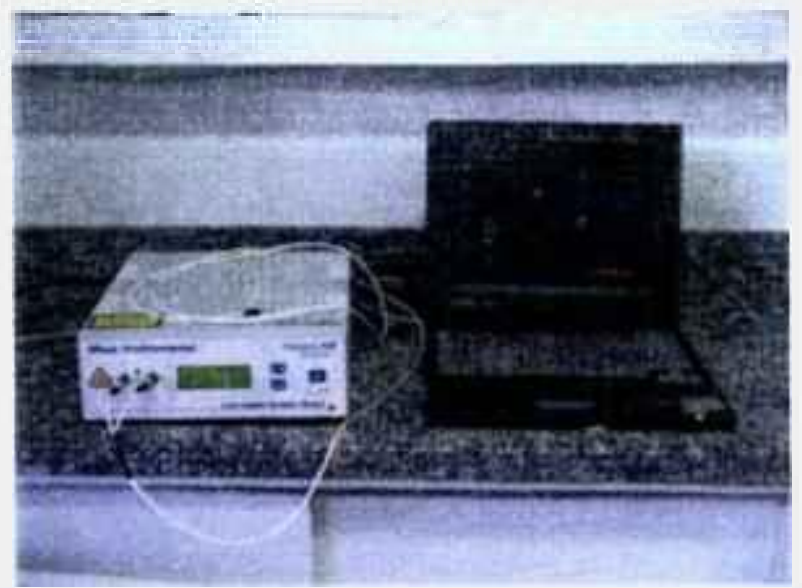

FIGURA 4.2: Fluxômetro Laser Doppler moorLab acoplado a um notebook.

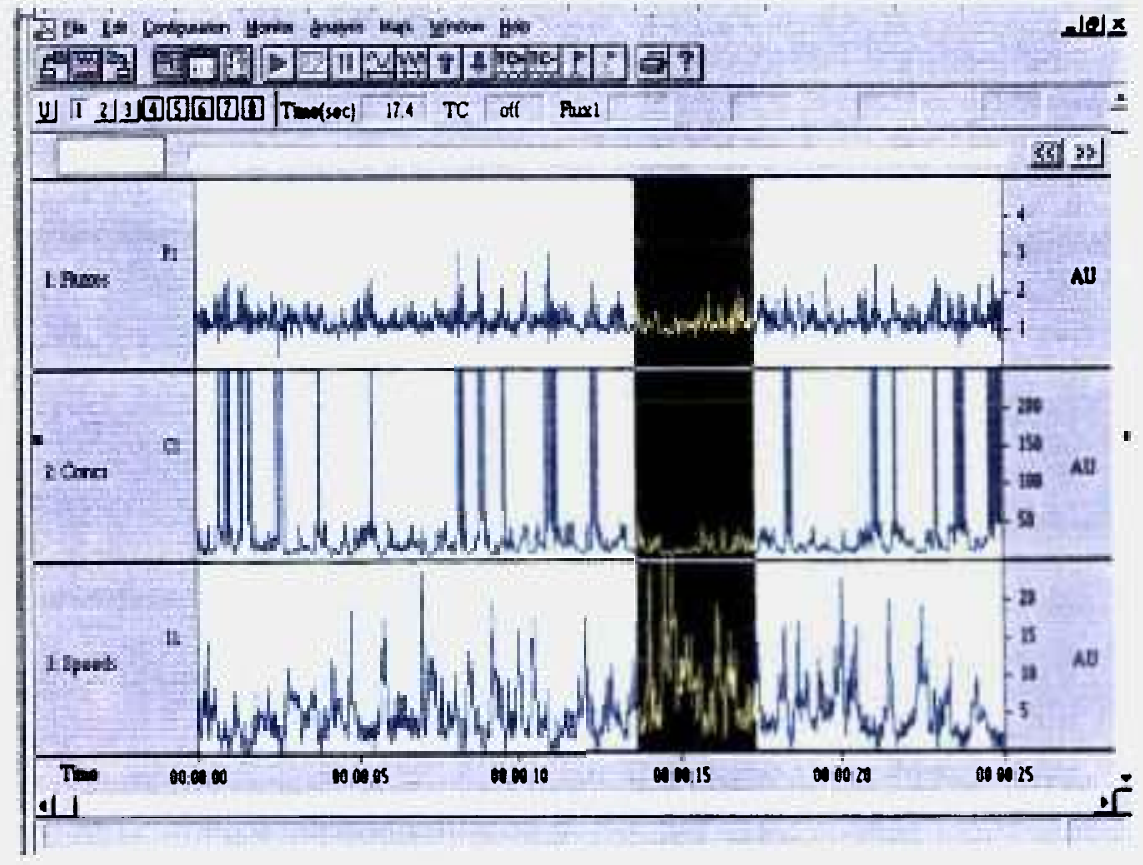

FIGURA 4.3: Registro típico de fluxo (traço superior), concentração de hemácias (traço intermediário) e velocidade de hemácias (traço inferior) de um dente incisivo. 


\subsubsection{Indicadores de variações de fluxo}

As alterações de fluxo devem ser comparadas a uma referência, comumente denominada, na literatura relacionada, controle. Uma prática comum é comparar os valores dos fluxos pulpares de dentes submetidos às forças com os valores de dentes livres de forças (controle), e. g. McDonald e Pitt Ford (1994). Mas, uma vez que há elevadas variações no fluxo pulpar entre individuos, preferimos usar como controle o fluxo de cada indivíduo antes da aplicação da força. Ou seja, neste estudo foi usado como referência o fluxo antes da aplicação da força.

As variações de fluxo de cada sessão e de cada indivíduo foram analisadas usando três parâmetros: $F(U A)$, acima definido, $F(\%)$ e $F($ dif $)$, definidos na seqüência:

$$
F(\%)=\frac{F_{B}}{F_{A}} \bullet 100
$$

onde $F_{A}$ é o valor do fluxo inicial em UA (unidades arbitrárias), e $F_{B}$ são valores de fluxo nas sessões posteriores ( 20 minutos, 48 horas, 72 horas e 1 mês). Assim, $F(\%)$ em cada momento significa a variação percentual de fluxo do momento interrogado em relação ao momento inicial, quando o fluxo está inalterado e

$$
F(\text { dif })=F_{B}-F_{A}
$$

Assim $F$ (dif) significa a diferença entre os fluxos $F$ medidos nos momentos posteriores (20 minutos, 48 horas, 72 horas e 1 mês) e o medido no momento inicial, para cada incisivo.

\subsubsection{Controle e estabilidade dos registros}

As variações de fluxo de cada incisivo e as variações medianas de fluxo do grupo foram analisadas comparando os valores de fluxo, $F(U A)$, durante as sessões investigadas, com os valores de $F(U A)$ no instante inicial, antes da força 
aplicada. $F(\%)$ e $F($ dif) também foram usados para analisar variações e diferenças de fluxo. Mas, de acordo com (4.1) e (4.2), por definição, $F(\%)$ e $F($ diff) também são indicadores que tomam como referência o valor de $F(U A)$ no instante inicial. Assim o controle de $F(U A), F(\%)$ e $F$ (dif) em cada instante é o valor de $F(U A)$ no momento inicial.

$O$ uso de $F(U A)$ de cada individuo num momento inicial como controle é bem estabelecido na literatura da FLD quando é desejado medir variações de fluxo num intervalo curto de tempo (e. g., Heyeraas e Kvinnsland. 1992). Mas quando o periodo de investigação é grande, é necessário avaliar a estabilidade de todo arranjo fluxométrico, incluindo calibragens do instrumento e erros no posicionamento do suporte de fixação da sonda.

Assim, para avaliar a estabilidade das medições no presente estudo, foram medidos os valores de fluxo de cinco incisivos centrais permanentes superiores esquerdos de cinco individuos pertencentes ao grupo inicialmente descrito (23 individuos). As mediçōes foram realizadas em cada indivíduo em duas sessōes: num momento inicial, denominada Inicial, e numa outra sessão um mês após a inicial, aqui denominada 1 mês. Em cada sessão foram realizadas três medições e em cada medição foram medidos três valores de fluxo médios, seguindo a metodologia já descrita anteriormente.

\subsubsection{Frações do sinal Doppler}

No Capitulo 3 foi mencionado que o sinal Doppler medido em um dente intacto contém frações de fluxo de outras regiões além da polpa. Assim é necessário conhecer a parcela de fluxo medido oriunda da polpa, assim como as frações restantes, para que seja possivel interpretar os resultados aqui apresentados. Mas embora a literatura sugira alguns valores de frações, somente são aplicáveis ao suporte de fixação, condições especificas do equipamento (banda Doppler, sonda, calibragem. comprimento de onda do laser), das caracteristicas do suporte de sonda usado e tipo de dente estudado. Para o arranjo fluxométrico usado, e demais condições do estudo, as frações que compõem o sinal medido eram desconhecidas. Assim foi necessário estimar as fraçōes. 
Os valores de fluxo de nove incisivos centrais saudáveis do grupo descrito na subseção anterior foram medidos em duas condições: i) com e; ii) sem uma manta de látex isolando o incisivo investigado, bem como seus dois laterais. $A$ manta, confeccionada com látex de balões (Happy Day Ind. Com. Ltda, São Roque, Brasil) apresentando coloração verde-escura, foi caracterizada como segue. A densidade de potência da radiação emitida pela sonda do instrumento $\left(780 \mathrm{~nm}, 1 \mathrm{~mW}\right.$, divergência de aproximadamente $\left.10^{\circ}\right)$ foi medida antes e após a transmissão pela manta, resultando atenuação igual a 1000. As densidades de potência foram medidas usando um medidor de potência marca Coherent (U.S.A.), modelo FM, com diâmetro do elemento sensivel igual a $7 \mathrm{~mm}$. A distância entre a sonda e o sensor foi inferior a $1 \mathrm{~mm}$, com e sem a manta de látex.

\subsection{Segunda fase: retração}

O estudo do processo de retração (segunda fase) foi realizado no mesmo grupo de voluntários acima descrito.

\subsubsection{Força ortodôntica}

No processo de retração foram aplicados arcos dupla chave. Os arcos foram confeccionados com fios de aço de secção retangular de $0.019^{\prime \prime} \times 0.025$ ", conforme ilustra a FIG. 4.4 .

Durante o processo de retração o movimento dentário predominante é o de corpo: quando os dentes sofrem movimentos de translação. O processo foi iniciado com a ativação dos arcos, quando são distendidos a $1 \mathrm{~mm}$, exercendo uma força média de $2,50 \mathrm{~N}$.

Após um periodo de um mês, quando já ocorreu movimentação dentária (alterando a força exercida pelos arcos), os arcos foram novamente distendidos, iniciando outro ciclo, similar ao primeiro. Esta fase do tratamento terminou entre 6 a 10 meses após iniciada (depende da evolução de cada paciente).

Subgrupos de dois a três pacientes iniciam seus tratamentos em momentos diferentes. Cada paciente foi estudado durante um intervalo de um mês, quando 
os arcos são novamente ativados. Alguns pacientes foram monitorados durante 45 dias, sem ativação do arco neste interstício.

\subsubsection{Momentos investigados e metodologia}

A metodologia utilizada nas medições de fluxo nesta fase foi a mesma descrita para o nivelamento, exceto a adição de uma sessão de registros 45 dias após a aplicação da força. Assim registros foram coletados em seis sessões : i) com o fio retangular em posição sem ativação do arco dupla chave; ii) vinte minutos após a ativação; iii) 48 horas após a ativação; iv) 72 horas após a ativação; v) 1 mês após a ativação; vi) 45 dias após a ativação.

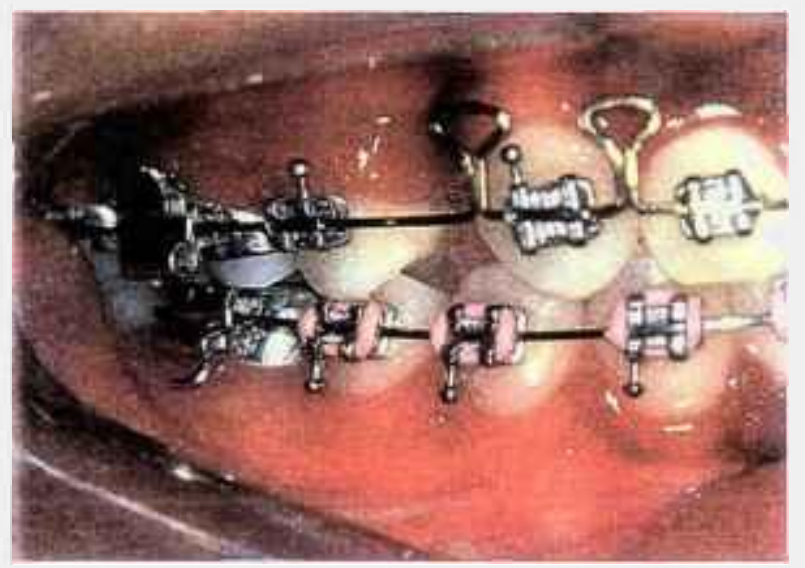

FIGURA 4.4: Aparelho usado durante a fase de retração (arcos de dupla chave). 


\section{RESULTADOS}

As alterações de fluxo registradas durante as duas fases investigadas são apresentadas neste capítulo. Antes, porém, dois tópicos necessários à interpretação dos resultados são apresentados: i) os resultados obtidos de registros de fluxo efetuados separados em intervalos de 1 mês objetivando avaliar a estabilidade de todo arranjo fluxométrico e; ii) resultados sobre um estudo das frações que compõem a quantidade de fluxo medida, oriundas doutras regiões além da polpa.

\subsection{Controle e estabilidade dos registros}

Os valores de fluxo de cinco incisivos medidos em duas sessões (Inicial e 1 mês depois) são apresentados na TAB. 5.1. Na sessão Inicial, o valor mínimo foi de 9,3 UA e o valor máximo foi de 20,4 UA, apresentando valor médio igual a 15,7 UA e desvio-padrão de 5 UA. Na sessão 1 mês, o valor mínimo foi de 9,9 UA e o valor máximo foi de 18,8 UA, com valor médio igual a 14,8 UA e desvio padrão de 4,3 UA. Nota-se a vasta faixa de valores de fluxo em ambas as sessões, mas nota-se que os valores de fluxo de cada individuo entre as sessões variou pouco. Este fato reflete a grande variação de fluxo entre indivíduos, mas os valores de fluxo em cada individuo variou pouco entre as sessões, como era esperado, sugerindo que a variação percentual de fluxo é um parâmetro indicador de alterações de fluxo mais apropriado ao presente estudo, quando comparado ao parâmetro fluxo (em UA). De fato, enquanto o desvio padrão desvia entre $31,8 \%$ a $29 \%$ dos respectivos valores médios em UAs (sessões Inicial e 1 mês), varia somente $9 \%$ em $F(\%)$ (ver TAB. 5.1).

Objetivando verificar se o fluxo mediano na sessão Inicial é diferente do fluxo mediano na sessão 1 mês, foi usado o teste Wilcoxon (Wilcoxon signed-rank test) para duas amostras pareadas resultando evidências estatísticas insuficientes ( ara $p<0,05$ ) para admitir diferença entre as medianas. Para verificar se o valor mediano da variação percentual de fluxo, $F(\%)$, entre as sessões é diferente de 
$100 \%$ (por definição $F(\%)=100 \%$ no inicio), foi empregado o teste Wilcoxon para uma amostra, novamente resultando evidências insuficientes para admitir diferença $(p=0,28)$. Portanto, não há evidências suficientes para inferir que valores medianos de fluxo, $F(U A)$, e de $F(\%)$ nas duas condições sejam diferentes.

O intervalo de confiança (IC) da mediana da variação percentual de fluxo na segunda sessão, estimado usando o método de Wilcoxon, é entre $86,4 \%$ a $105,8 \%$, para $94,1 \%$ de significância, lembrando que o valor da variação percentual de fluxo mediana na primeira sessão é, por definição, $100 \%$.

TABELA 5.1: valores de fluxo de cinco incisivos saudáveis medidos com intervalo de um mês.

\begin{tabular}{lccc}
\hline PacientelMomento & Inicial & 1 mês & $F(\%)$ \\
\hline P1 & 20,4 & 18,1 & 89,1 \\
P2 & 9,3 & 9,9 & 105,8 \\
P3 & 18,3 & 18,8 & 103,2 \\
P4 & 19,3 & 16,6 & 86,4 \\
P5 & 11,3 & 10,5 & 92,8 \\
& & & \\
Mediana & 18,3 & 16,6 & 90,7 \\
Média & 15,7 & 14,8 & 95,5 \\
Desvio Padrão & 5 & 4,3 & 8,6 \\
(Desvio Padrão/Média) $\times 100$ & $31,8 \%$ & $29 \%$ & $9 \%$ \\
\hline
\end{tabular}

O IC da acurácia relativa, aqui definida como o desvio percentual do valor mediano da variação percentual de fluxo, quando o desvio decorreu entre as duas sessões, é de $-13,6 \%$ a $5,8 \%$ para $94,1 \%$ de significância. Aqui a acurácia relativa significa a estabilidade das medições. Ou seja, tomando como referência o fluxo no instante inicial, a acurácia relativa é um indicador da incerteza das medições realizadas um mês depois, levando em conta desvios do instrumento e do fluxo, quando todas as condições possiveis de serem controladas foram controladas (e. g., calibragem do instrumento, posição da sonda, temperatura ambiente, uso de medicações e outras condições que alteram o fluxo medido). 


\subsection{Frações do sinal Doppler}

A TAB. 5.2 apresenta os valores de fluxo medidos de nove incisivos centrais, com e sem a manta de látex. A mesma tabela também apresenta os valores da variação percentual de fluxo entre as duas condições, bem como o valor médio da variação percentual de fluxo, $F C(\%) / F S(\%)=64,9 \%$, onde $\mathrm{FC}(\%) / \mathrm{FS}(\%)$ é interpretada como a parcela de fluxo proveniente da região peridental e pulpar, pois de acordo com Soo-ampon et al. (2003) e Hartmann et al. (1996) a parcela de fluxo da região gengival foi supostamente suprimida (ou diminuída).

No Capitulo 3 foi citado que a quantidade $F$, medida num pequeno volume ao qual o FLD é sensível, é proporcional à velocidade eficaz das hemácias nesta região, que podem ter, cada uma, direção, sentido e velocidade diferente. Mas quando duas regiōes distantes são irradiadas, os campos elétricos das radiações retro-espalhadas de cada região são combinados no detector, e é possivel provar que (a prova é simples, mas foge do escopo deste trabalho):

$$
F=F p o+F g e+F p e
$$

onde $F$ é o fluxo total medido em um dente intacto, Fpo é a parcela de fluxo da polpa, Fge é a parcela da região gengival e Fpe é a parcela da região peridental. Normalizando a Eq. (5.1), ou seja, expressando-a em termos das frações de cada parcela, tais que somadas resultam $100 \%$, a expressão fica:

$$
100 \%=F p o(\%)+F g e(\%)+F p e(\%)
$$

A Eq. (5.2) expressa as fraçōes medidas em cada dente. É possível provar que a Eq. (5.2) também é válida para os valores médios de cada fração, resultando o valor médio do grupo e prosseguir estimando intervalos de confiança das frações. Mas a análise que segue é restrita, supondo distribuições normais e que as médias das frações. obtidas dos respectivos grupos amostrais, são as melhores estimativas pontuais das médias populacionais. Nestas condições desejamos conhecer as parcelas Fpo, Fpe e Fge. Mas somente tem-se 
$\mathrm{FC}(\%) / \mathrm{FS}(\%)$ que corresponde à soma de Fpo e Fpe (significando que $35,1 \%$ de $F$ origina da gengiva). Uma alternativa para encontrar as frações Fpo e Fpe seria suprimir uma das duas. Mas enquanto, como uma alternativa, medições em um mesmo dente nos dois estados (vitalizado e desvitalizado) pode ser realizado mais facilmente em animais (e. g., Vongsavan e Mattews, 1993), em humanos não.

TABELA 5.2: Valores de fluxo de nove incisivos centrais sem a manta de látex, e com a manta de látex e valores das variações percentuais de fluxo.

\begin{tabular}{lccc}
\hline Dente/Fluxo & $\begin{array}{c}\text { Fluxo (UA) } \\
\text { Sem blindagem } \\
\text { FS(UA) }\end{array}$ & $\begin{array}{c}\text { Fluxo (UA) } \\
\text { Com blindagem } \\
\text { FC(UA) }\end{array}$ & FC/FS $\times 100$ \\
\hline D1 & 20,4 & 5,6 & 27,5 \\
D2 & 9,3 & 9,7 & 103,9 \\
D3 & 18,3 & 8,6 & 46,9 \\
D4 & 19,3 & 13,2 & 68,3 \\
D5 & 11,3 & 9,4 & 83,4 \\
D6 & 9,9 & 7,6 & 76,9 \\
D7 & 18,8 & 8,2 & 43,5 \\
D8 & 16,6 & 7,5 & 45,3 \\
D9 & 10,5 & 9,3 & 88,5 \\
& & & \\
Média & 15,2 & $\mathbf{8 , 8}$ & 64,9 \\
Desvio Padrão & 4,4 & 2,1 & 25,4 \\
\hline
\end{tabular}

Durante o periodo de execução deste trabalho, usando as mesmas condições experimentais, Eduardo (2004) estudou a variação percentual de fluxo entre vinte pares de dentes anteriores homólogos, sendo um saudável e outro endodonticamente tratado (quando $F p u=0$ ). Ou seja, $F(\%)$ neste caso significa a variação percentual do fluxo medido de um dente desvitalizado em relação ao seu homólogo saudável, denominada $\mathrm{FD}(\%)$, significando a variação percentual de fluxos entre um dente desvitalizado e seu homólogo saudável do mesmo individuo. Neste estudo a variação percentual média observada entre os pares foi $F D(\%)=39,6 \%$. Neste mesmo estudo foi verificado que a variação percentual 
entre pares de dentes homólogos saudáveis (variação de fluxo entre dentes homólogos saudáveis do mesmo individuo), denominada $\mathrm{FV}(\%)$, foi próxima a $100 \%$ : $F V(\%)=102 \%$. Aproximando $\mathrm{FV}(\%)$ a $100 \%$, e tomando os valores médios de $F D(\%)$ e $F V(\%)$ então

$$
F D(\%)=39,6 \%=F g e(\%)+F p e(\%)
$$

pois $F p o=0$.

Usando a TAB. 5.2 tem-se

$$
F C(\%)=64.9 \%=F p o(\%)+F p e(\%)
$$

admitindo que Fge = 0, ou seja, que a parcela de fluxo gengival foi suprimida (ou por compressão de vasos ou por bloqueio óptico). Somando membro a membro (5.3) e (5.4), tem-se

$$
104,5 \%=(F p o+F p e+F g e)+F p e=100 \%+F p e
$$

Logo, de (5.5) tem-se que Fpe $(\%)=4,5 \%$. Com este resultado, de (5.3) tem-se que $\mathrm{Fge}(\%)=35,1 \%$ e de $(5.4)$ tem-se que $\mathrm{Fpo}(\%)=60,4 \%$. Ou seja, aproximadamente $60 \%$ da quantidade $\mathrm{F}$ medida é originada da polpa, aproximadamente $5 \%$ do periodonto e $35 \%$ da gengiva. Note-se que este resultado somente é válido para o arranjo usado. Caso mude um dos seguintes (principais) fatores: o molde de fixação, o sensor, o fluxômetro, a faixa Doppler, o tipo de dente e a distância do sensor até a margem gengival, as frações acima poderão alterar largamente. Note-se ainda que os valores de $F D(\%)$ e $F V(\%)$ foram derivados de dentes anteriores, mas não necessariamente incisivos centrais. Assim, e considerando as outras restrições acima impostas análises mais detalhadas das frações são de interesse como temas de trabalhos futuros.

Dentro das restrições da análise acima, o resultado mais importante para o presente trabalho é que apenas uma pequena parcela de $F$ medido origina da região peridental, mais especificamente do ligamento peridental e de tecidos subjacentes. A importância deste resultado é explorada no capítulo seguinte. 


\subsection{Alterações de fluxo durante o nivelamento}

Os valores de $F(U A)$ dos doze pacientes estudados, nos instantes 0 min; 20 min: 48h; $72 h$ e 1 mês, são apresentados no APÊNDICE $A$, na TAB. A5.1. Alterações dos valores de fluxo expressos na TAB. A5.1 são analisadas na seqüência, tomando como referência os valores da sessão inicial. antes da aplicação da força. Os mesmos valores são também analisados quando transformados nos seguintes indicadores de alterações de fluxo: variações percentuais de fluxo, $F(\%)$, e diferenças entre fluxos, $F$ (dif), definidos no Capítulo 4. Os valores de $F(\%)$ e $F$ (dif) são apresentados nas TAB. (A5.2) e (A5.3) respetivamente, no APÊNDICE $A$.

Os valores de fluxo de cada paciente constantes na TAB. A5.1 são apresentados na FIG. 5.1, marcados por símbolos, onde os intervalos entre as sessōes são linearmente interpolados. Mas note-se que não há como sustentar a validade dos traçados resultantes das interpolações nos intervalos entre as sessões: servem apenas como guias para melhor acompanhamento visual de cada traçado entre as sessões. As FIG. (5.3) e (5.5) mostram os valores de $F(\%)$ e de $F$ (dif) respectivamente, de cada sessão e de cada paciente.

No gráfico da FIG. 5.2 são apresentados os valores mínimos, os percentis $5,25,50$ (igual à mediana), 75 e 90 , os valores máximos e os valores médios em UA de cada sessão durante o nivelamento. Os parâmetros são apresentados como Box-Plots, com marcas, do topo acima de cada caixa para baixo, representando o valor máximo, os percentis $95,75,50,25$ e 5, e o valor mínimo. O valor médio é representado por um quadrado. A FIG. 5.2 facilita avaliar 0 comportamento desses principais descritores estatísticos do grupo investigado ao longo das sessões, onde podem ser observados pronunciados decréscimos nos valores médios e medianos dos fluxos imediatamente após a aplicação das forças. permanecendo baixos até $72 \mathrm{~h}$ após, e retornando a valores próximos aos iniciais 30 dias depois. As FIG. (5.4) e (5.6) mostram Box-Plots de $F(\%)$ e $F$ (dif) respectivamente.

Nota-se nas FIG. (5.1), (5.3) e (5.5) fluxos diminuidos (F(UA), F(\%) e F(dif)) na sessão $20 \mathrm{~min}$, em 11 dos 12 dentes avaliados, quando comparados aos valores iniciais $(0 \mathrm{~min}$ ) indicando ter sido uma resposta predominante no grupo 
investigado. Esta resposta além de predominante foi intensa: os valores médio e mediano de $F(U A)$ do grupo decresceram respectivamente $63,1 \%$ e $57 \% 20$ minutos após aplicadas as forças, quando relativos aos fluxos médios e medianos (respectivamente) antes das forças (FIG. 5.2).

Os valores de $F(\%)$ mediano e médio na sessão 20 min são menores que os respectivos valores no instante inicial, reduzidos a $64,4 \%$ e $61,9 \%$ do fluxo inicial, 100\%. respectivamente (FIG. 5.4).

Na sessão subseqüente, $48 \mathrm{~h}$, os fluxos de 11 indivíduos (de $F(U A), F(\%)$ e $F($ dif)) foram menores que os respectivos valores iniciais, também indicando ser uma resposta predominante.

$\mathrm{Na}$ sessão $72 \mathrm{~h}$, os fluxos de 11 individuos são menores que seus respectivos valores iniciais, indicando um comportamento coletivo. Os valores dos fluxos médios e medianos de $F(U A)$ nas sessões $48 \mathrm{~h}$ e $72 \mathrm{~h}$ são pronunciadamente menores que os valores médios e medianos respectivamente iniciais (FIG. 5.2).

Os valores dos fluxos medianos e médios de $F(\%)$ nas sessões $48 \mathrm{~h}$ e $72 \mathrm{~h}$ são menores que os respectivos iniciais e menores que os respectivos valores na sessão $20 \mathrm{~min}$. Ou seja, os fluxos decresceram na sessão $72 \mathrm{~h}$ mesmo quando comparados com a sessão 48h (FIG. 5.4).

Na sessão 1 mês, os fluxos de 11 individuos são pronunciadamente maiores que os respectivos valores na sessão imediatamente anterior, e são próximos aos respectivos valores iniciais. Os valores médio e mediano de $F(U A)$ nesta sessão são próximos aos respectivos valores iniciais (FIG. 5.2). O valor mediano de $F(\%)$ nesta sessão ainda é baixo $(82,5 \%)$ e o valor médio é próximo ao valor inicial $(98,7 \%)$, quando comparados aos respectivos valores iniciais, 100\%, (FIG. 5.4). Nesta sessão, as diferenças de fluxo de 7 individuos são negativas e as de 5 indivíduos são positivas, mas com valores absolutos próximos a zero, FIG. 5.5. Os valores mediano e médio absolutos de $F$ (dif) nesta sessão são pronunciadamente menores que os respectivos valores nas sessões anteriores (exceto os da sessão $0 \mathrm{~min}$ ), FIG. 5.6.

Assim, no grupo estudado ocorreu diminuição de fluxo em 11 dos 12 dentes avaliados, nas sessões $20 \mathrm{~min}$, 48h e $72 \mathrm{~h}$, quando comparados aos valores iniciais ( $0 \mathrm{~min}$ ) indicando ser uma resposta predominante. Os valores dos indicadores de fluxo mediano e médio $F(U A), F(\%)$ e $F($ dif) nestas sessões são 
progressivamente menores, de $0 \mathrm{~min}$ até $72 \mathrm{~h}$, e tendem a retornar aos valores iniciais um mês após aplicadas as forças.

O comportamento do grupo analisado foi o acima exposto. As análises seguintes objetivaram avaliar se os dados obtidos contêm evidências estatisticas suficientes para inferir o comportamento das populações das quais as amostras foram colhidas.

Usando o teste Ryan-Joiner, não foram encontradas evidências suficientes para rejeitar a hipótese nula de que as distribuições de valores de $F(U A), F(\%)$ e $F($ dif) nas sessões estudadas sejam normais. Mas valores elevados de correlação (sugerindo normalidade), segundo o teste usado, somente ocorrem em algumas sessões de todos os indicadores. Analisando as FIG. (5.2); (5.4) e; (5.6), verificase em algumas sessōes elevadas diferenças nos valores medianos e médios, mas ainda são aproximadamente simétricas em torno das respectivas medianas. Desta forma testes Wilcoxon para uma e duas amostras dependentes, conforme o caso, foram empregados nas inferências seguintes.

O teste Wilcoxon para duas amostras dependentes, usado nas análises de F(UA) entre as sessões $0 \mathrm{~min}, 20 \mathrm{~min}, 48 \mathrm{~h}, 72 \mathrm{~h}$ e 1 mês, quando comparadas entre si (e. g., entre $48 \mathrm{~h}$ e $20 \mathrm{~min}$ ), foi implementado partindo das diferenças (pareadas) entre fluxos entre as sessōes interrogadas. Assim, resulta o mesmo algoritmo que o teste de Wilcoxon para uma amostra quando usado nas análises de $F($ dif), pois são as diferenças entre fluxos entre as mesmas sessões. Portanto os dois testes (duas amostras dependentes para $F(U A)$ e uma amostra para $F($ dif)) produzem os mesmos resultados estatísticos quando as sessōes são comparadas. Assim na seqüência apenas uma das duas possiveis análises (de $F(U A)$ ou de $F($ dif)) foram efetuadas quando duas sessōes foram comparadas. 


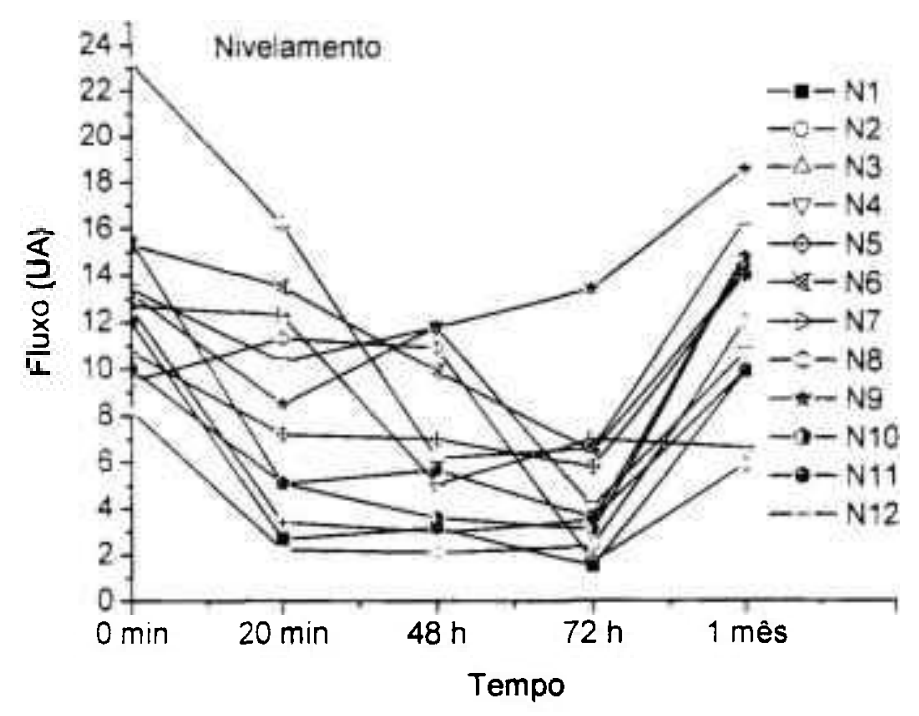

FIGURA 5.1: Valores de fluxo de 12 indivíduos medidos nos instantes 0 min, 20 min, 48h, 72h e 1 mês após aplicadas as forças, em unidades arbitrárias (UA). $O$ eixo das abscissas está em escala não linear para evidenciar as sessões.

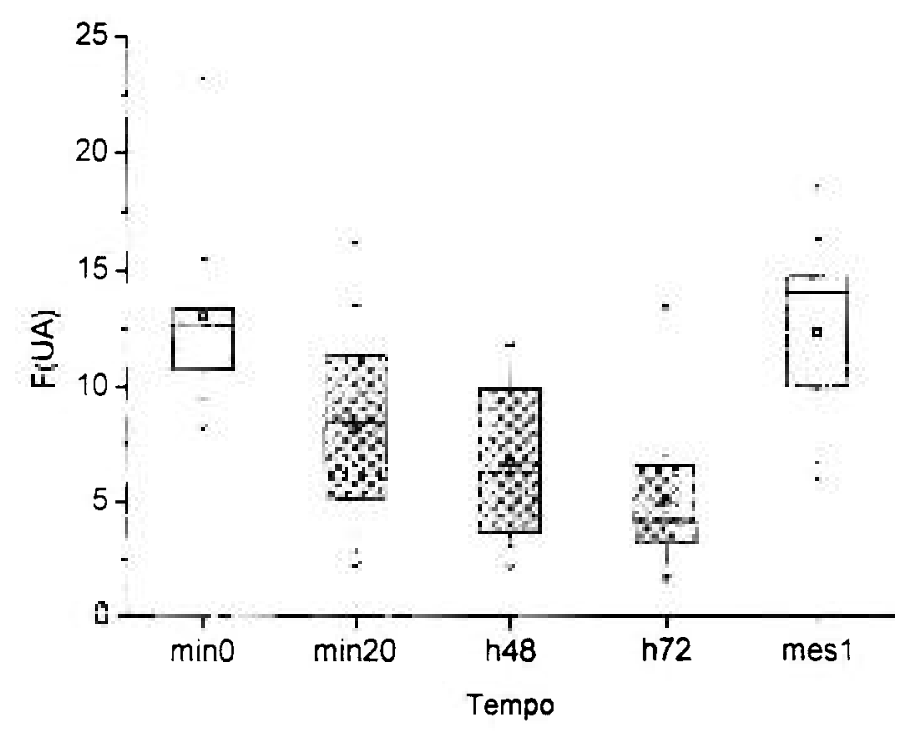

FIGURA 5.2: Valores minimos e máximos, dos percentis $5,25.50,75,95$ e valor médio dos fluxos de 12 individuos, medidos nos instantes $0 \mathrm{~min}, 20 \mathrm{~min}, 48 \mathrm{~h}, 72 \mathrm{~h}$ e 1 mês após a aplicação das forças, em unidades arbitrárias (UA). O eixo das abscissas está em escala não linear para evidenciar as sessões. 


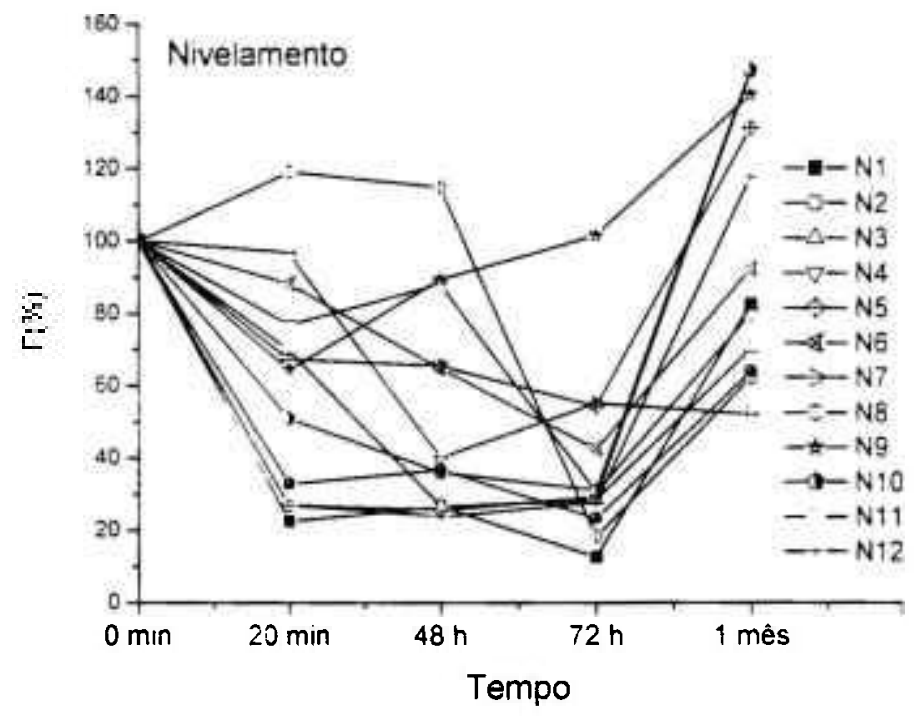

FIGURA 5.3: Valores de $F(\%)$ de 12 individuos nos instantes $0 \mathrm{~min}, 20 \mathrm{~min}, 48 \mathrm{~h}$, $72 \mathrm{~h}$ e 1 mês após a aplicação das forças em porcentagens (\%). O eixo das abscissas está em escala não linear para evidenciar as sessões.

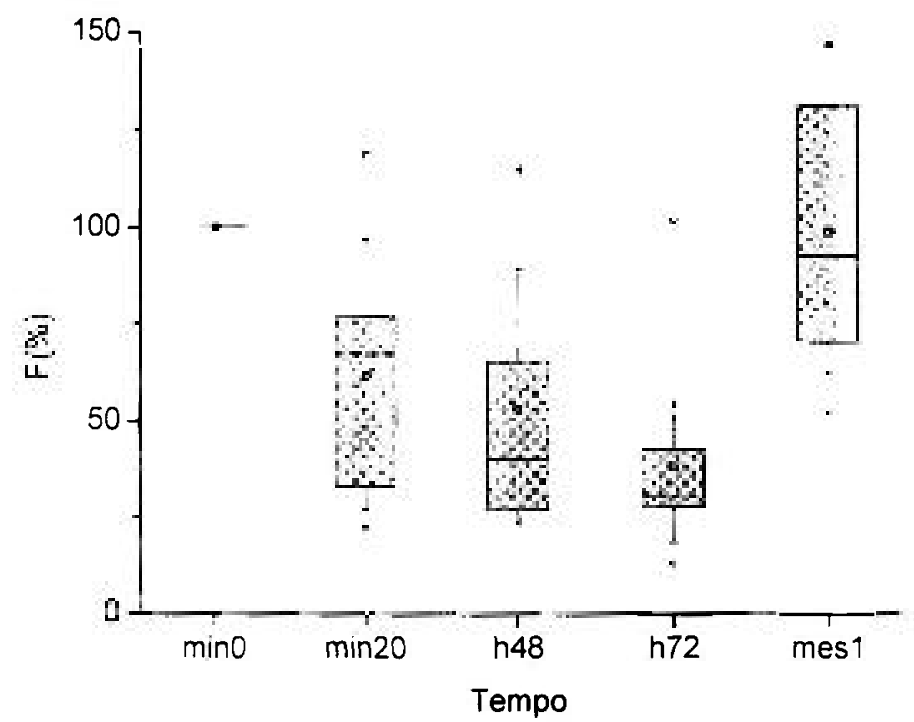

FIGURA 5.4: Valores mínimos e máximos, dos percentis 5, 25, 50, 75, 95 e valor médio de $F(\%)$ de 12 individuos. medidos nos instantes 0 mın. $20 \mathrm{~min}$, 48h, 72h e 1 mês após a aplicação das forças, em porcentagens (\%). O eixo das abscissas está em escala não linear para evidenciar as sessões. 


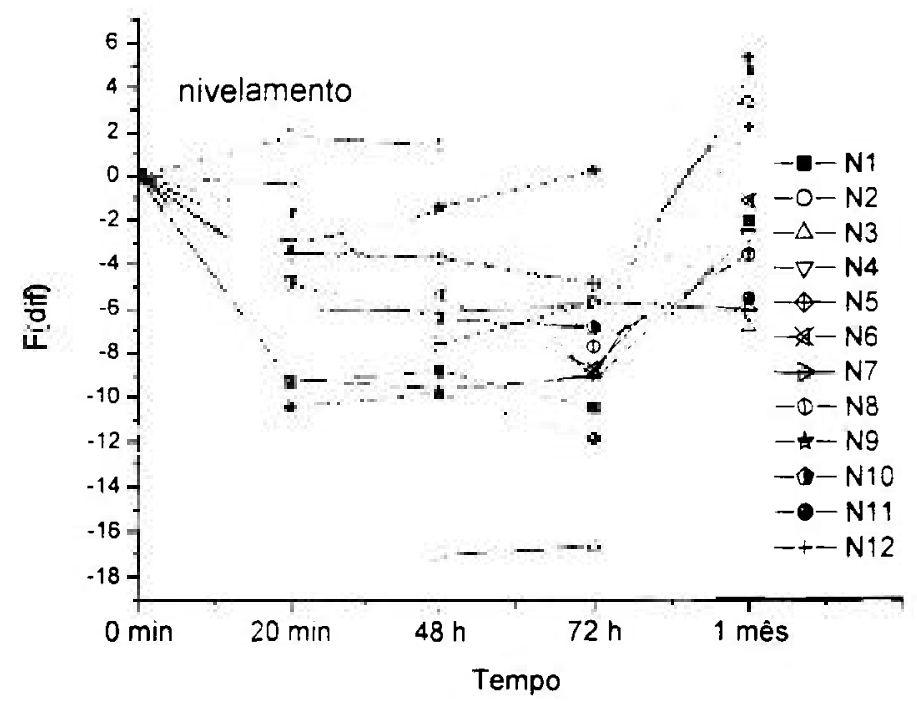

FIGURA 5.5: Valores de $F$ (dif) de 12 individuos nos instantes $0 \mathrm{~min}, 20 \mathrm{~min}, 48 \mathrm{~h}$, $72 \mathrm{~h}$ e 1 mês após a aplicação das forças em unidades arbitrárias (UA). O eixo das abscissas está em escala não linear para evidenciar as sessões.

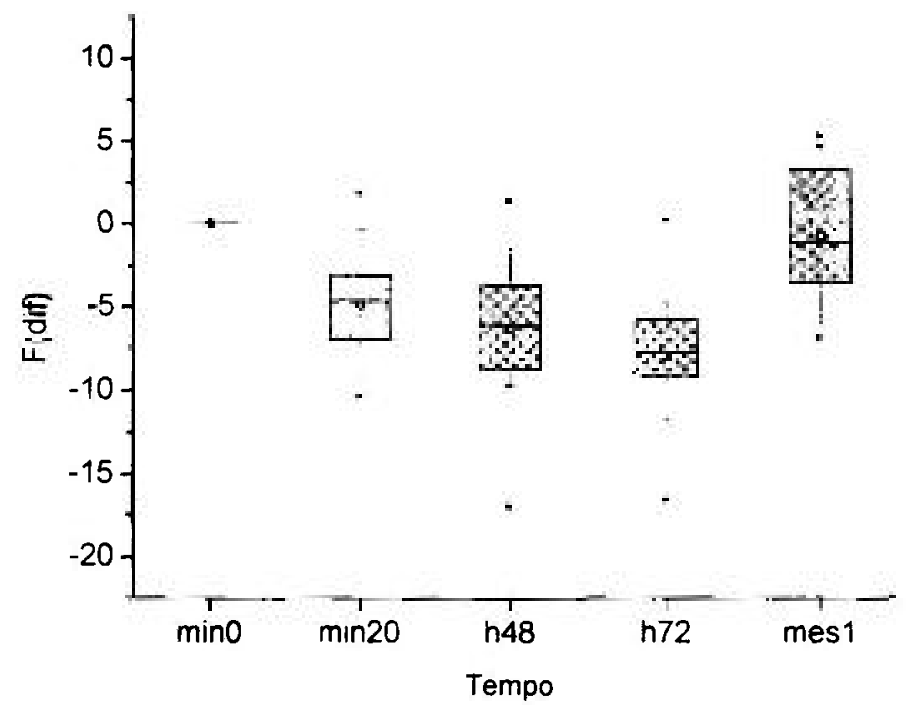

FIGURA 5.6: Valores mínimos e máximos, dos percentis $5,25,50,75,95$ e valor médio de $F$ (dif) de 12 individuos, medidos nos instantes $0 \mathrm{~min}, 20 \mathrm{~min}$. 48h, $72 \mathrm{~h} \mathrm{e}$ 1 mês após a aplicação das forças. em unidades arbitrárias (UA). O eixo das abscissas está em escala não linear para evidenciar as sessões. 
Testando os valores da TAB. A5.3 (APÊNDICE A5) com o teste de Wilcoxon encontra-se evidências estatísticas suficientes $(p<0,05)$ para inferir que as medianas de $F$ (dif) sejam menores que zero nas sessões $20 \mathrm{~min}$, 48h e $72 \mathrm{~h}$ ( $p$ $\leq 0,002$ ). Mas não há diferença significativa entre as medianas de $F$ (dif) das sessões 0 min e 1 mês $(p=0,61)$. O intervalo de confiança da mediana de $F$ (dif) em 1 mês está entre $-4,05$ UA a 2,2 UA para $95 \%$ de significância, obtido usando o método de Wilcoxon, incluindo, portanto, o valor zero. Note-se que estes resultados (valores de probabilidade) são aplicáveis a $F(U A)$.

Assim nos dados constantes na TAB. A5.1 e A5.3 há evidências estatísticas suficientes para inferir que os valores medianos populacionais dos indicadores $F(U A)$ e $F($ dif) nos instantes $20 \mathrm{~min}, 48 \mathrm{~h}$ e $72 \mathrm{~h}$ sejam menores que os respectivos valores medianos no instante inicial, para o valor de probabilidade $p<0,05$. Mas não há evidências suficientes para inferir que os valores medianos de $F(U A)$ e de $F$ (dif) no instante 1 mês sejam diferentes ou iguais aos respectivos valores no instante inicial, para $p<0,05$. Usando o método de Wilcoxon, o intervalo de confiança (IC) estimado do fluxo mediano na sessão 1 mês é (9,9 UA a 14,7 UA), para $95 \%$ de significância, enquanto a o IC do fluxo mediano estimada no instante inicial é $(10,75$ UA a 15,30 UA). A intersecção entre os ICs é elevada, mas a faixa também. Assim não há evidências suficientes para admitir que valores medianos de $F(U A)$ e $F($ dif) após um mês sejam próximos ou iguais aos valores iniciais.

O teste de Wilcoxon para duas amostras dependentes resulta diminuição significativa ( $p=0,013$ ) de $F(U A)$ entre as sessões 0 mim e 20 min e entre 20 min e $72 \mathrm{~h}$. Não há diferença entre as sessōes $20 \mathrm{~min}$ e $48 \mathrm{~h}$ e entre $48 \mathrm{~h}$ e $72 \mathrm{~h}$, para $p<0,05$, mas há aumento significativo entre as sessões $72 h$ e 1 mês $(p=0,002)$. Este resultado também sustenta as afirmações que seguem: $F$ (dif) decresce significativamente entre as sessões $0 \mathrm{~min}$ e $20 \mathrm{~min}$, entre $20 \mathrm{~min}$ e $72 \mathrm{~h}$, e aumenta entre as sessões $72 \mathrm{~h}$ e 1 mês

Portanto, há evidências estatísticas suficientes para inferir que a mediana de $F(U A)$ (e de $F($ dif)) decresce imediatamente após a aplicação da força, continua decrescendo na sessão $72 \mathrm{~h}$ em relação à sessão $20 \mathrm{~min}$, e aumenta entre as sessões $72 \mathrm{~h}$ e 1 mês.

Usando o teste de Wilcoxon para uma amostra, há evidências estatísticas suficientes $(p<0,05)$ para admitir que $F(\%)$ seja menor que $100 \%$ nos instantes 20 
$\min , 48 \mathrm{~h}$ e $72 \mathrm{~h}(\mathrm{p} \leq 0,003)$. O mesmo teste sugere ausência de evidências de que $F(\%)$ mediana seja diferente de $100 \%$ na sessão 1 mês $(p=1)$. $O$ intervalo de confiança da mediana de $F(\%)$ na sessão 1 mês é $(72.1 \%, 119.6 \%)$ para significância de $95 \%$, enquanto a mediana no momento inicial é 100\%. Assim, é razoável admitir que o valor mediano de $F(\%) 1$ mês após a aplicação da força seja próximo ou igual ao valor de $F(\%)$ inicial, antes do tratamento.

O teste Wilcoxon para duas amostras foi usado para verificar se a mediana de $F(\%)$ na sessão 1 mês é superior à mediana na sessão $72 h$, resultando evidências suficientes $(p=0,002)$. O mesmo teste foi usado para verificar se a queda da mediana de $F(\%)$ entre as sessões $20 \mathrm{~min}$ e $72 \mathrm{~h}$ foi significativa, resultando $p=0,013$, mas não há evidências que os $F(\%)$ variou entre as sessões 20 min e $48 h$, e entre $48 h$ e $72 h$, para $p<0,05$.

Portanto, há evidências suficientes para inferir que a mediana de $F(\%)$ decresce imediatamente após a aplicação da força, continua diminuindo entre as sessões 20 min e $72 \mathrm{~h}$, e retorna a valores próximos ou igual ao valor inicial 1 mês após.

\subsection{Alterações de fluxo durante a retração}

Os valores de fluxo de 13 incisivos centrais de 13 individuos monitorados durante seis sessões na fase de retração: antes da ativação das forças ( 0 min); 20 minutos (20 min); 48 horas (48h); 72 horas ( $72 h$ ); 1 mês (1 mês) e; 45 dias (45 dias) após a ativação do aparelho ortodôntico são apresentados no APÊNDICE A5, na TAB A5.4.

Um registro na sessão $20 \mathrm{~min}$ foi descartado, por apresentar elevadas variaçōes em todos os três registros realizados nesta sessão, provaveimente decorrente de instabilidades da sonda. As sessões realizadas 45 dias após a ativação das forças foram introduzidas somente depois de ser verificado, nos primeiros registros obtidos nesta fase, que o fluxo ainda permanecia baixo 30 dias após a ativação, lembrando que durante as duas fases estudadas, subgrupos iniciaram seus tratamentos em momentos diferentes. Assim oito registros foram obtidos durante sessões 45 dias após a ativação das forças, mas são informações aditivas aos objetivos e métodos planejados na realização deste trabalho. 
Analogamente ao procedimento descrito na subseção 5.3 deste capítulo, dos valores de fluxo, $F(U A)$, constantes na TAB. A5.4, foram derivados os valores das variaçōes percentuais de fluxo, $F(\%)$, apresentados na TAB. $A 5.5$, e os valores das diferenças entre fluxos, $F($ dif), apresentados na TAB. A5.6. Os valores de $F(U A), F(\%)$ e $F($ dif) de cada sessão e de cada voluntário são apresentados nos gráficos das FIG. (5.7), (5.9) e (5.11) respectivamente. Os valores mínimos, máximos, médios e os percentis $5,25,50,75$ e 95 dos valores de $F(U A), F(\%)$ e $F$ (dif) são apresentados nos gráficos das FIG. (5.8), (5.10) e (5.12) respectivamente.

Na sessão 0 min, o valor mínimo de $F(U A)$ registrado foi de 3,5 UA e o máximo de 21,5 UA, evidenciando a elevada variação de fluxos entre indivíduos. Os valores de $F(\%)$ e $F($ dif) são, por definição, $100 \%$ e 0 UA respectivamente. $O$ valor mediano, médio e desvio-padrão de $F(U A)$ calculados são 9,5 UA, 9,9 UA e 5,3 UA respectivamente, sugerindo que a distribuição é aproximadamente simétrica.

Na sessão $20 \mathrm{~min}$, os registros de dez incisivos apresentaram valores de F(UA) diminuídos e dois aumentados (um registro foi descartado), quando relativos aos respectivos momentos iniciais. Como uma conseqüência apenas dois valores de $F(\%)$ e de $F($ dif) indicam acréscimo de fluxo. Há, portanto, predominância de diminuição de fluxo. O valor médio de fluxo, igual a 6,9 UA, é pronunciadamente menor que o inicial, assim como $F(\%)=68,7$ e $F($ dif $)=-2,8$ UA.

Na sessão 48h, 10/12 dos valores de $F(U A)$ (conseqüentemente de $F(\%)$ e de $F($ dif)) apresentaram diminuição em relação à sessão inicial, 2/12 apresentaram elevação, e um permaneceu inalterado. Novamente, há predominância de fluxos diminuídos. As diminuições do fluxo médio (6,5 UA), da variação percentual de fluxo $(65,7 \%)$ e da diferença média entre fluxos (-3,4 UA) são pronunciadas.

$\mathrm{Na}$ sessão $72 \mathrm{~h}$ apenas um registro apresentou elevação de fluxo em relação ao momento inicial, enquanto os demais apresentaram diminuição pronunciada de fluxo, com valor médio igual a 5,4 UA, $F(\%)$ média igual a 58,8\% e $F(d i f)$ média igual a $-4,5$ UA.

Na sessão 1 mês onze registros ainda apresentaram fluxos diminuidos em relação ao momento inicial, enquanto dois apresentaram discreta elevação de 
fluxo. O valor médio foi de 6 UA, portanto, ainda abaixo do valor médio inicial. $F(\%)$ média foi igual a $63,2 \%$ e $F($ dif) média igual a -3,9 UA.

$\mathrm{Na}$ sessão 45 dias, $5 / 8$ dos registros apresentaram fluxos diminuidos e 3/8 apresentaram discreta elevação de fluxo, resultando valor médio de 6,2 UA, portanto ainda abaixo do valor inicial. Mas a variação percentual de fluxo média foi $90 \%$ e a diferença média entre fluxos igual a $-1,8 \cup A$.

A verificação das alterações das medianas dos indicadores de alterações de fluxo entre as sessões $20 \mathrm{~min}, 48 \mathrm{~h}, 72 \mathrm{~h}$ e 1 mês relativas à sessão inicial $(0$ min) foi efetuada usando os seguintes testes não-paramétricos: Wilcoxon para duas amostras dependentes quando $F(U A)$ foi analisado e Wilcoxon para uma amostra quando $F(\%)$ e $F($ dif) foram analisados, sempre testando a hipótese alternativa de que as medianas nos momentos testados são menores que os respectivos valores na sessão inicial. Os mesmos testes foram usados para verificar a hipótese nula de que as medianas de $F(U A), F(\%)$ e $F$ (dif) na sessão inicial são iguais às respectivas medianas na sessão 45 dias. Pelas razões expostas na subseção anterior, os resultados estatísticos de $F(U A)$ e $F$ (dif) foram os mesmos.

Analisando os valores de probabilidade obtidos, apresentados na TAB. 5.3, há evidências estatísticas suficientes $(p<0,05)$ para rejeitar as hipóteses nulas acima nas sessões $20 \mathrm{~min}, 48 \mathrm{~h}, 72 \mathrm{~h}$ e 1 mês. Assim os decréscimos de fluxo observados nas sessões $20 \mathrm{~min}, 48 \mathrm{~h}, 72 \mathrm{~h}$ e 1 mês relativos à sessão inicial são significativos. Mas não foram encontradas evidências suficientes para rejeitar a hipótese de que os valores medianos de $F(U A), F(\%)$ e de $F($ dif) na sessão 45 dias sejam iguais aos respectivos valores na sessão inicial (0 min). Usando o método de Wilcoxon, para $95 \%$ de significância, os intervalos de confiança dos três indicadores na sessão 45 dias são, respectivamente: (4,05 UA a 8,50 UA), $(59,5 \%$ a $122,6 \%)$ e $(-4,55$ UA a 0.75 UA), enquanto os respectivos valores iniciais são 9,5 UA (estimado usando o método de Wilcoxon); $100 \%$ e; 0 UA. Assim, embora os intervalos de confiança de $F(\%)$ e $F($ dif) incluam os respectivos valores iniciais, considerando a acurácia estimada das medições, não há evidências suficientes para inferir que o fluxo mediano (populacional) 45 após aplicadas as forças seja próximo ou igual ao valor inicial. 


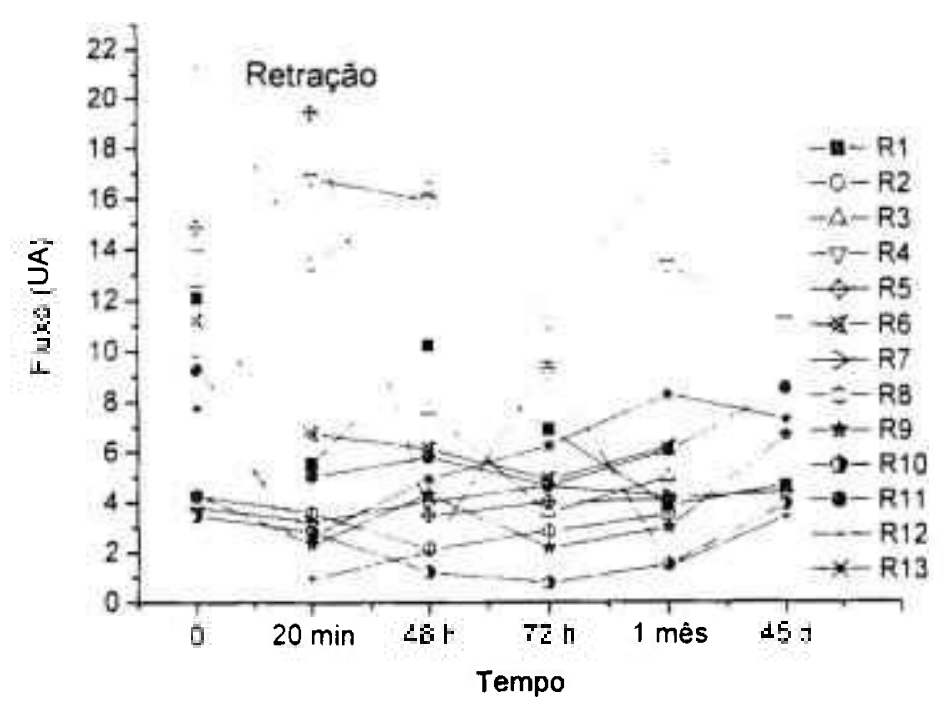

FIGURA 5.7: Valores de fluxo de 13 individuos medidos nos instantes 0 min, 20 min, 48h, 72h, 1 mês e 45 após aplicadas as forças, em unidades arbitrárias (UA). O eixo das abscissas está em escala não linear para evidenciar as sessões.

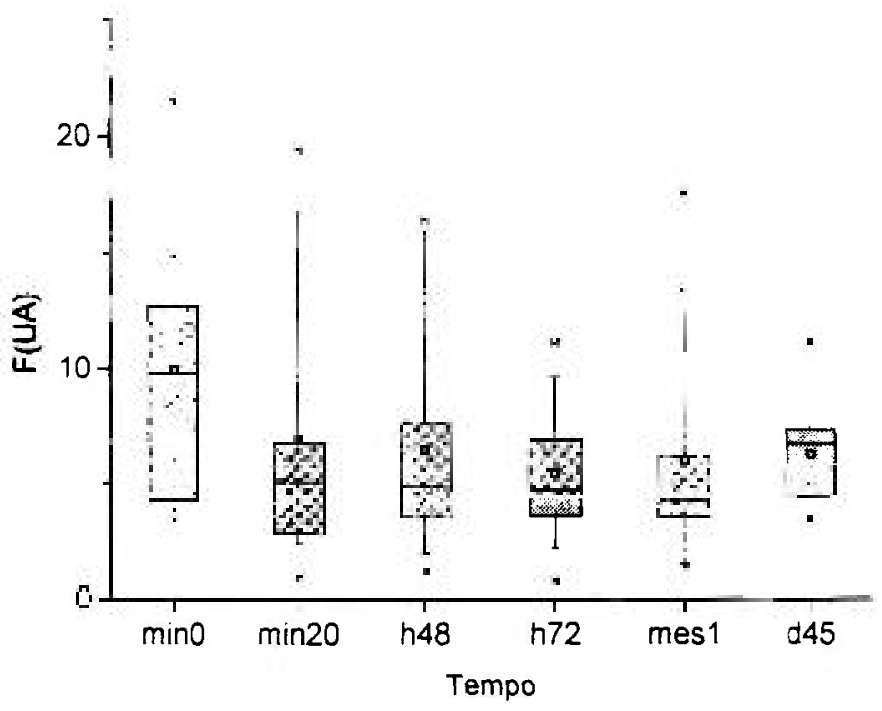

FIGURA 5.8: Valores minimos e máximos, dos percentis $5,25,50,75,95$ e valor médio de $F(U A)$ de 13 individuos, medidos nos instantes $0 \mathrm{~min} .20 \mathrm{~min}, 48 \mathrm{~h}, 72 \mathrm{~h}$, 1 mês e 45 dias após a aplicação das forças, em unidades arbitrárias (UA). O eixo das abscissas está em escala não linear para evidenciar as sessões. 


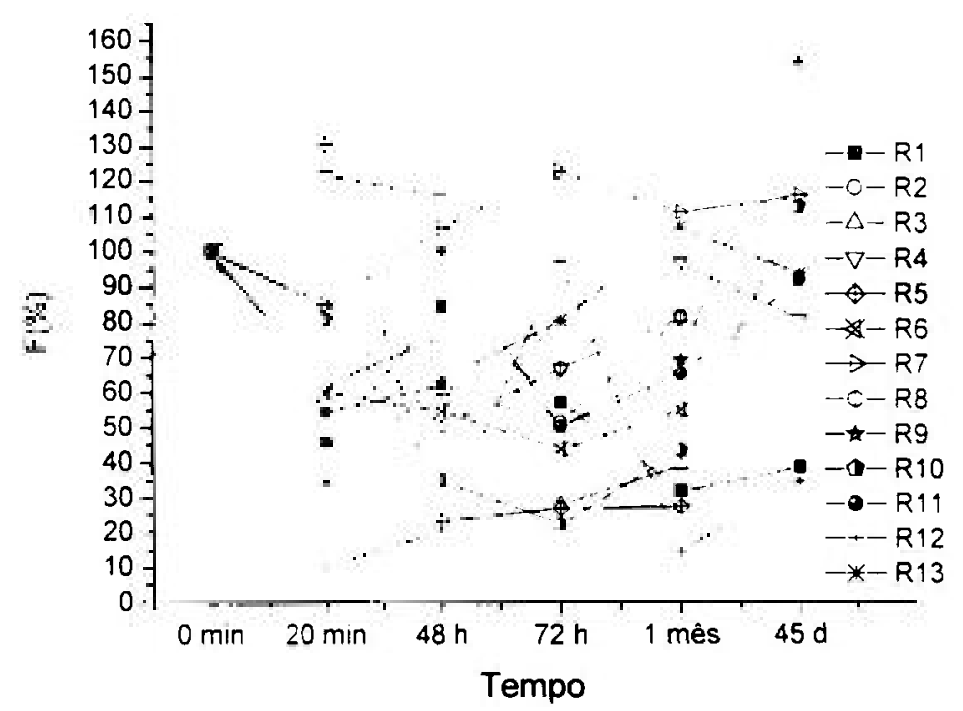

FIGURA 5.9: Valores de $F(\%)$ de 13 indivíduos medidos nos instantes 0 min, 20 min, 48h, 72h, 1 mês e 45 dias após aplicadas as forças, em porcentagem (\%). 0 eixo das abscissas está em escala não linear para evidenciar as sessões.

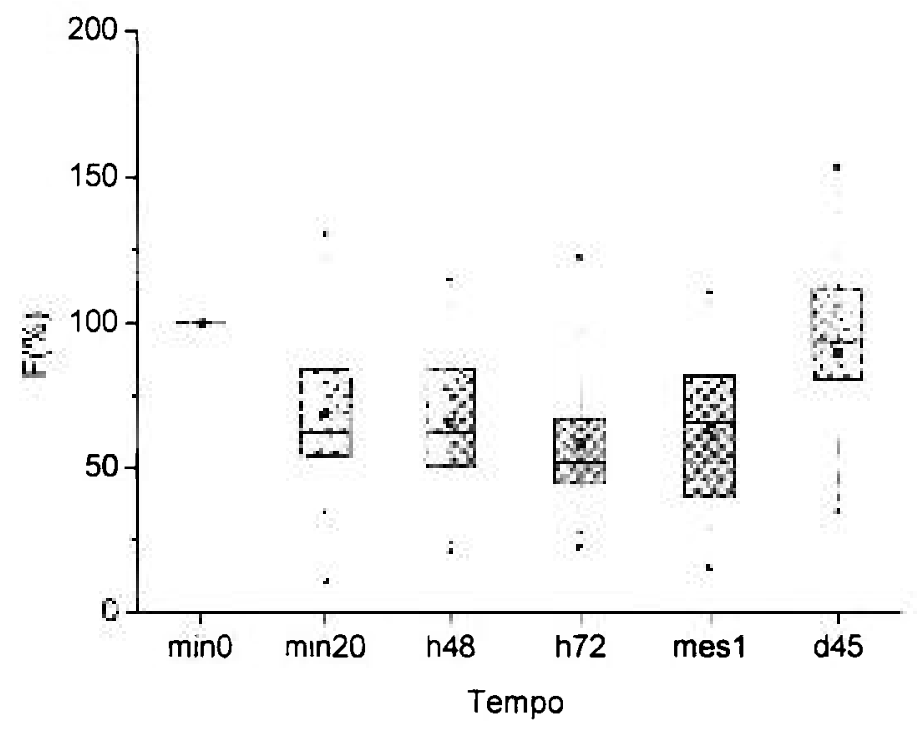

FIGURA 5.10: Valores mínimos e máximos, dos percentis 5, 25. 50, 75. 95 e valor médio de $F(\%)$ de 13 individuos. medidos nos instantes $0 \mathrm{~min} .20 \mathrm{~min} .48 \mathrm{~h}, 72 \mathrm{~h}, 1$ mês e 45 dias após a aplicação das forças, em porcentagem (\%). O eixo das abscissas está em escala não linear para evidenciar as sessões. 


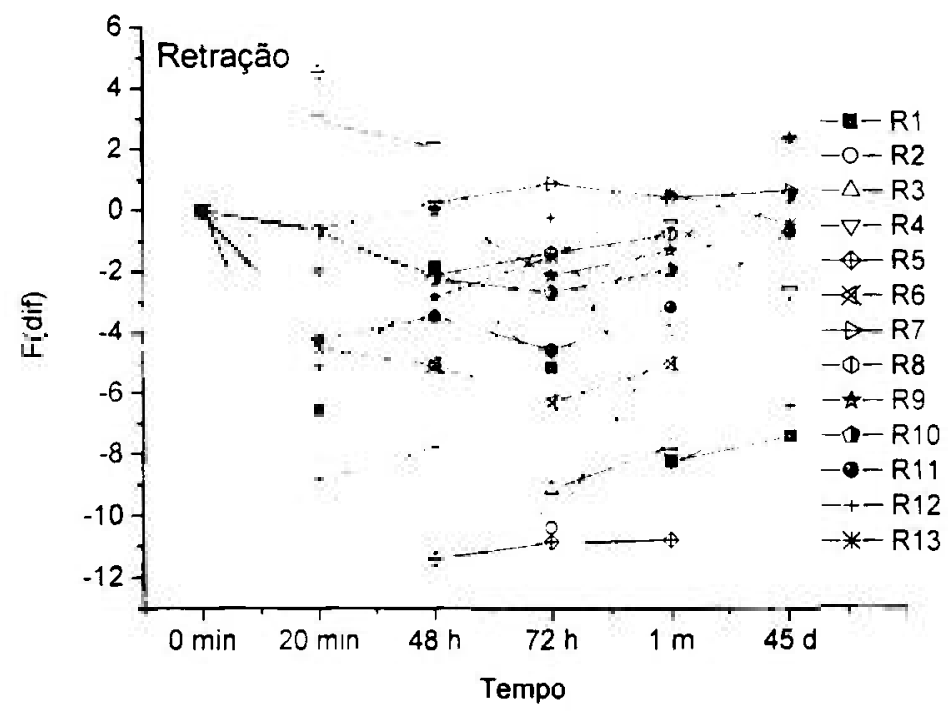

FIGURA 5.11: Valores de $F(d i f)$ de 13 indivíduos medidos nos instantes 0 min, 20 min, 48h, 72h, 1 mês e 45 dias após aplicadas as forças, em unidades arbitrárias (UA). O eixo das abscissas está em escala não linear para evidenciar as sessões.

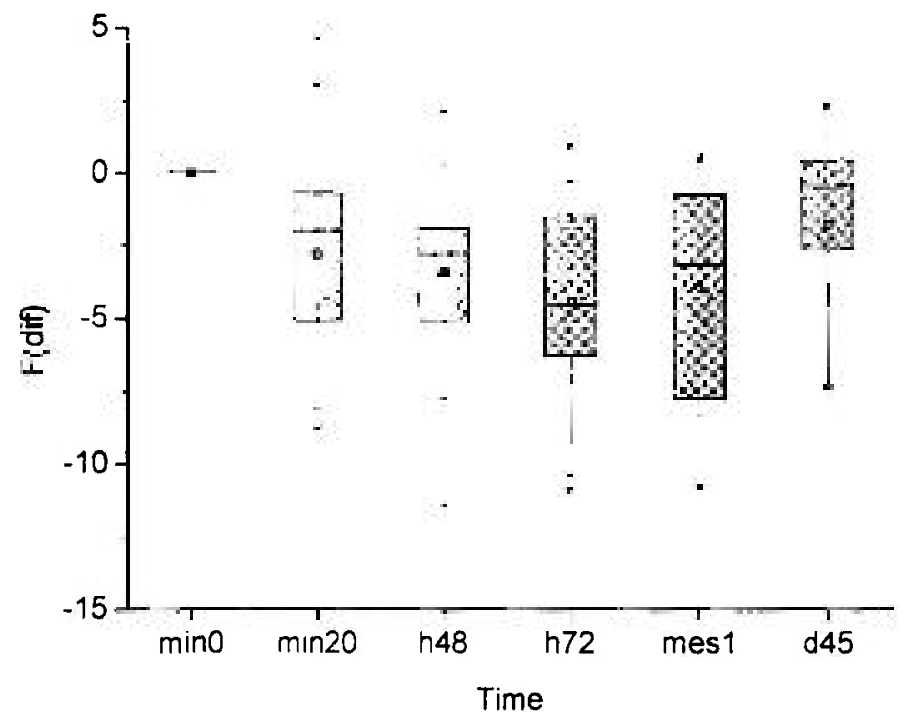

FIGURA 5.12: Valores mínimos e máximos, dos percentis $5,25,50.75 .95$ e valor médio de $F$ (dif) de 13 indivíduos. medidos nos instantes $0 \mathrm{~min}, 20 \mathrm{~min}$. 48h. $72 \mathrm{~h}$, 1 mês e 45 dias após a aplicação das forças, em unidades arbitrárias (UA). O eixo das abscissas está em escala não linear para evidenciar as sessões. 
Usando o teste Wilcoxon para amostras pareadas, não foram encontradas evidências suficientes $(p<0,05)$ para sustentar a hipótese de que há alterações de $F(U A)$ e $F$ (dif) mediano entre as seguintes sessões: 20 min e 48h; 20 min e $72 \mathrm{~h}$; $48 \mathrm{~h}$ e $72 \mathrm{~h}$ e; $72 \mathrm{~h}$ e 1 mês. Para este propósito, uma vez que as comparações foram pareadas, a seqüência de registros R3 foi excluída, e o critério de exclusão foi a ausência de dois registros nesta seqüência ( 20 min e 45 dias). Também não foram encontradas alterações significativas entre as sessões 20 min e 45 dias; $48 \mathrm{~h}$ e 45 dias; $72 \mathrm{~h}$ e 45 dias e 1 mês e 45 dias. Para este propósito, uma vez que as comparações foram pareadas, as seqüências de registros $R 2, R 3, R 5, R 6$ e R8 foram excluídas, e o critério de exclusão foi a ausência de registros na sessão 45 dias nestas seqüências.

TABELA 5.3: Valores de probabilidade (p) quando foram testadas as hipóteses nulas: i) medianas na sessão inicial $(0 \mathrm{~min})$ são maiores ou iguais às respectivas medianas de $F(U A), F(\%)$ e $F($ dif) nas sessões 20 min, 48h, 72h, 1 mês e; ii) medianas na sessão inicial ( 0 min) são iguais às respectivas medianas de $F(U A)$, $F(\%)$ e $F($ dif) na sessão 45 dias.

\begin{tabular}{lccccccc}
\hline & 0 min & 20 min & $48 \mathrm{~h}$ & $72 \mathrm{~h}$ & 1 mês & 45 dias \\
\hline$F($ UA $)$ - Valor de probabilidade $(p)$ & $\times$ & 0,023 & 0,004 & 0,001 & 0,002 & 0.234 \\
$F(\%)$ - Valor de probabilidade $(p)$ & $\times$ & 0,01 & 0,003 & 0,002 & 0,003 & 0.529 \\
$F($ dif $)$ - Valor de probabilidade $(p)$ & $\times$ & 0,023 & 0,004 & 0,001 & 0,002 & 0.234 \\
\hline
\end{tabular}

Portanto, analisando os indicadores de fluxo, $F(U A)$ e $F($ dif), somente foram encontradas as seguintes evidências: decréscimo significativo de fluxo mediano nas sessões $20 \mathrm{~min}, 72 \mathrm{~h}$ e 1 mês quando comparadas à sessão inicial. Mas não há evidências suficientes para admitir que o fluxo mediano (populacional) tende a aumentar após $72 \mathrm{~h}$ e não há evidências que retorna a valores próximos ao inicial aos 45 dias.

Não foram encontradas diferenças significativas de $F(\%)$ entre as sessões 20 min e 48h; 20 min e $72 h ; 48 h$ e $72 h ; 72 h$ e 1 mês e; 1 mês e 45 dias, usando o teste Wilcoxon para amostras pareadas, para $p>0,05$. 
Portanto, somente há evidências estatísticas suficientes para admitir diminuição de fluxo após a aplicação das forças ortodônticas, permanecendo abaixo do valor inicial até 1 mês, mas não há evidências que tendam a retornar ao valor inicial aos 45 dias. 


\section{Discussões}

Os resultados apresentados na seção anterior indicam redução do fluxo pulpar imediatamente após a aplicação das forças ortodônticas investigadas. Estudos anteriores também mostraram que o fluxo diminui imediatamente após a aplicação de forças ortodônticas (ver TAB. 3.1). Uma explicação possivel a este fato é a compressão dos vasos que irrigam a polpa, localizados na região apical do dente (McDonald e Pitt Ford, 1994). Nos momentos posteriores investigados a redução de fluxo pulpar observada não é concordante com o resultado obtido por McDonald e Pitt Ford (1994) (após 48h e 72h) e Vandevska-Radunovic et al. (1994) (após 72 horas), embora seja concordante com outro resultado anterior (ver TAB. 3.1). Mas não é trivial explicar estes resultados, pois ainda não há consenso na literatura acerca dos fenômenos que ocorrem na polpa, decorrentes da movimentação dentária. Mas há conjecturas sobre um possível processo inflamatório pulpar, induzido pela inflamação periodontal decorrente da força ortodôntica.

Neste capitulo são discutidas duas possibilidades que explicam a redução de fluxo pulpar 48 horas e 72 horas após a aplicação de forças, em adição à conjectura já conhecida de que há um processo inflamatório na polpa seguido de compressão dos vasos sangüíneos decorrente da elevação da pressão intersticial pulpar, já mencionada no Capítulo 3. As duas possibilidades aqui formuladas são: i) há somente compressão dos vasos sangüineos que adentram e saem do forâmen apical e anexos e; ii) há edema na polpa e estrangulamento dos vasos sangüineos e linfáticos que saem do forâmen apical. Neste capitulo estas três possibilidades são discutidas, tomando como base o atual conhecimento sobre os fenômenos que ocorrem durante o deslocamento dental. Antes, porém, na seção anterior foi mostrado que uma fração do fluxo medido com o FLD provém de outras regiões, além da polpa.

Alterações no fluxo pulpar dependem de vários fatores, além das forças mecânicas investigadas. Assim muitos fatores devem ser considerados na interpretação dos resultados apresentados no capitulo anterior. Muitos fatores são 
conhecidos, apontados nos Capitulos 3 e 4, e foram controlados (e. g., posição do paciente). Mas outros, embora conhecidos, nem sempre podem ser controlados (e. g., estado emocional do paciente). Outros, ainda que relevantes, eventualmente ainda são desconhecidos. Mas além dos fatores que alteram o fluxo pulpar, devemos também considerar os fatores relevantes que alteram o fluxo gengival e da região do LPD, pois uma fração do fluxo $F$ medido contém contribuições dessas regiōes. Assim surge a seguinte questão: alterações de fluxo na gengiva ou ligamento periodontal (LPD) poderiam resultar erros na interpretação dos resultados obtidos? Neste capítulo também são discutidas possiveis alterações de fluxo na gengiva e LPD durante a movimentação dentária, usando o conhecimento literário disponivel em áreas correlatas.

\subsection{Significado dos indicadores de alterações de fluxo}

$\mathrm{Na}$ variação percentual de fluxo, definida no Capitulo 4 , cada individuo é seu próprio controle. Um outro indicador de alteração do fluxo pulpar usado foi a diferença entre fluxos, também definida no Capítulo 4, tomando como referência o fluxo de cada individuo no momento inicial, antes da aplicação das forças. As vantagens e limitações esperadas destas técnicas (de indicação de variações de fluxo) são discutidas na seqüência, considerando as frações que compõem o sinal de fluxo medido em um dente intacto, e a estabilidade de todo arranjo fluxométrico usado, por não serem abordadas na literatura, e cujos significados são fundamentais na análise e compreensão dos resultados apresentados no capitulo anterior.

\subsubsection{Frações de fluxo pulpar, gengival e periodontal}

As origens do sinal detectado em um dente intacto via FLD foram brevemente apontadas no Capitulo 3. Há, neste momento, consenso na literatura que há contaminação do fluxo pulpar (F) medido com o FLD. Também há, neste momento, consenso na literatura que a blindagem óptica da gengiva diminui a contaminação. Esta subseção foca a questão das frações de fluxo que compõem - sinal de fluxo medido num dente intacto (F), usando a FLD e introduz os 
subsidios necessários à discussão sobre as conseqüências da blindagem óptica da gengiva, explorada nas Subseções 6.2 e 6.3 .

Hartmann et al. (1996) mostraram que a quantidade $F$ medida é aproximadamente $70 \%$ menor quando uma manta de isolamento opaca é aplicada à gengiva (aqui também denominada blindagem óptica). Tomando estes resultados poderíamos concluir que, quando uma blindagem ótica não é usada, aproximadamente $70 \%$ de $F$ origina da gengiva, e que $30 \%$ de $F$ origina da polpa e região do LPD. Mas a questāo seguinte seria: quando a blindagem óptica não é usada (que é o caso do presente trabalho), qual seria a fração, do fluxo medido, oriunda da polpa?

Soo-ampon et al. (2003) concluem algo mais restritivo: que apenas $43 \%$ de F origina da polpa, mesmo quando a blindagem óptica da gengiva é efetuada. Assim poderiamos concluir que sem a manta de isolamento, dos $30 \%$ oriundos da polpa e LPD, apenas $43 \%$ vem da polpa. Ou seja, concluiriamos que sem a manta apenas $13 \%$ de $F$ vem da polpa.

Antes de avaliar a amplitude das afirmações e conclusões acima, devemos considerar que as frações de fluxo que contaminam $F$ dependem dos seguintes fatores já conhecidos na literatura (e abordados no Capítulo 3): da banda Doppler, do comprimento de onda da radiação, da posição da sonda no dente, da forma da sonda, e do suporte de fixação. Em adição a estes fatores largamente conhecidos, no capitulo anterior foi sugerido que também depende da forma de análise da quantidade F. Ou seja, enquanto a literatura analisa quase exclusivamente o parâmetro $F$, aqui analisamos também os parâmetros $F(\%)$ ou $F(U A)$.

Assim deve estar claro que Hartmann et al. (1996), Soo-ampon et al. (2003) e seguidores da técnica de blindagem estudaram ou usaram uma técnica particular, e a alteração de um único parâmetro pode alterar todos os resultados (e. g., forma da sonda). Mas este fato não está claro na literatura atual. Como conseqüência, tem ocorrido uma tendência do uso das condições preconizadas por Hartman et al. (1996) e por Soo-ampon et al. (2003), generalizando os resultados. Na seqüência tais considerações são efetuadas.

Em ambos os trabalhos (Hartmann et al., 1996; Soo-ampon et al., 2003), suportes rígidos, de poliuretano e acrílico respectivamente, foram usados. Em ambos os trabalhos, a banda Doppler foi fixada em $15 \mathrm{KHz}$, usando modelos 
iguais de fluxômetros (MBF3D. Moor Instruments, Axminster, UK), operando em $780 \mathrm{~nm}, \mathrm{e}$ ambas as sondas usadas eram semelhantes. Em ambos os trabalhos mantas de isolamento de látex, ambas na cor preta, foram usadas como blindagens ópticas. As mantas foram aplicadas a dentes anteriores antes das fixações dos suportes rígidos. Em ambos os trabalhos há a sugestão de que a manta absorve a radiação, impedindo que atinja a gengiva e outras regiōes. Mas Soo-ampon et al. (2003) admitem que uma parcela da redução do fluxo medido quando a manta é aplicada é conseqüência da compressão de vasos sangüíneos na gengiva. Antes, Sano et al. (2002) já haviam sugerido que parte da diminuição do fluxo decorrente da blindagem é originada pela compressão de vasos na gengiva. A compressão de vasos sangüíneos na gengiva é importante e é discutida na próxima subseção.

Os resultados apresentados no capitulo anterior mostram que quando uma manta de isolamento foi aplicada, ocorreu redução de aproximadamente $35 \%$ do fluxo medido. Redução menor, portanto, que a redução observada por Hartmann et al. (1996) e Soo-ampon et al. (2003) (de aproximadamente 70\%). As explicações possíveis a este fato são exploradas na seqüência.

No experimento aqui relatado, doravante denominado experimento Ipen, a banda Doppler foi fixada em $3 \mathrm{KHz}$, o suporte de fixação usado foi de silicone e o parâmetro investigado foi variação percentual de fluxo, $F(\%)$, enquanto Hartmann et al. (1996) e Soo-ampon et al. (2003) avaliaram o fluxo F em UA, a banda Doppler usada foi de $15 \mathrm{kHz}$, e os suportes das sondas foram de poliuretano e acrílico, respectivamente. Estas foram as diferenças mais relevantes encontradas entre o experimento Ipen e os relatados por Hartmann et al. (1996) e por Sooampon et al. (2003), dentre os fatores conhecidamente relevantes, acima apontados.

No Capitulo 3 foi mencionado que a banda Doppler determina a faixa de velocidades mensuráveis, e que a limitação da banda Doppler é uma técnica sugerida na literatura para minimizar a contaminação do sinal de fluxo pulpar, pois é conhecido que arteríolas na gengiva são mais largas, resultando. geralmente, velocidades de fluxo superiores às da polpa. Esta técnica tem sido seguida, sustentada principalmente por estudos realizados por Odor et al. (1996a, 1996b), quando várias bandas Doppler e desenhos de sonda diferentes foram testadas, visando discriminar dentes vitalizados e desvitalizados. O objetivo foi encontrar a 
maior diferença entre os valores de fluxo, $F$, de dentes vitalizados $e$ desvitalizados, variando os parâmetros acima, dentre outros. Para este propósito, a melhor banda encontrada foi a de $3,1 \mathrm{KHz}$ e o melhor espaçamento entre fibras foi de $0,5 \mathrm{~mm}$ (Odor et al. 1996b). Bandas superiores $(14,9 \mathrm{KHz}$ e $22,1 \mathrm{kHz}$ ) resultaram valores de fluxo entre dentes saudáveis e desvitalizados mais próximos, e conseqüentemente com menor capacidade de discriminação (provavelmente decorrente de frações maiores de contaminação). Odor et al. (1996b) usaram uma sonda contendo duas fibras com espaçamentos de 0,5 mm, similar às usadas por Hartmann et al. (1996) e Soo-ampon et al. (2003) e similar à usada no experimento Ipen. Portanto, as evidências mostram que o uso da banda Doppler de $3 \mathrm{kHz}$ resulta menor contaminação, que é o caso do experimento Ipen.

Também é interessante destacar outros resultados parciais e não explorados por Odor et al. (1996b). Neste estudo, usando um arranjo semelhante ao usado no experimento Ipen, os fluxos médios $(n=20)$ de dentes vitalizados e desvitalizados foram respectivamente 11,8 UA e 4,4 UA, significando que a fração de fluxo não pulpar é aproximadamente de $37,3 \%$. Próxima, portanto, da encontrada no experimento Ipen.

Outro fator que difere o experimento Ipen dos realizados por Hartmann et al. (1996) e Soo-ampon et al. (2003), é o método usado parar calcular as frações.

Consideremos FS e FC os fluxos medidos em um dente sem e com a manta de isolamento, respectivamente.

A fração gengival média de fluxo, FC/FS, apresentada no capítulo anterior foi calculada tomando os valores das variações percentuais de fluxo após e antes a aplicação da manta de isolamento de cada dente (FC/FS) e efetuando a média aritmética desses valores:

$$
\overline{F C / F S}=\frac{\sum_{1}^{n} F C n / F S n}{n} \cdot 100
$$

onde n é o número de dentes. 
Nos demais estudos citados nesta subseção (Hartmann et al., 1996 e Sooampon et al., 2003) as frações foram derivadas de valores médios de fluxo, de dentes e indivíduos diferentes:

$$
\overline{F C / F S}=\frac{\sum_{1}^{m} F C m}{\sum_{i}^{m} F S n} \cdot \frac{n}{m} \cdot 100
$$

onde $\mathrm{m}$ e $\mathrm{n}$ são os números de dentes com e sem a manta respectivamente.

Portanto, os dois métodos usados foram diferentes, e as quantidades resultantes geralmente são diferentes. Resta saber qual método é mais adequado.

Consideremos a fração obtida pela razão entre fluxos de um mesmo dente, medidas com e sem a manta de isolamento. Esta fração expressa a porcentagem de $F$ medido, oriunda supostamente da gengiva, para o dente investigado. Outro dente resulta eventualmente outra fração. A fração média de um grupo é a média das frações de cada dente do grupo. Logo o método usado no capitulo anterior é adequado.

No entanto, nem sempre (6.1) resulta o mesmo valor que (6.2). Como um exemplo, na TAB. 5.2, a fração média encontrada com a Eq. (6.1) é 64,9\%, enquanto a fração entre os fluxos médios sem e com manta seria $\overline{F C / F S}=8,8 / 15,2=57,9 \%$. Neste último caso o resultado errôneo seria a fração média oriunda da gengiva de $42,1 \%$, e não $35,1 \%$.

A fração de fluxo periodontal foi aqui derivada usando a variação percentual de fluxos entre dentes homólogos, sendo um vitalizado e outro desvitalizado. Este método apresenta duas desvantagens. A primeira é que os dentes desvitalizados usados no trabalho de Eduardo (2004) apresentavam seus canais já endodonticamente tratados. Como uma conseqüência, é possível que tanto as propriedades ópticas do esmalte e dentina como certamente as da câmara pulpar estavam alteradas. Outra desvantagem é o fato de esta fração ser derivada de outro grupo de amostras, embora ainda derivada de pares de dentes. Mais adequado seria medir tais frações de dentes com polpas sem fluxo, mas não necrosadas, e não tratadas. Mas em humanos, esta seria uma tarefa dificil de ser 
realizada. Uma alternativa seria realizar medições de fluxo em dentes com polpas necrosadas antes de serem endodonticamente tratadas. Esta é uma sugestão para trabalhos futuros.

Retornando ao inicio desta subseção, quando foram apontados os principais fatores que alteram as frações do sinal de fluxo (banda Doppler, comprimento de onda da radiação, posição da sonda no dente, forma da sonda, e do suporte de fixação), uma vez que os trabalhos acima abordados não diferem do arranjo usado no experimento Ipen quanto ao comprimento de onda e os outros fatores já foram tratados, resta explorar o material usado na confecção do suporte da sonda.

Nos trabalhos de Hartmann et al. (1996) e Soo-ampon et al (2003), os materiais dos suportes usados foram poliuretano e acrílico, respectivamente. Não foi possivel saber sobre as características ópticas do poliuretano usado por Hartmann et al. (1996). Mas o suporte acrílico usado era semitransparente, enquanto 0 material usado no experimento Ipen era altamente opaco (espalhador).

Quando um dente é irradiado, uma fração significativa da radiação espalhada pelo esmalte e dentina atinge o suporte, e é retroespalhada pelo suporte (quando este é espalhador), retornando ao dente. A fração que é transmitida ao suporte é atenuada fortemente, devido ao elevado coeficiente de espalhamento. Assim, a radiação fica confinada no dente (discussão na seqüência). Mas quando o suporte é menos espalhador (semitransparente), a radiação espalhada pelo esmalte e dentina pode atingir outras regiões. Mas questiona-se aqui se seria possivel um caminho óptico entre a sonda, ajustada ao esmalte numa região (A) na FIG. 6.1 até a gengiva, numa região (B) na FIG. 6.1 e retorno, quando o material é o silicone usado no experimento Ipen.

Uma vez que o ângulo que a sonda é sensivel é estreito (aproximadamente 10 graus), a radiação teria o seguinte caminho óptico: uma fração da radiação espalhada pelo esmalte e dentina atinge o suporte e é espalhada, retornando ao dente, mas uma fração é transmitida pelo suporte da sonda. Uma pequena fração desta radiação espalhada no suporte da sonda atinge a gengiva. Uma fração desta radiação espalhada na gengiva faz o caminho inverso, atinge o esmalte, é transmitida pelo esmalte (pouco espalhador) e dentina (altamente espalhador), e somente a fração retro-espalhada nesta região seria coletada pela sonda (devido 
ao pequeno ângulo de aceitação da sonda). Assim a radiação teria que propagar entre 3 a $4 \mathrm{~mm}$ pelo suporte. Mas considerando as propriedades ópticas do suporte de silicone este caminho é pouco provável, pois ensaios realizados (não divulgados) mostraram que a radiação decai a niveis abaixo da sensibilidade do FLD quando apenas dois milímetros de silicone é usado entre a sonda e um meio contendo partículas móveis. No caso do acrílico, ainda assim seria um caminho pouco provável, pois a radiação retroespalhada pelo esmalte seria transmitida pelo acrilico e atingiria outras regiōes remotas, e não a gengiva. É mais provável que o silicone e o acrílico sejam eficazes na blindagem óptica entre a sonda e a gengiva. Neste caso, a diminuição do fluxo observado quando a blindagem foi aplicada pode ter sido decorrente da compressão dos vasos sangüineos na gengiva livre, na região interna situada em contato com o esmalte. Esta possibilidade é apontada por Soo-ampon et al. (2003) e por Sano et al. (2002). A verificação desta possibilidade é outra sugestão de trabalhos futuros. Mas, as desvantagens da compressão da gengiva, tanto pelo suporte de fixação da sonda quanto pela manta de isolamento é explicada na subseção 6.3.2, pois há evidências de que a compressão da gengiva resulta diminuição de fluxo. Aqui, é suficiente antecipar que, caso a compressão seja pequena, o fluxo gengival inicialmente diminuido retorna ao nivel basal em poucos minutos. Neste caso, medições efetuadas enquanto o fluxo retorna ao basal são instáveis. Assim, embora haja uma tendência atual de usar a blindagem óptica da gengiva, enquanto não for quantificada e controlada esta provável fração (compressão de vasos), é preferivel não usar a blindagem. Uma alternativa para minimizar interferências do fluxo gengival é avaliar a diferença entre fluxos. Mas esta técnica requer o controle de fatores que resultem alteraçōes do fluxo gengival. Este assunto é explorado na subsecção 6.3. 


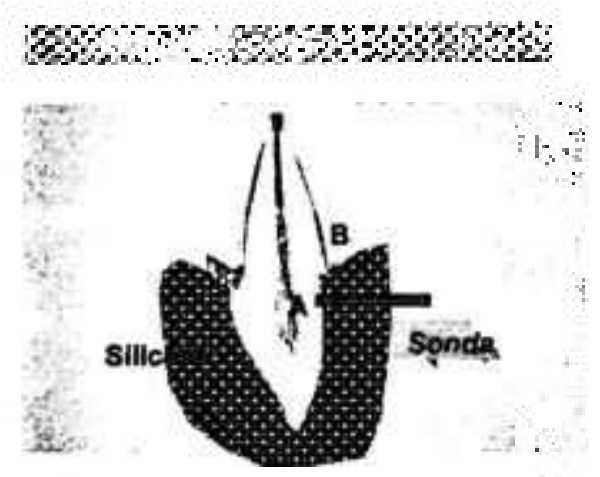

FIGURA 6.1: Desenho do suporte de fixação (S) da sonda mostrando o caminho óptico entre a região onde a sonda irradia o esmalte $(A)$ e a gengiva $(B)$.

\subsubsection{Indicadores de alteraçōes de fluxo}

A fluxometria laser Doppler tem sido usada no estudo de variações do fluxo da polpa dentária, não somente durante curtos periodos como também durante longos intervalos de tempo. Como um exemplo, Mesaros et al. (1997), estudaram variações de fluxo até 76 dias após trauma de incisivos centrais permanentes observando sua revascularização. Mas muitos estudos falharam. Como um exemplo, McDonald e Pitt Ford (1994) falharam ao tentar medir variaçōes de fluxo durante um movimento experimental de retração $96 \mathrm{~h}$ após a aplicação da força. As prováveis razões são, dentre outras, variações individuais de fluxo pulpar e erros no posicionamento da sonda.

O presente estudo objetivou avaliar alteraçōes de fluxo pulpar antes e após a aplicação de forças ortodônticas durante um intervalo de tempo de até um mês (e em alguns casos até 45 dias). Assim, foi necessário minimizar o problema das variações individuais de fluxo e controlar outros fatores que resultariam erros.

Nogueira (2003) explorou $F(\%)$ sugerindo ser menos sensivel que $F(U A)$ a erros de calibragem do instrumento, e a variações individuais de fluxo. Wanderley (2004) mostrou que $F(\%)$ também apresenta vantagens em relação a $F($ UA) mesmo quando $F(\%)$ é derivado entre dentes incisivos não homólogos. Depois, Eduardo (2004), usando modelos matemáticos, demonstrou este fato, e também explorou outro parâmetro $F($ dif), definido-o como a diferença entre fluxos, mostrando ser menos sensivel que $F(U A)$ às contaminações dos fluxos das regiōes peridental e gengival. O modelo desenvolvido por Eduardo (2004) é 
aplicável a dentes homólogos. Adaptando o modelo de Eduardo (2004) ao caso em que os fluxos medidos são originados de um mesmo dente, fica:

$$
F(\%)=\frac{k \times F_{h}}{k \times F_{a}} \times 100=\frac{F_{h}}{F_{n}} \times 100
$$

sendo $\mathrm{Fa} \mathrm{e} \mathrm{Fb}$ os fluxos medidos num mesmo dente, sendo aqui $\mathrm{Fa}$ o fluxo antes da aplicação da força, e Fb após a aplicação da força, $k$ significa um erro de calibragem do instrumento e ou variações individuais de fluxo. Note-se que $k$ é cancelado, e $F(\%)$ é insensivel a erros de calibragem e às variações individuais de fluxo.

Aqui a diferença de fluxo é definida como:

$$
F(\text { dif })=F_{b}-F_{a}
$$

Recorrendo à Eq. (5.1) do fluxo expandido em parcelas, nos mesmos instantes (a e b) tem-se:

$$
F(\text { dif })=\left(F_{b} p o+F_{b} p e+F_{b} g e\right)-\left(F_{a} p o+F_{a} p e+F_{a} g e\right)
$$

Admitindo que $F_{b} g e=F_{a} g e$, ou seja, que os fluxos na região gengival não são alterados entre as sessões (a) e (b) tem-se:

$$
F(\text { dif })=\left(F_{b} p o-F_{a} p o\right)+\left(F_{b} p e-F_{a} p e\right)
$$

Mais adiante será discutida a possibilidade de controlar o experimento para assegurar que $F_{b} g e \cong F_{a} g e$. Mas mais adiante também será mostrado que é esperado que $F_{b} p e \neq P_{a}$ pe durante um movimento dentário. No entanto, mesmo que $F_{\mathrm{o}} p e \neq F_{\mathrm{a}} p e$, o resultado acima sugere que esta parcela é pequena e o erros são, conseqüentemente, pequenos.

Portanto, $F(\%)$ minimiza variações individuais de fluxo e erros de calibragem no instrumento e $F$ (dif) minimiza o fluxo da região gengival que 
contamina $F(U A)$. As conseqüências destes fatos são exploradas na próxima subseção, lembrando que aproximadamente $35 \%$ de $F(U A)$ origina da gengiva.

\subsubsection{Controle e estabilidade dos registros}

Embora a variação percentual de fluxo apresente vantagens quando comparada ao uso de um grupo controle independente, é necessário saber qual é a estabilidade do método usado nas medições durante longos periodos. Mas não há, na literatura, estudos avaliando a estabilidade das medições usando um arranjo igual ao empregado durante a execução deste trabalho.

O Intervalo de confiança da acurácia relativa estimado foi de $-13,6 \%$ a $5,8 \%$ para $94,1 \%$ de significância, definida como o desvio percentual do valor mediano da variação percentual de fluxo, usando, portanto a definição do indicador $F(\%)$.

No entanto, é esperado que a técnica de fixação da sonda, o comprimento de onda do laser do instrumento, o espaçamento das fibras ópticas, a distância da sonda em relação a margem gengival entre outros fatores, influenciem a estabilidade das medições. Assim, qualquer outro arranjo requer a análise da acurácia relativa.

\subsection{Alterações de fluxo periodontal durante a movimentação ortodôntica}

Há uma quantidade limitada de estudos sobre a dinâmica das alterações do fluxo sangüíneo periodontal em humanos, como conseqüência de forças mecânicas. Tal carência decorre provavelmente da dificuldade de acesso não invasivo a tais estruturas. As técnicas quantitativas de estudo de alterações de fluxo anteriormente citadas no Capítulo 3 são inadequadas a este propósito. Contudo, a pletismografia óptica fornece algumas informaçōes acerca das alterações do fluxo sangüineo: a técnica somente é sensivel a alterações do volume sangüineo no tecido interrogado, quando comparado ao volume basal, durante um intervalo de tempo pequeno o suficiente para que possa ser considerado que as propriedades ópticas do tecido não alteraram, exceto as alterações decorrentes do fluxo microvascular. A técnica consiste em iluminar o 
tecido interrogado e medir variações das intensidades da fração retroespalhada e da fração transmitida (transiluminação).

Há evidências em vários estudos sobre o deslocamento dental quando sob carga que duas fases distintas ocorrem: a primeira apresenta baixa resistência mecânica e é rapidamente reversivel (poucos segundos); e uma segunda, apresentando maior resistência mecânica, e é lentamente reversivel (entre $60 \mathrm{~s}$ a 90 s) (apud Packman et al. 1977).

Experimentos usando a pletismografia óptica em humanos sugerem que nas regiōes tensionadas do LPD ocorrem duas fases, Packman et al. (1977). Tensões produzidas por forças horizontais entre $0,9 \mathrm{~N}$ a $1,8 \mathrm{~N}$ resultaram aumento de fluxo, provavelmente decorrente da diminuição da pressão intersticial. Mas acima destas cargas ocorreram alterações bifásicas de fluxo: um aumento inicial de fluxo, seguido por um progressivo decréscimo (com um atraso entre $2 \mathrm{~s}$ a $5 \mathrm{~s}$ ), freqüentemente caindo abaixo do nível basal depois de $5 \mathrm{~s}$ (portanto antes da fase de alta resistência). Pressões produzidas nas mesmas condições resultaram sempre decréscimo de fluxo, proporcionais às forças aplicadas. A técnica não permitiu quantificar as variações de fluxo, mas os resultados indicam que o volume sangüíneo cai nas regiōes comprimidas e aumenta, nas regiões levemente tensionadas, mas cai nas regiōes intensamente tensionadas após alguns segundos. Esta última possibilidade pode ser explicada pelo mecanismo de auto-regulagem da microcirculação: quando a pressão tissular cai, as paredes dos vasos expandem na direção de menor pressão. Mas logo após há contração da musculatura lisa dos vasos e esfincteres pré-capilares, diminuindo o fluxo. Este mecanismo reflexo local, observado em muitos tecidos, parece ser suficientemente rápido para resultar as alterações observadas, Packman et al. (1977).

Retornando ao experimento Ipen, consideramos que a radiação laser espalha por toda região do periodonto. Não há qualquer evidência razoável indicando que o fluxômetro seja mais sensivel a uma região, e. g., a de compressão, ou à outra (de tensão), a depender da localização da sonda. O fato é que há um estudo in vitro sugerindo que a radiação é guiada preferencialmente até a polpa (Odor et al., 1996) e outro, também in vitro, sugerindo que a radiação seja espalha por toda região da polpa e periodonto (Ikawa et al., 1999). Assim, foi admitido que o fluxo de qualquer região (tensão ou compressão) possa estar 
contaminando o sinal Doppler no arranjo usado na realização deste trabalho. Ainda, foi considerado que as forças usadas tinham intensidades variadas, dependendo da posição inicial de cada incisivo em ambas as fases (nivelamento e retração), embora tenha sido propositalmente escolhida a uniformidade nas posições iniciais. Assim, nas regiões de tensão pode ter ocorrido tanto redução quanto acréscimo de fluxo e nas regiões de pressão, provavelmente ocorreu diminuição de fluxo. Assim, tanto acréscimo como decréscimo de fluxo podem ter ocorrido na região periodontal. No entanto, tais alterações significaram, no máximo, aproximadamente $5 \%$ do fluxo medido antes da aplicação da força. Assim, como um exemplo, caso a alteração de fluxo na região periodontal tenha sido de $50 \%$ como conseqüência da força, e que o fluxo na região da gengiva não alterou, significa que $2,5 \%$ da variação percentual de fluxo observada, $F(\%)$, originou do periodonto.

\subsection{Alterações de fluxo gengival durante a movimentação ortodôntica}

Dentre os fatores que podem alterar o fluxo gengival durante a movimentação dentária, além dos fatores conhecidos e controláveis (já citados nos Capitulos 3 e 4), nesta subseção são explorados mais detalhadamente dois fatores: um eventual processo inflamatório gengival e cargas mecânicas na gengiva (pressão).

\subsubsection{Inflamação gengival}

Ainda não há consenso se um eventual processo inflamatório gengival durante um tratamento ortodôntico é conseqüência dos materiais usados (bráquetes, adesivos, fios) ou decorrente da dificuldade de assepsia bucal ocasionada principalmente por aparelhos ortodônticos fixos. Contudo, dentro do complexo polpa, região periodontal e gengiva, a gengiva é o único tecido visualmente acessivel. Neste caso, sinais de um processo inflamatório podem ser facilmente visualizados. Ainda, indicadores objetivos tais como o indice gengival e a sondagem da profundidade da bolsa periodontal auxiliam a detecção de um processo inflamatório, Vandevska-Radunovic (1999). Contudo, não excluindo a possibilidade da ocorrência de um processo inflamatório gengival não notado, na 
seqüência é explorada a influência da inflamação gengival na interpretação dos resultados apresentados no capítulo anterior.

Dos sinais cardinais da inflamação, o rubor e o calor têm sido associados a alterações regionais do fluxo sangüíneo. Mas há evidências discordantes sobre a natureza de tais alterações. Como exemplos, observações em animais revelam que a inflamação gengival resulta laços capilares mais numerosos, restrição nos vasos aferentes e demais vasos alargados com velocidades de fluxo menores. Este conjunto de alterações tem sido denominado vascularidade aumentada. Nestas condições, observações de parte do plexo microvascular de cães, usando a microscopia vital, revelaram estase sangüinea em capilares. Esta ocorrência tem sido interpretada como decréscimo de fluxo, Kerdvongbundit et al. (2002). No entanto, medições do fluxo regional em gengivas inflamadas em cães, usando microesferas radioativas (marcadas), indicaram acréscimo de fluxo, Kerdvongbundit et al. (2002). Em humanos, usando a FLD, foi observado que a gengivite moderada resulta $45 \%$ de aumento de fluxo na gengiva livre, $62 \%$ na papila interdental, $38 \%$ na gengiva inserida e $21 \%$ na mucosa alveolar. Estas variações foram calculadas usando resultados parciais em Kerdvongbundit et al. (2002). Ainda usando a FLD em humanos apresentando gengivite moderada, foram observados acréscimos de fluxo de até $123 \%$ na gengiva livre, $120 \%$ na papila interdental, $50 \%$ na gengiva inserida e $28 \%$ na mucosa alveolar. Estas variações foram calculadas usando resultados parciais em Kerdvongbundit et al. (2003). Assim, embora resultados usando outras técnicas possam ser discordantes, há evidências mostrando que o fluxo medido via FLD durante a gengivite é significativamente maior quando comparado ao fluxo da gengiva sadia.

Retornando ao experimento Ipen, foi mostrado que aproximadamente $35 \%$ de $\mathrm{F}$ origina da gengiva. Mesmo considerando que uma gengivite moderada seria visualmente notada (e nesta condição este dado seria excluído), e ainda considerando que tal condição resultasse $100 \%$ de aumento de fluxo, nesta condição $F$ medido seria, caso as outras frações estivessem inalteradas, $35 \%$ superior. Assim, como um exemplo, considerando os resultados obtidos referentes ao nivelamento (apresentados no capitulo anterior), uma inflamação pulpar desenvolvida depois da aplicação da força iria resultar uma diminuição nas 
alteraçōes observadas nas sessões $48 \mathrm{~h}$ e $72 \mathrm{~h}$ (porque houve decréscimo de fluxo nestas sessões).

\subsubsection{Influência de cargas mecânicas no fluxo gengival}

Existem poucas informações sobre alterações do fluxo gengival como conseqüência de cargas mecânicas. Ainda, os poucos estudos encontrados são restritos aos casos de pressão, e não fornecem informações sobre as magnitudes das pressões investigadas. Contudo, os raros estudos encontrados na literatura sobre este tópico, efetuados em humanos e usando a FLD, são concordantes: há decréscimo de fluxo quando há compressão. Usando dados fornecidos por Baab et al. (1986), o fluxo na gengiva livre caiu aproximadamente $76 \%$ depois de 2 a 3 s quando pressionada. Cessada a pressão, o fluxo aumentou $40 \%$ em relação ao basal (hiperemia), mas retornou ao nivel basal 3 minutos após. Contudo, embora a força usada tenha sido mencionada $(1,5 \mathrm{~N})$, a pressão não. A pressão foi produzida aplicando força à sonda contra a gengiva. Mas a sonda usada não foi especificada. Admitindo que sondas usadas na década de 80 do século passado apresentavam diâmetros entre $2,5 \mathrm{~mm}$ a $5 \mathrm{~mm}$, a pressão exercida seria entre 0,7 $\mathrm{kg} / \mathrm{cm}^{2}\left(7 \mathrm{~N} / \mathrm{cm}^{2}\right)$ a $3 \mathrm{~kg} / \mathrm{cm}^{2}\left(30 \mathrm{~N} / \mathrm{cm}^{2}\right)$. Portanto elevadas quando comparadas às que eventualmente ocorrem durante o processo de medição de fluxo, decorrentes do suporte da sonda. No experimento Ipen, o suporte de silicone eventualmente produziu pressão em algumas regiões da gengiva, pois o molde é ajustado sob leve pressão. Mas a pressão resultante provavelmente foi algumas dezenas de vezes menor que as acima estimadas. Um estudo posterior, mas restrito à gengiva inserida, mostrou redução de fluxo de aproximadamente $85 \%$ quando pressionada (pressão desconhecida), Patiño-Marín et al. (2005). Não foram encontrados estudos na literatura sobre o tópico acima para pressões prolongadas. Mas o tópico seguinte sugere qual seria o comportamento do fluxo gengival nestas condiçōes.

Quando uma força mecânica é aplicada horizontalmente a um dente, produz um deslocamento. Quando dois incisivos centrais se deslocam no sentido de encontro (e. g., arco-mola aplicado entre eles), a gengiva inserida entre tais incisivos é comprimida. Nestas condições, usando a FLD, observou-se em humanos que o fluxo nesta região da gengiva diminuiu após a aplicação da força, 
mas o fluxo retornou ao nivel basal mesmo mantendo a força aplicada. Quando a força aplicada foi de $0,5 \mathrm{~N}$, a queda de fluxo foi de $30 \%$, retornando ao nivel basal 10 minutos após, mesmo mantendo a força aplicada, Yamaguchi et al. (1991).

Durante o experimento Ipen, eventualmente ocorreu compressão e estiramento em algumas regiões da gengiva, por ação dos deslocamentos dos dentes. Dada a carência de informações mais precisas sobre os efeitos da compressão e ausência de informações sobre o estiramento gengival, conjecturase aqui duas respostas de fluxo possíveis: o fluxo alterou e permaneceu alterado, ou alterou e retornou ao nivel basal ou próximo. No primeiro caso, a análise da variação percentual de fluxo e a análise da diferença entre fluxos não cancelam a contaminação, mas é razoável supor que apenas uma fração de $35 \%$ tenha sido alterado. Mas foram observadas alteraçōes médias mais intensas que $35 \%$, sugerindo que o fluxo da polpa também alterou. No segundo caso (o fluxo alterou e retornou ao nivel basal), as alteraçōes provavelmente não foram detectadas, pois todas as medições foram realizadas aproximadamente 20 minutos após a aplicação da força.

Retornando ao problema das frações, discutido na subseção 6.1, Sano et al. (2002) e Soo-ampon et al. (2003) admitem que parte da redução do fluxo medido após a aplicação da manta de isolamento é decorrente da compressão de vasos na gengiva. Mas esta possibilidade e principalmente as conseqüências não são exploradas na literatura. Assim surge a possibilidade de existirem duas parcelas na fração de $F$ proveniente da gengiva: uma parcela referente à blindagem óptica e outra parcela referente à compressão da gengiva, ainda desconhecidas. Recorrendo aos dados apresentados por Hartmann et al. (1996), mas não explorados pelos autores, é possível investigar tais parcelas. Neste experimento, duas blindagens foram testadas: uma manta opaca de isolamento e uma folha de $\mathrm{Sn}$ e $\mathrm{Pb}$. Seria razoável esperar que os decréscimos de fluxo decorrentes das blindagem fossem semelhantes, ou mais pronunciado no caso da folha de $\mathrm{Sn}$ e $\mathrm{Pb}$, pois a manta de látex usada somente atenuou $50 \%$ da radiação laser (ver Soo-ampon et al., 2003), enquanto a folha de $\mathrm{Sn}$ e $\mathrm{Pb}$, provavelmente extraída de blindagens de filmes radiográficos, blinda praticamente toda radiação. No entanto, o decrescido de fluxo medido resultante da aplicação da folha de Sn e $\mathrm{Pb}$ foi menor. Este fato não explorado pelos autores sugere que a parcela óptica é pequena quando comparada à parcela da compressão. Assim é razoável admitir 
que a parcela de compressão é importante. Mas a compressão produzida por mantas de látex não é controlável, provavelmente resultando compressōes variáveis, resultando indesejáveis decréscimos de fluxo variáveis e frações variáveis. Ainda, qualquer acomodação da manta durante as medições resulta variaçōes na fração. Em adição, mecanismos de compensação local de fluxo podem ocorrer quando a gengiva é comprimida, tornando o fluxo instável durante a medição. Assim, é razoável supor que ainda é necessário conhecer as parcelas de compressão e blindagem e eventualmente controla-las, antes de usar a técnica de blindagem recomendada principalmente por Soo-ampon et al. (2003).

\subsection{Alterações do fluxo pulpar durante a movimentação ortodôntica}

Foi apontado no Capítulo 3 que movimentos ortodônticos experimentais resultaram alterações de fluxo tanto imediatamente após a aplicação de forças ortodônticas como nos dias seguintes. Mas enquanto os resultados indicam redução de fluxo imediatamente após a aplicação de forças, as alteraçōes observadas nos dias seguintes são contraditórias (aumento e decréscimo de fluxo, ver TAB. 3.1). Antecipando as discussões seguintes, as prováveis razões são variadas: inadequação das forças experimentais, inadequação das técnicas de medição de fluxo ou na interpretação dos resultados, variabilidade de respostas individuais ao mesmo estímulo, entre outras. Agravando este cenário, a quase totalidade do conhecimento atual acerca deste tópico vem de experimentos que usaram técnicas de medição de fluxo que não permitem o acompanhamento contínuo do mesmo indivíduo ao longo do tempo. Portanto ainda existe pouco conhecimento sobre a dinâmica dos processos fisiológicos e fisiopatológicos da polpa e região periodontal. Assim tem sido lançadas muitas hipóteses das possiveis razões das alterações de fluxo observadas. Na seqüência são exploradas algumas explicações possiveis das alterações apresentadas no capitulo anterior, considerando o conhecimento atual acerca da fisiologia e fisiopatologia da polpa. 


\subsubsection{Inflamação neurogênica da polpa seguida por elevação da pressão tissular}

Num processo inflamatório pulpar, a possibilidade de a pressão intersticial pulpar (PIP) aumentar até provocar a compressão de vasos sangüineos, Kim (1990), foi suportada por evidências de respostas bifásicas (aumento seguido de decréscimo) a drogas vasodilatadoras, Kim et al. (1988), Kim e Dorscher-Kim (1989), Kim (1990). Mas esta possibilidade encontra barreiras quando há evidências de fluxo pulpar e pressão intersticial estão aumentados simultaneamente. Em adição, a hipótese de a pressão tissular aumentada comprimir vasos na polpa não explica o fluxo aumentado no terceiro e no sétimo dias após aplicada a força mecânica, no experimento realizado por VandevskaRadunovic et al. (1994), já citado no Capítulo 3.

Uma explicação possivel e contrária à precedente (de diminuição de fluxo devido a compressão dos vasos), é a possibilidade do sistema de drenagem linfático remover o fluido intersticial, e ou a possibilidade de ocorrer a reabsorção do fluido pelos capilares próximos. Ambos os mecanismos impediriam a elevação da pressão tissular. Esta especulação encontrou suporte quando o fluxo pulpar de dentes de gatos, medido via FLD, e a pressão intersticial da polpa, medida usando a micropuntura (capilar-sensor de vidro), aumentaram juntos. quando fibras nervosas da polpa foram eletricamente estimuladas, resultando (presumivelmente) uma inflamação neurogênica, Heyeraas e Kvinnsland (1992) e Heyeraas et al. (1994). Quando o fluxo pulpar aumentou ocorreu quase instantaneamente aumento da PIP. Mas, alguns minutos depois, a PIP decresceu a niveis até menores que $\circ$ basal. Fundamentados nos resultados obtidos, Heyeraas e Kvinnsland (1992) sugeriram que o curso de um processo inflamatório pulpar nāo resulta a redução, mas sim o aumento de fluxo, seguindo um curso mais favorável à reparação da polpa. No entanto, Pashley (1992) questionou a validade da técnica usada (micropuntura), pois requer a exposição da polpa, e pode ocorrer perda de fluido. Um dos autores mais tarde citou que a elevada dispersão de valores de PIP na literatura pode ser resultante do deslocamento de fluido durante a medição, Heyeraas e Berggren (1999). Outro fator a ser considerado é a ainda polêmica existência de vasos linfáticos na polpa. Embora vasos linfáticos tenham sido reconhecidos na polpa usando técnicas histológicas, 
imuno-histológicas, microscopia eletrônica e de fluorescência, Pimenta et al. (2003), o reconhecimento é dificil e a existência de marcadores específicos ainda é discutida.

Mesmo considerando a existência de vasos linfáticos na polpa, e que mecanismos de reabsorção via capilares próximos (aos que estão com permeabilidade aumentada, na região inflamada) sejam efetivos na polpa, aqui se coloca a seguinte questão: se a força mecânica é suficiente para estrangular vasos sangüíneos na região apical do dente, que possuem pressões maiores que as dos vasos linfáticos, não seriam estes também afetados? Esta possibilidade é explorada mais adiante. Aqui somente consideremos que a ocorrência de um processo inflamatório regional é possível, alterando a permeabilidade das paredes dos vasos sangüíneos numa região, pois inflamações confinadas em pequenas regiōes da polpa têm sido observadas, pelo menos quando o agente causador é um microorganismo (Heyeraas et al., 1994). Neste caso, na região inflamada há um desequilibrio entre as pressões dos vasos sangüíneos e intersticiais, resultando aumento da pressão intersticial pulpar, mesmo que regional. Nesta condição de desequilibrio a reabsorção do fluido intersticial por capilares próximos e drenagem linfática são insuficientes, aumentando a quantidade de fluido $e$ soluto intersticial. No entanto, mesmo num tecido com alta compliância, geralmente o edema não cresce indefinidamente, e um novo equilibrio é alcançado, mas com PIP superior à normal. Numa região, caso ocorra o aumento crescente da PIP, os vasos linfáticos e vênulas seriam comprimidos antes que as arteríolas, resultando hiperemia passiva. Hiperemia passiva significa redução de fluxo sangüíneo (e possibilidade de hipóxia), que é o caso visualizado em ratos sujeitos a forças intrusivas, usando microscopia vital (detalhes na Subseção 6.4.2). Neste mesmo cenário, caso ocorra estrangulamento de vasos linfáticos $e$ ou vênulas eferentes do forâmen apical, um resultado provável também seria a hiperemia passiva. Note-se que embora um conceito comum sobre a inflamação seja a ocorrência de aumento de fluxo (e calor), há evidências contrárias. Estudos da dinâmica do processo inflamatório no tempo e no espaço são raros, e quase sempre limitados à pele. Mas, como um exemplo, um processo inflamatório experimental, induzido por histamina, monitorado no espaço e no tempo usando imagens Doppler do fluxo (Varredura Laser Doppler), revela que o fluxo aumenta com o tempo e avança nas regiões circunvizinhas à estimulada, mas numa região 
central, onde ocorreu o estímulo, o fluxo permaneceu baixo, Clough et al. (2002). Assim nem sempre, no tempo e no espaço, inflamação significa aumento de fluxo. Mas é razoável supor que a dinâmica do processo inflamatório dependa da amplitude e duração do insulto, do tecido e das respostas individuais dentre outros fatores. Neste sentido, as modernas técnicas não invasivas de medição de fluxo irão possibilitar estudos da dinâmica do processo.

$\mathrm{Na}$ polpa com fluxo aumentado decorrente de fatores pró-inflamatórios, caso ocorra redução da PIP, seguindo o processo sugerido por Heyeraas e Kvinnsland (1992), ocorreria hiperemia ativa, com fluxo sangüíneo permanecendo aumentado após o incremento inicial. No entanto Derringer et al. (1996) encontraram evidências da existência de fatores de crescimento associados à neovascularização em polpas de dentes humanos submetidos a forças ortodônticas entre $0,5 \mathrm{~N}$ a 1,5 $\mathrm{N}$ durante cinco dias. Villa et al. (2004) observaram novos vasos sangüineos em polpas de dentes humanos submetidos a forças intrusivas de 1,14 $\mathrm{N}$ durante 8 semanas. Ocorre que a neo-angiogênese está geralmente associada à hipóxia, Chang et al. (1996). Assim é possivel ocorrer redução de fluxo na polpa inflamada (hipótese já conhecida) e há evidências suportando esta hipótese (ainda não relacionadas na literatura). No entanto, também é possível ocorrer edema sem a ocorrência de um processo inflamatório, e esta possibilidade é discutida na seqüência.

$\mathrm{Na}$ polpa. por estar enclausurada entre paredes rigidas, a pressão intersticial pulpar aumenta quando o volume sangüíneo aumenta ou quando o volume do fluido intersticial aumenta. Por ser um sistema de baixa compliância, pequenas variaçōes no volume significam elevadas variaçōes na pressão. A possibilidade de regulagem da pressão tissular mantendo-a ao nivel basal quando ocorre aumento de fluxo, segundo Heyeraas e Kvinnsland (1992), requer - sistema linfático e a reabsorção capilar respondendo fisiologicamente mesmo que ocorra inflamação. Mas em condições normais, as pressões (hidrostática e osmótica) nos capilares, interstício e vasos linfáticos estão balanceadas: numa região o fluxo total aferente é igual ao total eferente. Assim qualquer excesso de fluido intersticial é reabsorvido pelos capilares e drenado pelos vasos linfáticos. Um edema é geralmente caracterizado pelo desbalanceamento das pressões: pressão intersticial acima da normal. Uma das razões a este quadro alterado é a inflamação, quando a permeabilidade vascular à proteina plasmática está 
aumentada. Outras razões do desbalanceamento entre as trocas são: i) obstrução venular; ii) constrição venular e iii) dilatação arteriolar. A constrição ou a obstrução venular na região radicular, resultante do deslocamento dentário, é uma possibilidade. Assim seria possivel o aumento da PIP sem que ocorra efetivamente inflamaçāo. Esta possibilidade é mais adiante explorada. Aqui, coloca-se a seguinte reflexão: o balanço entre as pressões (PIP e vasos) ocorre em condições normais. Mas num processo inflamatório não há balanço e o resultado é o aumento da pressão tissular. No processo induzido por Heyeraas e Kvinnsland (1992), se fosse inflamatório, o balanço entre as pressões PIP, capilar e linfática estaria comprometido pelo aumento da permeabilidade vascular. Nestas condições não seriam possíveis a reabsorção via capilares e a absorção via linfáticos com taxas normais ou mesmo adaptadas, resultando edema, que é o quadro que geralmente é observado em processos inflamatórios. Talvez o processo simulado por Heyeraas e Kvinnsland (1992) não tenha resultado uma inflamação neurogênica, pois não provocou um desbalanceamento pronunciado entre a PIP e a dos vasos controladores (a PIP aumentou assim que o fluxo pulpar aumentou, mas a PIP decresceu alguns minutos após, enquanto o fluxo sangüíneo permaneceu aumentado). Portanto, ou houve perda de fluido intersticial ou não ocorreu um processo inflamatório (houve apenas exsudação líquida devido ao aumento da pressão vascular). Neste último caso a diminuição do fluxo decorreu dos processos normais de reabsorção e absorção, via capilares e linfáticos.

Contudo os experimentos realizados por Heyeraas e Kvinnsland (1992) e Heyeraas et al. (1994) ocorreram fora do contexto de um deslocamento dentário e, portanto não houve compressão dos vasos sangüíneos e linfáticos na região apical. Caso haja compressão dos vasos, por ação do deslocamento dentário, pode ocorrer aumento da resistência desses vasos. Evidências sobre esta possibilidade são discutidas na seqüência, pois coincidem com a discussão seguinte, mas aqui é conjecturado apenas que uma conseqüência possível do aumento da resistência desses vasos é a diminuição do fluxo sangüíneo e linfático. Como uma conseqüência, caso haja compressão dos vasos aferentes do dente, mesmo que haja um processo inflamatório pulpar, considerando as evidências encontradas que sugerem hipóxia, incluindo as encontradas no 
presente trabalho, tais processos resultariam redução de fluxo, pois a drenagem linfática e o retorno vascular estariam com resistências aumentadas.

\subsubsection{Compressão vascular na raiz dental}

A queda de fluxo observada no presente trabalho, imediatamente após a aplicação de forças sugere constrição de vasos que adentram e ou que saem do forâmen apical, pela ação do deslocamento dentário. Quando vasos aferentes estão estrangulados, aumenta a resistência arteriolar e o fluxo decresce. Quando os vasos eferentes estão constringidos a resistência venular está aumentada. Assim, nestes dois cenários o fluxo aferente está diminuido (isquemia) e ou o fluxo eferente está diminuido (hiperemia passiva). Ambos quadros levam à diminuição do fluxo sangüíneo e eventualmente à hipóxia.

Observações diretas (microscopia vital) em incisivos de ratos submetidos a forças intrusivas fornecem algumas informações sobre as alterações vasculares ocorridas: em alguns animais a velocidade de fluxo estava diminuída nos vasos mais largos (supostamente vênulas) e em outros animais ocorreu total estase (Guevara e McClugage, 1980). Embora a força aplicada neste experimento tenha sido extremamente elevada $(0,8 \mathrm{~N})$, outras observações relatadas indicam ausência de outras alteraçōes vasculares, exceto diminuiçāo da velocidade das hemácias nas vênulas: estes dois fatos combinados sugerem aumento da resistência venular, provavelmente devido ao estrangulamento de vasos eferentes. Neste caso pode ter ocorrido hiperemia passiva. A estase relatada em alguns animais, no entanto, sem outra observação complementar pode sugerir compressão de arteriolas e ou de vênulas na região apical. Note-se, no entanto, que uma força de $0,8 \mathrm{~N}$ em ratos significa forças entre $8 \mathrm{~N}$ a $40 \mathrm{~N}$ em humanos, considerada a proporção entre as áreas da raiz dental de ratos e de humanos (na ordem de 10 a 50 vezes), Bohl (2004). Assim poderia ter ocorrido uma ou as duas situações, a depender do animal e da magnitude e área de ação da força efetivamente aplicada a cada animal.

Observações em cortes histológicos de dentes humanos submetidos a forças intrusivas entre $0,35 \mathrm{~N}$ a $2,5 \mathrm{~N}$ durante 3 a 35 dias não sugeriram respostas inflamatórias, mas foram encontradas evidências de alterações vasculares que não dependeram do dia da observação (após a força aplicada) e 
da força, embora a severidade das alterações fosse relacionada à magnitude da força. Forças acima de 1,5 N resultaram invariavelmente hipertrofia endotelial, eritrócitos alterados dentro e fora de vasos sugerindo estase e número aumentado de capilares na regiāo odontoblástica (Stenvik e Mjör, 1970). Neste cenário a inflamação não era evidente, mas ainda assim hiperemia passiva e ou isquemia eram possiveis.

\subsection{Considerações sobre os movimentos e sessões investigadas}

Durante as duas sessões subseqüentes ao dia em que foram ativadas as forças, ou seja, $48 \mathrm{~h}$ e $72 \mathrm{~h}$, nos dois movimentos há predominância de queda crescente de fluxo pulpar nos grupos estudados e há evidências estatisticas no nivelamento que este comportamento pode ser estendido à população donde as amostras foram colhidas. A queda crescente de fluxo neste período pode significar um processo inflamatório ou somente um edema associado à compressão dos vasos na região radicular, pois a possibilidade de ter ocorrido somente compressão crescente dos vasos é remota. Ou seja, no nivelamento o fio usado era superelástico, resultando forças aproximadamente constantes. $\mathrm{Na}$ retração, o material usado era elástico, mas neste caso a força tende a decrescer durante o movimento. Assim são mais prováveis as primeiras possibilidades.

$\mathrm{Na}$ fase de nivelamento o fluxo retornou a níveis próximos ao inicial em 30 dias, sugerindo que o período de reativação das forças, de 30 dias, é adequado, supondo que fluxo próximo ao normal significa recuperação da polpa. Mas na retração, 30 dias após, o fluxo ainda estava abaixo dos níveis iniciais, sugerindo que a polpa ainda não estava recuperada. Assim a reativação neste periodo (30 dias) com o aparelho usado (retração) pode ser outro tema de trabalhos futuros.

\subsection{Considerações adicionais}

A inflamação neurogênica do periodonto, induzida pela estimulação de fibras sensoras, foi conjecturada há pouco mais de uma década. Mas até o presente momento não há provas diretas que nervos imunorreativos a neuropeptídeos controlem a inflamação. As evidências encontradas até agora são o aumento de fibras nervosas imunorreativas a uma quantidade ainda crescente 
de agentes vasoativos, quando estimuladas, coincidentes com mudanças celulares, encontradas em movimentos experimentais de dentes, VandveskaRadunovic (1999).

Ainda, enquanto há evidências concordantes que uma inflamação pulpar pode induzir um processo inflamatório no periodonto, o contrário ainda é controverso, Lundy e Linden (2004). Assim ainda não está claro se todo complexo polpa, LPD e gengiva respondem como um conjunto, conforme sugerido por Hamilton e Gutmann (1999).

Neste sentido, um movimento experimental em molares de ratos resultou aumento na densidade de fibras nervosas imunorreativas a substâncias vasoativas (CGRP e Protein Gene Product) na polpa (e LPD) e de vasos sangüíneos no sétimo dia após aplicada a força, enquanto no terceiro, décimo quarto e vigésimo dias não houve diferença relativa ao controle, VandveskaRadunovic et al. (1997). O aumento de fibras nervosas imunorreativas a substâncias vasoativas na polpa foi interpretado pelos autores como evidência de participação das substâncias vasoativas no processo inflamatório neurogênico. Mas aqui se coloca outra reflexão: o aumento de vasos no sétimo dia poderia ser resultado de hipóxia, e acompanhando a neo-vascularização ocorreria neoneurogênese. Ainda, o modelo (animal) e forças aplicadas foram os mesmos já descritos anteriormente (Vandveska-Radunovic et al., 1997), onde a força aplicada foi demasiadamente elevada (já comentado acima), significando que as alterações observadas não condizem com a prática clínica em humanos.

Assim no presente momento ainda existe a seguinte dúvida: o movimento dentário ortodôntico pode provocar inflamação pulpar? Mais uma vez, pela dificuldade de acesso, os sinais visuais da inflamação não podem ser observados. Das evidências indiretas relatadas na literatura (ver revisão abrangente em Vandveska-Radunovic et al., 1999), não está clara a existência de provas diretas de que há inflamação. Resta, portanto, neste momento um sinal clínico da inflamação: a dor. No entanto, é conhecido que há inervação comum no LPD, polpa e gengiva (Hildebrand et al., 1995), dificultando a identificação da origem da dor. Ainda, tem sido relatado que uma pulpite pode ocorrer sem dor: um estudo recente sugere que aproximadamente $39 \%$ dos casos são indolores, Michaelson e Holland (2002). Ainda, quando ocorre, a dor relatada (ver Michaelson e Holland, 2002) nem sempre pode ser distinguida da dor ou incomodo resultante do 
tratamento ortodôntico (ver Hall e Free, 1998, e Bergius et al., 2002). Agravando a incerteza, a isquemia da polpa diminui a sensibilidade das fibras A-delta, Olgart (1996). Estendendo esta observação ao presente estudo, uma eventual isquemia ou hipóxia pulpar pode diminuir a sensibilidade das fibras A-delta, dificultando ainda mais detectar a pulpite num tratamento ortodôntico.

\subsection{Conclusões do capítulo}

As discussōes acima foram mantidas num nível mínimo de detalhes, buscando sempre ser concisas e expressando somente a lógica desejada. Notoriamente a maioria dos assuntos acima abordados são ainda controversos, muitas vezes apresentando evidências contrárias. Contudo a literatura apontada é seleta e oferece suporte abundante às discussões.

Em adição aos assuntos abordados, é patente que as seguintes áreas ainda carecem conhecimento: anatomia, fisiologia e fisiopatologia da polpa. No estágio atual do conhecimento, um processo inflamatório ainda é descrito como uma seqüência de eventos. No entanto, é razoável supor que existam bifurcações ao longo dos eventos, cujos cursos ainda não são entendidos ou previsíveis. Num plano paralelo, num tratamento ortodôntico provavelmente existem bifurcações. Assim, quando observamos os dados obtidos no presente trabalho, não podemos concluir simplesmente que, nas condições do experimento, houve queda de fluxo no segundo e terceiro dia, como um exemplo. Devemos também observar que alguns dentes apresentaram fluxo aumentado nestes dias, e que tal comportamento não significa necessariamente um erro de medição ou ausência de controle no experimento, mas sim uma possibilidade.

Assim, as discussões poderiam ser orientadas no sentido de tentar explicar os resultados apresentados no capítulo anterior, numa forma restrita, à luz do conhecimento atual. Mas aqui somente é sugerido que há a possibilidade de ter ocorrido inflamação pulpar em alguns casos, noutros não, assim como pode ter ocorrido compressão de vasos na região apical de alguns dentes, noutros não. 0 fato é que, tomando como base a literatura citada ao longo deste texto como um todo, este trabalho é mais completo em relação aos demais, no tocante não somente à técnica usada (fluxometria laser Doppler), como a compreensão da 
quantidade medida (fluxo) e finalmente quanto a interpretação dos resultados, face às possiveis razões que originaram os resultados.

As diversas questões levantadas ao longo deste capitulo são potenciais temas a futuras investigações. Neste sentido, outras técnicas vindouras que permitam avaliar o fluxo pulpar sem altera-lo e com maior capacidade de discriminação espacial serão valiosas. A tomografia por coerência óptica è uma técnica promissora para esta finalidade, e está sendo adaptada a este propósito atualmente no lpen. 


\section{CONCLUSÃO}

Durante os movimentos predominantes de inclinação e translação, correspondentes às fases de nivelamento e retração, estudados em pacientes com maloclusões Classe II, Subdivisão I de Angle, submetidos ao tratamento ortodôntico com aparelho fixo, usando fios superelásticos no nivelamento e arcos dupla chave de aço na fase de retração, ocorreram alterações nos fluxos sangüineos pulpares (FSP) dos incisivos superiores centrais nos grupos estudados, quando medidas usando a fluxometria laser Doppler e dentro das condições de medições e análise dos dados obtidos.

Analisando os dados obtidos, foram encontradas as seguintes principais evidências estatisticas nas alterações de FSP:

- Aos vinte minutos, quarenta e oito horas e setenta e duas horas depois de aplicadas as forças houve decréscimo acentuado do FSP em ambos os grupos;

- Aos trinta dias depois de aplicadas as forças, na fase de nivelamento o FSP é próximo ou igual ao FSP antes do tratamento, e permanece menor que o inicial na fase de retração. 


\section{APENDICE A: VALORES DE FLUXO}

TABELA A5.1: Valores de fluxo, $F(U A)$, de 12 incisivos (N1 a N12) em (UA), medidos durante a fase de nivelamento nas sessões $0 \mathrm{~min}, 20 \mathrm{~min}, 48 \mathrm{~h}, 72 \mathrm{~h}$ e 1 mês após aplicadas as forças.

\begin{tabular}{lccccc}
\hline Nivelamento & \multicolumn{5}{c}{ Fluxo (UA) } \\
& \multicolumn{5}{c}{ F(UA) } \\
\hline Paciente & 0 min & 20 min & $48 \mathrm{~h}$ & $72 \mathrm{~h}$ & 1 mês \\
\hline N1 & 12 & 2,7 & 3,2 & 1,5 & 9,9 \\
N2 & 8,2 & 2,2 & 2,1 & 2,4 & 12 \\
N3 & 23,2 & 16,2 & 6,2 & 6,6 & 16,3 \\
N4 & 13,4 & 10,3 & 11,8 & 4,1 & 10,7 \\
N5 & 10,7 & 7,2 & 7 & 5,8 & 14 \\
N6 & 15,3 & 13,5 & 9,9 & 6,5 & 14,1 \\
N7 & 12,7 & 12,3 & 5,1 & 7 & 6,6 \\
N8 & 9,5 & 11,3 & 10,9 & 1,7 & 5,9 \\
N9 & 13,2 & 8,5 & 11,8 & 13,4 & 18,5 \\
N10 & 10 & 5,1 & 3,6 & 3,1 & 14,7 \\
N11 & 15,5 & 5,1 & 5,7 & 3,6 & 9,9 \\
N12 & 12,6 & 3,4 & 3 & 3,5 & 14,8 \\
& & & & & \\
Mediana & 12,6 & 7,2 & 5,7 & 3,6 & 12 \\
Média & 13 & 8,2 & 6,7 & 4,9 & 12,3 \\
Desvio Padrão & 3,9 & 4,6 & 3,6 & 3,3 & 3,8 \\
Fluxo Minimo & 8,2 & 2,2 & 2,1 & 1,5 & 5,9 \\
Fluxo Máximo & 23,2 & 16,2 & 11,8 & 13,4 & 18,5 \\
\hline & & & & & \\
& & & & & \\
& 10,3 &
\end{tabular}


TABELA A5.2: Valores de variações percentuais de fluxo, $F(\%)$, de 12 incisivos ( $N 1$ a N12) em (\%), medidos durante a fase de nivelamento nas sessōes 0 min, 20 min, 48h, $72 h$ e 1 mês após aplicadas as forças.

\begin{tabular}{lccccc}
\hline Nivelamento & \multicolumn{5}{c}{ Variação percentual de fluxo (\%) } \\
& \multicolumn{5}{c}{$F(\%)$} \\
\hline Paciente & 0 min. & 20 min. & $48 \mathrm{~h}$ & $72 \mathrm{~h}$ & 1 mês \\
\hline N1 & 100 & 22,5 & 26,7 & 12,5 & 82,5 \\
N2 & 100 & 26,8 & 25,6 & 29,3 & 146,3 \\
N3 & 100 & 69,8 & 26,7 & 28,4 & 70,3 \\
N4 & 100 & 76,9 & 88,1 & 30,6 & 79,9 \\
N5 & 100 & 67,3 & 65,4 & 54,2 & 130,8 \\
N6 & 100 & 88,2 & 64,7 & 42,5 & 92,2 \\
N7 & 100 & 96,9 & 40,2 & 55,1 & 52 \\
N8 & 100 & 118,9 & 114,7 & 18,2 & 62,1 \\
N9 & 100 & 64,4 & 89,4 & 101,5 & 140,2 \\
N10 & 100 & 51 & 36 & 31 & 147 \\
N11 & 100 & 32,9 & 36,8 & 23,2 & 63,9 \\
N12 & 100 & 27 & 23,8 & 27,8 & 117,5 \\
& & & & & \\
Mediana & 100 & 64.4 & 36.8 & 29.3 & 82.5 \\
Média & 100 & 61,9 & 53,2 & 37,9 & 98,7 \\
Desvio Padrão & 0 & 30,8 & 30,7 & 23,8 & 35,6 \\
Fluxo Minimo & 0 & 22,5 & 23,8 & 12,5 & 52 \\
Fluxo Máximo & 0 & 118,9 & 114,7 & 101,5 & 140,2 \\
\hline
\end{tabular}


TABELA A5.3: Valores de diferenças entre fluxos, $F$ (dif), de 12 incisivos (N1 a N12) em (UA), medidos durante a fase de nivelamento nas sessões 0 min, 20 min, $48 \mathrm{~h}, 72 \mathrm{~h}$ e 1 mês após aplicadas as forças.

\begin{tabular}{lccccc}
\hline Nivelamento & \multicolumn{5}{c}{ Diferença entre Fluxos (UA) } \\
\hline Paciente & 0 min. & 20 min. & $48 \mathrm{~h}$ & $72 \mathrm{~h}$ & 1 mês \\
\hline N1 & 0 & $-9,3$ & $-8,8$ & $-10,5$ & $-2,1$ \\
N2 & 0 & -6 & $-6,1$ & $-5,8$ & 3,8 \\
N3 & 0 & -7 & -17 & $-16,6$ & $-6,9$ \\
N4 & 0 & $-3,1$ & $-1,6$ & $-9,3$ & $-2,7$ \\
N5 & 0 & $-3,5$ & $-3,7$ & $-4,9$ & 3,3 \\
N6 & 0 & $-1,8$ & $-5,4$ & $-8,8$ & $-1,2$ \\
N7 & 0 & $-0,4$ & $-7,6$ & $-5,7$ & $-6,1$ \\
N8 & 0 & 1,8 & 1,4 & $-7,8$ & $-3,6$ \\
N9 & 0 & $-4,7$ & $-1,4$ & 0,2 & 5,3 \\
N10 & 0 & $-4,9$ & $-6,4$ & $-6,9$ & 4,7 \\
N11 & 0 & $-10,4$ & $-9,8$ & $-11,9$ & $-5,6$ \\
N12 & 0 & $-9,2$ & $-9,6$ & $-9,1$ & 2,2 \\
& & & & & \\
Mediana & 0 & $-4,9$ & -6.4 & $-8,8$ & $-2,1$ \\
Média & 0 & $-4,9$ & $-6,3$ & $-8,1$ & $-0,7$ \\
Desvio Padrão & 0 & 3,7 & 4,8 & 4,1 & 4,4 \\
Fluxo Mínimo & 0 & $-0,4$ & 1,4 & 0,2 & 4,7 \\
Fluxo Máximo & 0 & $-10,4$ & $-9,8$ & $-16,6$ & $-6,1$ \\
\hline & & & & &
\end{tabular}


TABELA A5.4: Valores de fluxo, $F(U A)$, de 13 incisivos (R1 a R13) em (UA), medidos durante a fase de retração nas sessões 0 min, 20 min, 48h, 72h, 1 mês e 45 dias após aplicadas as forças.

\begin{tabular}{lcccccc}
\hline Retração & \multicolumn{5}{c}{ Fluxo (UA) } \\
Pacientes & 0 min & 20 min & 48 h & $72 \mathrm{~h}$ & 1 mês & 45 dias \\
\cline { 2 - 7 } R1 & 12,1 & 5,6 & 10,2 & 6,9 & 3,9 & 4,7 \\
R2 & 21,5 & 13,4 & 16,4 & 11,1 & 17,5 & X \\
R3 & 12,7 & $x$ & 7,7 & 3,6 & 5 & X \\
R4 & 13,8 & 16,8 & 15,9 & 9,2 & 13,3 & 11,1 \\
R5 & 14,9 & 19,4 & 3,5 & 4 & 4,1 & X \\
R6 & 11,2 & 6.8 & 6,2 & 4,9 & 6,2 & X \\
R7 & 3,8 & 3,2 & 4,1 & 4,7 & 4,2 & 4,4 \\
R8 & 4,3 & 3,6 & 2,1 & 2,9 & 3,5 & X \\
R9 & 4,3 & 2,4 & 4,3 & 2,2 & 3 & 6,7 \\
R10 & 3,5 & 2,8 & 1,2 & 0,8 & 1,5 & 3,9 \\
R11 & 9,3 & 5,1 & 5,8 & 4,7 & 6,1 & 8,5 \\
R12 & 9,8 & 1 & 2 & 9,6 & 1,4 & 3,4 \\
R13 & 7,8 & 2.7 & 4,9 & 6,3 & 8,3 & 7,3 \\
& & & & & & \\
Mediana & 9.5 & 3.6 & 4.6 & 4.7 & 4.15 & 4.7 \\
Média & 9,9 & 6.9 & 6,5 & 5,4 & 6 & 6,2 \\
Desvio Padrão & 5,3 & 6,2 & 4,9 & 3,1 & 4,7 & 2,7 \\
Fluxo mínimo & 3,5 & 1 & 1,2 & 0,8 & 1,4 & 3,4 \\
Fluxo máximo & 21,5 & 19,4 & 16,4 & 11,1 & 17,5 & 11,1 \\
\hline
\end{tabular}


TABELA A5.5: Valores de variações percentuais de fluxo, $F(\%)$, de 13 incisivos (R1 a R13) em (\%), medidos durante a fase de retração nas sessões 0 min, 20 min, $48 \mathrm{~h}, 72 \mathrm{~h}, 1$ mês e 45 dias após aplicadas as forças.

\begin{tabular}{lcccccc}
\hline Retração & \multicolumn{5}{c}{ Variação percentual de fluxo (\%) } \\
Paciente & O min & 20 min & $48 \mathrm{~h}$ & $72 \mathrm{~h}$ & 1 mês & 45 dias \\
\hline R1 & 100 & 46,1 & 84,6 & 57,2 & 31,8 & 38,5 \\
R2 & 100 & 62,4 & 76,4 & 51,6 & 81,6 & $\mathrm{x}$ \\
R3 & 100 & $\mathrm{X}$ & 60,6 & 28,2 & 39,1 & $\mathrm{x}$ \\
R4 & 100 & 121,6 & 115,2 & 66,5 & 96,5 & 80,5 \\
R5 & 100 & 130,6 & 23,4 & 27 & 27,4 & $\mathrm{x}$ \\
R6 & 100 & 60,1 & 54,8 & 43,8 & 54,9 & $\mathrm{x}$ \\
R7 & 100 & 85,1 & 106,7 & 122,5 & 110,5 & 115,4 \\
R8 & 100 & 83,9 & 50,1 & 67 & 81 & $\mathrm{x}$ \\
R9 & 100 & 54,4 & 100 & 50,3 & 69 & 153,5 \\
R10 & 100 & 81 & 35,1 & 22,3 & 43,4 & 112,3 \\
R11 & 100 & 54,8 & 62,6 & 50,4 & 65,2 & 91,7 \\
R12 & 100 & 10,2 & 20,8 & 97,3 & 14,7 & 34,4 \\
R13 & 100 & 34,4 & 63,6 & 80,4 & 106,6 & 93,4 \\
& & & & & & \\
Mediana & 100 & 60.1 & 61.6 & 51 & 60.05 & 91.7 \\
Média & 100 & 68,7 & 65,7 & 58,8 & 63,2 & 90 \\
Desvio Padrão & 0 & 34,3 & 30,2 & 28,6 & 31,1 & 39,7 \\
Mínimo & 100 & 46,1 & 84,6 & 57,2 & 14.7 & 34.4 \\
Máximo & 100 & 130.6 & 115.2 & 122.5 & 110.5 & 153.5 \\
\hline & & & & & &
\end{tabular}


TABELA A5.6: Valores de diferenças entre fluxos, $F$ (dif), de 13 incisivos (R1 a R13) em (UA), medidos durante a fase de retração nas sessões 0 min, 20 min, $48 \mathrm{~h}, 72 \mathrm{~h}, 1$ mês e 45 dias após aplicadas as forças.

\begin{tabular}{|c|c|c|c|c|c|c|}
\hline \multirow{3}{*}{$\begin{array}{l}\text { Retração } \\
\text { Paciente }\end{array}$} & \multicolumn{6}{|c|}{ Diferença entre fluxos (UA) } \\
\hline & \multicolumn{6}{|c|}{$F($ dif $)$} \\
\hline & $0 \min$ & $20 \mathrm{~min}$ & $48 \mathrm{~h}$ & $72 \mathrm{~h}$ & $1 \mathrm{~m}$ & 45 dias \\
\hline$\overline{\mathrm{R} 1}$ & 0 & $-6,5$ & $-1,9$ & $-5,2$ & $-8,3$ & $-7,4$ \\
\hline R2 & 0 & $-8,1$ & $-5,1$ & $-10,4$ & -4 & $x$ \\
\hline R3 & 0 & $x$ & -5 & $-9,1$ & $-7,8$ & $x$ \\
\hline R4 & 0 & 3 & 2,1 & $-4,6$ & $-0,5$ & $-2,7$ \\
\hline R5 & 0 & 4,6 & $-11,4$ & $-10,9$ & $-10,8$ & $x$ \\
\hline R6 & 0 & $-4,5$ & $-5,1$ & $-6,3$ & $-5,1$ & $x$ \\
\hline R7 & 0 & $-0,6$ & 0,3 & 0,9 & 0,4 & 0,6 \\
\hline $\mathrm{R} 8$ & 0 & $-0,7$ & $-2,1$ & $-1,4$ & $-0,8$ & $x$ \\
\hline R9 & 0 & -2 & 0 & $-2,2$ & $-1,3$ & 2,3 \\
\hline R10 & 0 & $-0,7$ & $-2,3$ & $-2,7$ & -2 & 0,4 \\
\hline R11 & 0 & $-4,2$ & $-3,5$ & $-4,6$ & $-3,2$ & $-0,8$ \\
\hline $\mathrm{R} 12$ & 0 & $-8,8$ & $-7,8$ & $-0,3$ & $-8,4$ & $-6,4$ \\
\hline R13 & 0 & $-5,1$ & $-2,8$ & $-1,5$ & 0.5 & $-0,5$ \\
\hline Mediana & 0 & -4.2 & -3.15 & -4.6 & -3.6 & $-0,8$ \\
\hline Média & 0 & $-2,8$ & $-3,4$ & $-4,5$ & $-3,9$ & $-1,8$ \\
\hline Desvio Padrão & 0 & 4,2 & 3,6 & 3,8 & 3,8 & 3,5 \\
\hline Minimo & 0 & -8.8 & -11.4 & -10.9 & -10.8 & $-7,4$ \\
\hline Máximo & 0 & 4.6 & 2.1 & 0.9 & 0.5 & 2.3 \\
\hline
\end{tabular}




\section{ANEXO A - FORÇAS ORTODÔNTICAS}

As definiçōes, denominações e fios ortodônticos usados na elaboração do presente trabalho são descritos na seqüência.

\section{Forças ortodônticas: definições}

Segundo Paiva et al. (1998) e Smith e Burstone (1984), força é um agente físico capaz de alterar o estado de repouso ou de movimento uniforme de um corpo material.

Pressão é a força por unidade de área que tende comprimir um corpo quando submetido a uma força externa. No sistema MKS expressa em N/m ${ }^{2}$. Na ortodontia é utilizada para representar uma resposta inicial, geralmente no lado oposto ao que o dente foi submetido à aplicação de força (FIG. A3.1).

Tensão é a força por unidade de área que tende a distender um corpo quando é submetido a uma força externa. No sistema MKS é expressa em N/m². $\mathrm{Na}$ ortodontia está relacionada à resposta inicial da ação da força aplicada sobre o dente, geralmente no lado ao que o dente foi submetido à aplicação de força (FIG. A3.1).

Centro de resistência é o centro de massa do dente, ponto pelo qual o corpo sofrerá movimento de translação após a aplicação de uma força.

Denomina-se centro de rotação o ponto em que após a aplicação de uma força o corpo irá inclinar ou girar ao redor do seu longo eixo. 


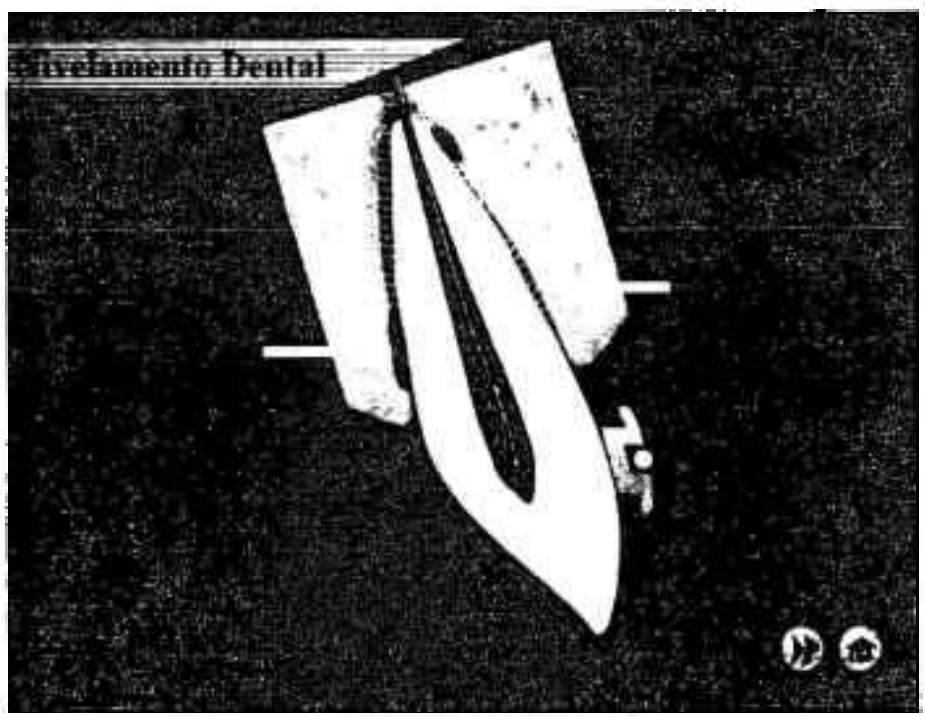

FIGURA A3.1: Desenho de um dente submetido a uma força externa resultando um movimento de rotação em torno do centro de resistência, denominado movimento de inclinação. Como uma conseqüência, no alvéolo surgem áreas comprimidas e distendidas.

\section{Tipos de movimentos dentários}

Os principais movimentos dentários podem ser caracterizados em: i) inclinação, ii) rotação, iii) translação, iv) intrusão e extrusão.

i) o movimento de inclinação ocorre quando a coroa dental desloca-se em um sentido e a raiz no sentido contrário, o centro de resistência dental localiza-se próximo mas não coincide com o centro de rotação.

il) o movimento de rotação dá-se pela movimentação da coroa e raiz no longo eixo dental, o centro de resistência e o centro de rotação localizam-se no mesmo ponto.

iii) o movimento de translação ocorre quando a coroa e raiz deslocam-se no mesmo sentido e possuem a mesma direção. 
iv) o movimento de intrusão e extrusão ocorre quando a coroa e a raiz do elemento dental movimentam-se em seu próprio longo eixo e o centro de rotação localiza-se no infinito.

\section{Ligas de Níquel-Titânio}

As ligas de Niquel-Titânio foram apresentadas pela primeira vez no início dos anos sessenta do século passado pelo engenheiro metalúrgico William $F$. Buehler, que as denominou NITINOL devido aos seus dois principais compostos, - Níquel e o Titânio (NiTi) e em homenagem ao laboratório onde se desenvolveu as pesquisa (Naval Ordinance Laboratory) na cidade de Silver Springs, Maryland, EUA.

Andreasen e Morrow realizaram a primeira aplicação clínica da liga NiTi na área de ortodontia. A liga apresenta uma propriedade singular conhecida como Memória de Forma, resultado de transformações cristalográficas induzidas pela mudança da temperatura sendo extremamente maleável a baixas temperaturas, e quando submetida a variações de temperatura, a liga volta a sua forma original sem apresentar uma deformação permanente.

Miura et al. (1986) introduziram pela primeira vez uma nova geração de fios de níquel-titânio que apresenta a propriedade a qual se descreve como superelasticidade. Denominou-se comercialmente a esta liga como Sentalloy (Super Elastic Niquel Titanium Alloy).

$\mathrm{Na}$ escolha do arco ideal, durante as fases iniciais do tratamento ortodôntico, quando nivelamento e alinhamento são realizados, deseja-se um grande intervalo de ação e liberação de forças, onde são indicados os arcos de Nitinol.

O nitinol pode ser subdividido em três tipos: uma liga convencional e duas ligas superelásticas. Estas últimas podem ser pseudoelásticas ou termoelásticas. O fio Sentalloy é descrito como nitinol termoelástico.

Esta liga de níquel-titânio é uma liga martensítica ativa que exibe efeitos de memória de forma induzida pela temperatura. $O$ efeito de memória de forma é 
a combinação dos efeitos de termoelasticidade e de pseudoelasticidade. A transformação martensítica obedece a faixas de temperatura bem definidas, em função da composição química da liga, de sua história termomecânica e do tratamento térmico sofrido pelo material (Arruda et al., 2003).Com o aumento da temperatura temos a reversão da fase martensítica (entrelaçado hexagonal fechado) para a fase austenítica (corpo cúbico centrado). Quando se dá o resfriamento ocorre o inverso, o fio passa da fase austenítica para a fase martensítica, esta transformação facilita a inserção do fio dentro do slot do bráquete de dentes que estejam muito desalinhados e desnivelados.(Meling et al., 2001; Kusy, 1997).

Após a inserção do arco nos bráquetes do dentes em posiçāo irregular 0 aparelho é ativado pela temperatura da boca do paciente, retornando à sua forma pré-determinada, promovendo o nivelamento e alinhamento dental.

\section{Arco de retração anterior dupla chave (Double Key Hole)}

A retração dos dentes anteriores, com a finalidade de fechar espaços, representa um estágio fundamental em muitos tratamentos ortodônticos. $O$ correto posicionamento dos dentes após a retração, o equilibrio na função mastigatória, estabilidade e estética são alguns dos objetivos procurados.

O Arco de retração anterior dupla chave (Double Key Hole) é construido com fio de aço inoxidável, (no presente trabalho apresentava medidas de 0.19"x 0.25 " e ou 0.021 "x 0.025 "), constitui-se por duas alças de cada lado em forma de buraco de fechadura (Double Key Hole), e ou em forma de "T", (no presente trabalho apresentava medidas de com $4 \mathrm{~mm}$ de altura e $5 \mathrm{~mm}$ de largura), localizando-se na mesial e distal dos caninos. Possibilita fechar os espaços remanescentes de extraçōes dentais com o uso de apenas um arco, além do controle das inclinações axiais durante a retração, fechamento dos diastemas de mesial para distal e ou de distal para mesial e controlar a inclinação dos caninos. A espessura do arco a ser usado depende das necessidades de ancoragem determinadas pelo planejamento inicial do tratamento ortodôntico. 
Segundo Suzuki e Simões (2001) ativação do arco deve ser feita através de um fio de amarrilho 0.025", amarrado ao gancho do primeiro molar até a segunda alça do arco. 


\section{ANEXO B - MOVIMENTAÇÃO ORTODÔNTICA}

A aplicação de uma força ortodôntica sobre um elemento dental resulta forças tridimensionais em toda a região peridental. Embora as forças resultantes possam ser transmitidas a regiões mais remotas, doravante aqui limitamos esta região à matriz óssea alveolar, à gengiva livre e inserida e ao ligamento periodontal. As forças podem resultar compressão ou tensão nos tecidos subjacentes à raiz dental. Outras deformações não são aqui consideradas (e. g., torção, flexão).

$\mathrm{Na}$ literatura diferentes opiniōes podem ser encontradas sobre a quantidade de força que resulta no melhor mecanismo para a realização do movimento ortodôntico dental. Schwarz em 1932 (apud Ren et al., 2003) propôs que o conceito de força ótima seria a força que leva a mudanças na pressão tecidual aproximada à dos vasos sangüineos capilares prevenindo $\circ$ colabamento no lado de compressão do ligamento periodontal. Ou seja, não promoveriam reaçōes no ligamento periodontal, prevenindo reabsorções ósseas frontais. Schwarz sugere ainda que forças excessivas promoveriam áreas de necrose dificultando o movimento dental.

O conceito atual de forças ótimas (Ren et al., 2003) está baseado na hipótese de que a força ideal tem magnitude que associada às suas características temporais (i. e., contínua ou intermitente) seria capaz de promover a taxa máxima de movimento dental sem ocasionar prejuízo ao tecido e com o máximo de conforto ao paciente.

Ao aplicar-se uma força leve ou pesada sobre um dente a tensigridade (resultado do equilibrio de forças interno e externo) será quebrada. $O$ resultado da perda de equilibrio será expresso por respostas químicas.

Quando se aplica a força mecânica entre 1 a 2 segundos o dente se desloca e o fluido do ligamento periodontal é comprimido. Uma compressão induzida pela força mecânica deforma o citoesqueleto celular, modificando a permeabilidade da membrana celular ativando vias metabólicas intracelulares, 
que resultam em liberação de substância que atuam como mediadores capazes de promover alterações celulares e ou vasculares.

Essas substâncias produzidas pelas células são; i) citocinas: interleucina 1, interleucina 2, interleucina 6 e fator de necrose tumoral (TNF); ii) fatores de crescimento: fator de crescimento epidérmico (EGF), fator ativador de fibroblastos e fator de crescimento derivado das plaquetas (PGDF) e; iii) produtos do ácido araquidônico: prostaglandinas e os leucotrienes.

Assim o estresse celular mecânico ocorre pela deformação celular e perda de sua tensigridade.

A movimentação ortodôntica, além de atuar na forma da célula, ao mesmo tempo promove a diminuição de oxigênio desta pela compressão dos vasos sangüíneos do ligamento periodontal, resultando diminuição de nivel de oxigênio, caracterizando-se o estresse celular funcional. Este processo dá-se alguns minutos após a aplicação da força (Profitt, 2000). A modificação iônica da membrana celular implica em um afluxo de íons cálcio para o interior da célula, levando a produção de mediadores que contribuem para o restabelecimento da oxigenação.

O local desses eventos e acúmulo de mediadores é o espaço preenchido pelo ligamento periodontal entre o dente e osso alveolar, onde a força esta agindo diretamente. Todo este conjunto de mecanismos leva o tecido da área a resistir, adaptar-se ou defender-se objetivando eliminar a força, dissipando-a.

Forças aplicadas sobre as células resultam em eventos biológicos reacionais e ou adaptativos. Esta tradução de um evento físico em fenômenos biológicos é denominada mecanotransdução.

Se a célula não conseguir retornar a sua normalidade, evolui para lesões sub letais, e posteriormente à necrose. Na necrose há desintegração celular e tecidual local gerando proteinas livres, que vão desencadear o processo inflamatório.

O ligamento periodontal tem seu volume constituído por $50 \%$ de vasos e morfologicamente são mais fenestrados que um tecido conjuntivo de preenchimento. Além das proteinas livres liberadas pela necrose celular, 0 colabamento dos vasos sangüíneos, oriundo da pressão exercida pela força mecânica do movimento ortodôntico, também pode gerar proteinas livres decorrentes da degradação celular ou da desorganização de fibras colágenas e 
da matriz extracelular (Gaengler e Merte, 1983). Essas proteinas livres atuam sobre os mastócitos do ligamento periodontal que degranulam e liberam histamina, e também agem sobre as terminações nervosas livres, que liberam neuropeptídeos. Esses dois fenômenos desencadeiam a contração das células endoteliais levando a uma vasodilatação e ao aumento da permeabilidade vascular, estabelecendo-se a exsudação plasmática de macromoléculas ou proteínas livres, resultando em um aumento da viscosidade sangüínea e conseqüente diminuição do fluxo sangüíneo (Consolaro, 2002).

Os neutrófilos são os primeiros componentes a chegarem na região devido à sua superior agilidade e atração pelo exsudato, mas não interagem com o agressor (a força mecânica). Os macrófagos fagocitam pequenas e grandes partículas, são produtores de substâncias para o meio extracelular como citocinas, fatores de crescimento e produtos do ácido araquidônico, além de outros importantes mediadores. Assim, o exsudato inflamatório caracteriza-se por um $\mathrm{pH}$ ácido, favorecendo a chegada e permanência de clastos com conseqüente modificação da anatomia alveolar e movimentação dentária. Este processo ocorre ao redor do segundo dia após a aplicação da força mecânica (Consolaro, 2002).

Macroscopicamente, dependendo da magnitude da força aplicada, a resposta no ligamento periodontal será distinta. Uma força leve leva à compressão parcial de vasos sangüíneos no periodonto no lado de pressão e uma dilatação dos vasos no lado de tensão entre 3 a 5 segundos iniciais. Minutos após alterado o fluxo sangüíneo, bem como o nivel de oxigênio, mediadores químicos são liberados. Algumas horas após a aplicação das forças ocorre o início da diferenciação celular no ligamento periodontal e em aproximadamente 2 dias ocorre o movimento dental. Este processo é denominado reabsorção frontal (Profitt, 2000).

Quando uma força denominada pesada é aplicada ao dente, entre 1 a 2 segundos após, o fluido do ligamento periodontal é extravasado e o dente movese no espaço periodontal. Depois de 3 a 5 segundos vasos sangüíneos são totalmente obliterados no lado de pressão levando o fluxo sangüíneo a ser interrompido em poucos minutos. Depois de algumas horas ocorre a morte celular na região comprimida. Entre 3 a 5 dias ocorrem diferenciações celulares nos pequenos espaços adjacentes da área hialinizada dando-se início a reabsorção 
solapante. Neste processo, depois de 7 a 14 dias ocorre o movimento dental (Profitt, 2000). 


\section{ANEXO C - ANATOMIA E FISIOLOGIA DA MICROCIRCULAÇÃO PULPAR}

\section{Anatomia}

O fluxo sangüíneo é bombeado do ventriculo esquerdo, para a aorta, que sofre ramificaçōes, originando a artéria carótida comum. Da artéria carótida comum, o sangue oxigenado penetra na artéria carótida externa, desta passa para artéria maxilar interna onde sofre três divisões: i) mandibular, ii) pterigóide, iii) pterigopalatina.

O ramo pterigopalatino divide-se em artéria infra-orbitária e artéria alveolar superior posterior. A artéria infra-orbitária da origem a artéria alveolar superior anterior fornecendo suprimento sangüíneo aos incisivos centrais e caninos superiores. A artéria alveolar superior posterior fornece o suprimento sangüineo para os pré-molares e molares superiores.

O suprimento arterial dos dentes é derivado de uma ou várias pequenas artérias que penetram a polpa através do forâmem apical, além de inúmeros pequenos vasos que penetrarem através de foraminas laterais. Todo este complexo sistema irriga o dente e seu periodonto.

\section{Fisiologia da microcirculação}

A microcirculação inicia-se nas metarteríolas, passando pelos esfíncteres pré-capilares, capilares, esfíncteres pós-capilares e vênulas. Das metarteríolas e às vezes das arteriolas nascem derivações de vasos, chamadas anastomoses artério-venosas, que comunicam o lado arterial ao lado venoso.

O sistema de filtração capilar ocorre pela passagem de um fluxo, do capilar ao intersticio, de substâncias difusíveis (e. g., água, eletrólitos, aminoácidos) da parede do capilar que se caracterizam por ter um raio molecular reduzido, um peso molecular pequeno e um alto coeficiente de difusão.

Entre os capilares e o interstício forma-se uma pressão de filtração, que facilita a saida de substâncias capilares. A pressão de filtração é a soma da 
pressão hidrostática capilar (PHC), pressão oncótica intersticial e pressão negativa intersticial.

A pressão hidrostática capilar depende da relação entre a massa de sangue e o volume existente no capilar, que está diretamente associada à pressão arterial.

A pressão oncótica ou coleidosmótica é dada pelas capacidades que exercem os colóides (normalmente proteínas plasmáticas) de atrair água. Como essas proteínas podem passar do capilar para o interstício, exercem uma pressão atraindo água para o interstício.

A pressão intersticial negativa é aquela que facilita a passagem de água para o intersticio, sendo aparentemente gerada pela formação da linfa, que atrai liquido para o sistema linfático, e pelo retorno de líquido do interstício para o capilar.

Assim como existe a saída (efluxo) de líquido do capilar, pode ocorrer o processo inverso, ou seja, a entrada (influxo). Na extremidade capilar mais próximo da arteriola a pressão de filtração (efluxo) é maior que a pressão de absorção (influxo). Na extremidade venosa do capilar mais próxima da vênula a pressão de absorção (influxo) é maior que a pressão de filtração (efluxo). Deste modo o líquido sai da extremidade arterial e retorna pela extremidade venosa. Com isso parte do fluxo que sai do capilar retorna ao sangue. Assim o volume plasmático se mantém constante, assim como o volume intersticial. Deve-se ressaltar que entre $10 \%$ a $20 \%$ do fluido intersticial retornam pelo sistema linfático, que se conecta ao lado venoso do retorno sangüíneo.

As trocas são expressas pelas forças de Starling (hipótese) seguindo equação: $P_{C}-P_{1}=\sigma\left(C O P_{P}=C O P_{1}\right)$ onde $P_{C}$ é a pressão capilar, $P_{1}$ é a pressão fluido intersticial, $\mathrm{COP}_{\mathrm{P}}$ é a pressão coleidosmótica no plasma capilar, $\operatorname{COP}_{1}$ é a pressão coleidosmótica no fluido intersticial, e $\sigma$ é coeficiente de reflexão osmótico para proteínas plasmáticas.

\section{Microcirculação pulpar}

A câmara pulpar é extensivamente vascularizada (Hildebrand et al., 1995). Arteriolas com cerca de 50 micrômetros de diâmetro interno entram no canal apical e seguem um caminho direto à polpa coronária. Ao longo dos trajetos, há 
numerosos ramos transformando-se em metarteriolas e capilares, com diâmetros ao redor de 8 micrômetros, que passam perifericamente para formar um plexo na região odontogênica irrigando o plexo de Raschkow. Estes capilares terminam em vênulas que depois se transformam em veias.

O sistema linfático constitui o segundo sistema circulatório cuja primeira função é trazer o líquido intersticial de volta para a corrente sangüínea e controlar os niveis de pressões dentro da polpa (Pimenta e Gómez, 2003).

Todas as células da polpa dental estão envoltas pelo fluido intersticial, sendo dependentes deste fluido para manter-se vivas e funcionar normalmente. O fluido extracelular além da nutrição atua na eliminação de degetos produzido pela célula.

O sangue através dos capilares leva as substâncias necessárias para a manutenção celular, e por difusão os nutrientes são entregues ao fluido intersticial. Os capilares são amplamente distribuidos na polpa dental e nenhuma célula está distante mais de 50 a 100 microns do sistema circulatório. Esta proximidade facilita o processo de difusão. Ou seja, o fluido intersticial é apropriado o bastante para o transporte de nutrientes e a eliminação de degetos entre as células e o sangue capilar.

Como a polpa dental apresenta-se dentro de uma cavidade que não apresenta flexibilidade, alterações no volume de entrada de fluxo do sangue podem acarretar mudanças nos valores da pressão do fluido intersticial, assim um aumento de volume aumenta a pressão do fluido intersticial e vice-versa.

$O$ volume do fluido intersticial pode aumentar: i) pelo aumento do volume sangüineo (devido a um aumento do volume de sangue) e; ii) pelo aumento do volume do fluido intersticial (causado pelo aumento da passagem de fluidos na rede capilar). Assim em uma vasodilatação ou em uma estase venosa ocorre um aumento do volume de sangue comprimindo o tecido pulpar. Existe uma rápida reposta da pressão hidrostática que tende a diminuir a diferença na pressão hidrostática transmural, e conseqüentemente, a filtração capilar reduz ou a absorção inicia-se, de acordo com a equação de Starling. Todo este mecanismo é sutil, pois a polpa em condições normais é capaz de manter-se funcionado em condiçōes de edema e manter o seu volume relativamente estável. 


\section{Atuação do sistema Nervoso Simpático e Parassimpático no controle do fluxo pulpar}

O sistema parassimpático é mediado principalmente pelo neurotrasmissor acetilcolina (Olgart, 1996) que atua promovendo a vasodilatação, e mediado pelo peptídeo vasoativo intestinal (VIP), molécula que, acredita-se, atuar na produção de potentes citocinas antiinflamatórias (Lundy e Linden, 2004). Entretanto, a evidência funcional da regulação do sistema parassimpático no fluxo pulpar ainda é motivo de controvérsia, apesar de receptores e mediadores químicos estarem presentes. A regulação remota parece exercer pequena influência no fluxo sangüíneo e o controle vascular é baixo (Olgart, 1996).

O sistema simpático, por outro lado, apresenta uma atuação mais ativa. Está vinculado principalmente com a manutenção da pressão arterial caracterizando-se pela vasoconstricção das arteriolas na maioria dos tecidos e por efeitos diretos no coração. Na polpa dental foi constatada a presença de adrenoreceptores alfa provendo evidência conclusiva da inervação adrenérgica (Olgart, 1996). Estudos tem mostrado que a vasoconstricção em cães e gatos é mediada por receptores vasculares adrenoceptores tipo $\alpha_{1}$ e $\alpha_{2}$. Ressalta-se que o fluxo sangüíneo na polpa é insignificante frente ao sistema circulatório, mas sofre a ação direta deste sistema.

A ação do sistema simpático relaciona-se com a regulação dos esfíncteres pré e pós-capilares para ajustar a pressão entre os capilares, apesar de não haver descrição detalhada em dentes humanos. Na condição de repouso a ação do sistema simpático no fluxo sangüíneo pulpar é baixa em homens e animais. Sua mediação é dada pela noradrenalina e pelo neuropeptídeo $Y$, potente vasoconstrictor que amplia os efeitos pós sinápticos da noradrenalina (Lundy $e$ Linden, 2004). 


\section{REFERÊNCIAS BIBLIOGRÁFICAS}

1. AKPINAR, K. E.; ER, K.; POLAT, S.; POLAT, T. N. Effect of gingiva on laser Doppler pulpal blood flow measurements, $J$ of Endod., v. 30, n. 3, p. 138140, 2004.

2. ANSTENDIG, H.S.; KRONMAN, J.H. A histologic study of pulpal reaction to orthodontic tooth movement in dogs. Angle Orthod., v. 42, n. 1, p. 50- 55, 1972.

3. ARRUDA, C.C.; PAIVA, J.B.; LIMA, L.P.C.P.; ROSSI,J.L. Análise mecanodinâmica de ligas de níquel-titânio em ortodontia. Ortodontia, v. 36, n.2, p. 57-69, 2003.

4. BAAB, D.A.; OBERG, P.A.; HOLLOWAY, G.A. Gingival blood flow measured with a laser Doppler flowmeter J Periodontal Res., v. 21, n.1, p.73-85, 1986.

5. BARWICK, P. J.; RAMSAY, D. S. Effect of brief intrusive force on human pulpal blood flow. Am J Ortho Dentofacial Orthop., v. 110, n. 3, p. 273$279,1996$.

6. BERGIUS, M.; BERGGREN, U.; KILIARIDIS, S. Experience of pain during an orthodontic procedure. Eur J Oral Sci., v 110, n 2, p. 92-98, 2002.

7. BONNER, R.; NOSSAL, R. Model for laser Doppler measurements of blood flow in tissue. Applied Optics., v. 20, n. 12, 1981.

8. BRODIN, P.; LINGE, L.; AARAS, H. Instant assessment of pulpal blood flow after orthodontic force application. J Orofac Orthop., v. 57, p. 306-309, 1996.

9. CHANG, C.H.; YU, H.S.; CHEN, G.S.; WU, J.R.; HUANG, T.Y.; YU, C.L. Deterioration of cutaneous microcirculatory status and its clinical correlation in tetralogy of Fallot. Microvasc Res. , v. 51, n. 1, p. 59-68, 1996.

10. CLOUGH, G.F.; BOUTSIOUKI, P.; CHURCH, M.K.; MICHEL, C.C. Effects of blood flow on the in vivo recovery of a small diffusible molecule by microdialysis in human skin. J Pharmacol Exp Ther., v. 302, n. 2, p. 681 686, 2002.

11. CONSOLARO, A. Reabsorçōes Dentárias nas Especialidades Clínicas. Maringá, PR: Dental Press, 2002.

12. DA SILVA FILHO, O.G.; DE FREITAS, S.F.; CAVASSAN, A. D.E. O. Prevalence of normal occlusion and malocclusion in Bauru (São Paulo) students. 2. Influence of socioeconomic level. Rev Odontol Univ. São Paulo., v. 4, n. 3, p. 189-196, 1990. 
13. DERRINGER, K.A.; JAGGERS, D.C.; LINDEN, R.W. Angiogenesis in human dental pulp following orthodontic tooth movement $J$ Dent Res., v. $75, n$. 10, p. 1761-1766, 1996.

14. EDUARDO, F.T.O.P. Avaliação da Fluxometria Laser Doppler como Teste da Vitalidade Pulpar. 2004. Dissertação (Mestrado em Tecnologia Nuclear), Universidade de São Paulo.

15. EVANS, D.; REID, J.; STRANG, R; STIRRUPS, D. A comparison of laser Doppler flowmetry with other methods of assessing the vitality of traumatized anterior teeth. Endod Dent Traumatol., v. 15, p. 284-290, 1999.

16. FARHAT, P.B. DE A. Modelagem dos efeitos térmicos e ópticos na polpa dentária durante a irradiação com os lasers de diodo e de neodímio. 2003. Dissertação (Mestrado em Lasers em odontologia) - Instituto de Pesquisas Energéticas e Nucleares.

17. FRISTAD, I.; KVINNSLAND, I.H. ; JONSSON, R.; HEYERAAS, K.J. Effect of intermittent long-lasting electrical tooth stimulation on pulpal blood flow and immunocompetent cells: a hemodynamic and immunohistochemical study in young rat molars. Exp Neurol. v. 146, n. 1, p. 230-239, 1997

18. GAENGLER, P.; MERTE, K. Effects of force application on periodontal blood circulation. A vital microscopic study in rats. J Periodontal Res., v. 18, n.1, p. 86-92, 1983.

19. GAZELIUS, B.; OLGART, L.; EDWALL, B. Restored vitality in luxated teeth assessed by laser Doppler flowmeter. Endod Dent Traumatol., v. 4, n. 4-6, p. $265-268,1988$.

20. GUEVARA, M.J.; McCLUGAGE, S.G. Jr. Effects of intrusive forces upon the microvasculature of the dental pulp. Angle Orthod., v. 50, n. 2, p. 129-134, 1980.

21. HALL, C.J.; FREER, T. J. The effects of early orthodontic force application on pulp test responses. Aust Dent J., v. 43, n. 5, p. 359-361, 1998.

22. HAMERSKY, P.A; WEIMER, A. D.; TAINTOR, J.F. The effect of orthodontic force application on the pulpal tissue respiration rate in the human premolar. Am J Orthod., v. 77, n. 4, p. 368-378, 1980.

23. HAMILTOM, R. S.; GUTTMAN, J. L. Endodontic-orthodontic relationships: a review of integrated treatment planning challenges, Int. Endod J., v. 32, n. 5 , p. $343-360,1999$.

24. HARTMANN, A.; AZÉRAD, J.; BOUCHER, Y. Environmental effects on laser Doppler pulpal blood-flow measurements in man, Arch. Oral Biol., v. 41, n. 4, p. 333-339, 1996.

25. HAUG, S.R.; BRUDVIK, P.; FRISTAD, I.; HEYERAAS, K.J. Sympathectomy causes increased root resorption after orthodontic tooth movement in rats: immunohistochemical study Cell Tissue Res., v. 313, n. 2, p. 167-175, 2003. 
26. HAUG, S.R.; HEYERAAS, K.J. Effects of sympathectomy on experimentally induced pulpal inflammation and periapical lesions in rats. Neuroscience., $v$. 120, n. 3, p. 827-836, 2003.

27. HEYERAAS, K.J.; BERGGREEN, E. Interstitial fluid pressure in normal and inflamed pulp. Crit Rev Oral Biol Med., v. 10, n. 3, p. 328-336, 1999.

28. HEYERAAS, K.J.; KIM, S.; RAAB, W.H.; BYERS, M.R.; LIU, M. Effect of electrical tooth stimulation on blood flow, interstitial fluid pressure and substance $P$ and CGRP-immunoreactive nerve fibers in the low compliant cat dental pulp. Microvasc Res., v. 47, n. 3, p. 329-343, 1994.

29. HEYERAAS, K.J.; KVINNSLAND, I. Tissue pressure and blood flow in pulpal inflammation Proc Finn Dent Soc., v. 88, n.1, p. 393-401, 1992.

30. HILDEBRAND, C.; FRIED, K.; TUISKU, F.; JOHANSSON, C.S. Teeth and tooth nerves Prog Neurobiol., v. 45, n. 3, p. 165-222, 1995.

31. IKAWA, M.; FUJIWARA, M.; HORIUCHI, H. The effect of short-term tooth intrusion on human pulpal blood flow measured by laser Doppler flowmetry. Arch Oral Biol., v. 46, n. 9, p. 781-787, 2001.

32. INGOLFSSON, A. E. R.; TRONSTAD, L.; HERSH, E; RIVA, C. E. Effect of probe design on the suitability of laser Doppler flowmetry in vitality testing of human teeth. Endod Dent Traumatol., v. 9, n. 2, p. 65-70, 1993.

33. INGOLFSSON, A. E. R.; TRONSTAD, L.; HERSH, E.; RIVA, C.E. Efficacy of laser Doppler flowmetry in determining pulp vitality of human teeth. Endod Dent Traumatol., v. 10, n. 2, p. 83-87, 1994.

34. INGOLFSSON, A. E, R.; TRONSTAD, L.; RIVA, C. E. Reliability of laser Doppler Flowmetry in Testing Vitality of Human Teeth. Endod Dent Traumatol., v. 10, n. 4, p. 185-187, 1994.

35. KERDVONGBUNDIT, $\quad V_{\text {.; }}$ SIRIRAT, M.; SIRIKULSATHEAN, A.; KASETSUWAN, J.; HASEGAWA, A. Blood flow and human periodontal status. Odontology.,v. 90, n. 1, p. 52-56, 2002.

36. KERDVONGBUNDIT, V.; VONGSAVAN, N.; SOO-AMPON, S.; HASEGAWA, $A$. Microcirculation and micromorphology of healthy and inflamed gingiva. Odontology., v. 91, n. 1, p. 19-25, 2003.

37. KIM, S. Neurovascular interactions in the dental pulp in health and inflammation. J f Endod., v. 16, n. 2, p. 48-53, 1990.

38. KIM, S.; DORSCHER-KIM, J. Hemodynamic regulation of the dental pulp in a low compliance environment. J Endod., v. 15, n. 9, p. 404-408, 1989.

39. KUSY, R.P. A review of contemporary archwires: their properties and characteristics. Angle Orthod., v. 67, n. 3, p. 197-207, 1997. 
40. KVINNSLAND, S.; HEYERAAS, K.; SNORRE, E. Effect of experimental tooth movement on periodontal and pulpal blood flow. Eur. J Orthod., v. 11, n. 3, p. 200-205, 1989.

41. LUNDY, F.T.; LINDEN, G.J. Neuropeptides and neurogenic mechanisms in oral and periodontal inflammation. Crit Rev Oral Biol Med., v. 15, n. 2, p. 82$98,2004$.

42. McDONALD, F.; PITT FORD, T. R. Blood Flow changes in permanent maxillary canines during retraction. Europ. J. Orthod., v. 16, n. 1, p. 01-09, 1994.

43. MELING, T.R.; ODEGAARD, J. The effect of short-term temperature changes on superelastic nickel-titanium archwires activated in orthodontic bending. Am J Orthod Dentofacial Orthop., v. 119, n. 3, p. 263-273, 2001.

44. MESAROS, S. V.; TROPE, M.; MAIXNER, W.; BURKES, E.J. Comparison of two laser Doppler systems on the measurement of blood flow of premolar teeth under different pulpal conditions. Int Endod J., v. 30, n. 3, p. 167-174, 1997.

45. MESAROS, S. V.; TROPE, M. Revascularization of traumatized teeth assessed by laser Doppler flowmetry: case report. Endod. Dent Traumatol., v. 13, n. 1, p. $24-30,1997$.

46. MICHAELSON, P.L.; HOLLAND, G.R. Is pulpitis painful? Int Endod J. v. 35, n. 10, p. 829-832, 2002.

47. MIURA, F.; MOGI, M.; OHURA, Y.; HAMANAKA, $H$. The super-elastic property of the Japanese NiTi alloy wire for use in orthodontics Am J Orthod Dentofacial Orthop., v. 90, n. 1, p. 1-10, 1986.

48. MORSE, P.H. Resorption of upper incisor following orthodontic treatment. Dent Pract Dent Rec., v. 22, n.1, p. 21-35, 1971.

49. NARHI, M. Interaction between the autonomic and sensory nerves in the dental pulp. Proc Finn Dent Soc., v. 85, n. (4-5), p. 389-393, 1989.

50. NILSSON G E, "Signal processor for laser Doppler tissue flowmeters", Med. \& Biol. Eng. Comp., p. 343-348, 1984.

51. NOGUEIRA, A.L.F. Laser Doppler como meio diagnóstico para vitalidade pulpar-Estabelecimento de parâmetros de leitura. 2003. Dissertação (Mestrado em Odontologia) -Universidade de São Paulo.

52. NOGUEIRA, G. E. C.; ZEZELL, D. M.; EDUARDO, L. R. P.; VIEIRA JR., N. D.; BALDOCHI, S. L.; ROSSI, W. Desenvolvimento de um Sensor de Fluxo Sangüíneo via Técnica Laser Doppler. In: XVII ENC. NACIONAL DE FÍSICA DA MATERIA CONDENSADA, Florianopolis, p. 1-3, 2000.

53. NUKI, K.; HOCK, J. The organisation of the gingival vasculature. $J$ Periodontal Res., v. 9, n. 5, p. 305-313, 1974. 
54. ODOR, T. M.; PITT FORD, T. R.; McDONALD, F. Effect of wavelength and bandwidth on the clinical reliability of laser Doppler recordings. Endod. Dent. Traumatol., v. 12, n. 1, p. 09-15, 1996a.

55. ODOR, T. M.; PITT FORD, T. R.; MCDONALD, F. Effect of probe design and bandwidth on laser Doppler readings from vital and root-filled teeth, Med. Eng. Phys., v. 18, n. 5, p. 359-364, 1996b.

56. ODOR, T. M.; WATSON, T. F.; PITT FORD, T. R.; MCDONALD, F. Pattern of transmission of laser light in teeth, Int. Endod J. v. 29, n. 4, p. 228-234, 1996c.

57. OLGART, L. Neural control of pulpal blood flow. Crit Rev Oral Biol Med., v. 7, n. 2, p. 159-171, 1996.

58. OPPENNHEIM, A. Human tissue reponse to orthodontic intervetion of short and long duration. Am J Orthodontics., v. 28, p. 263-301, 1942.

59. PACKMAN, H.; SHOHER, I.; STEIN, R.S. Vascular responses in the human periodontal ligament and alveolar bone detected by photoelectric plethysmography: the effect of force application to the tooth $J$ Periodontol., v. 48, n. 4, p. $194-200,1977$.

60. PAIVA, J.B.; NETO, J.R.; ABRĀO, J.; JUNIOR, H.C. Movimento ortodôntico e reabsorção radicular. Ortodontia. v. 31, n. 2, p.101-111, 1998.

61. PASHLEY, D.H. Mechanistic analysis of fluid distribution across the pulpodentin complex. J Endod. v. 18, p. 72-77, 1992.

62. PATH, M.G.; MEYER, M. W. Quantification of pulpal blood flow in developing teeth of dogs. J Dent Res., v. 56, n. 10, p. 1245-1254, 1977.

63. PATINO-MARIN, N.; MARTINEZ, F.; LOYOLA-RODRIGUEZ, J.P.; TENORIO-GOVEA, E.; BRITO-ORTA, M.D.; RODRIGUEZ-MARTINEZ, M. A novel procedure for evaluating gingival perfusion status using laser-Doppler flowmetry. J Clin Periodontol. v. 32, n. 3, p. 231-237, 2005.

64. PIMENTA, F.J.; AS, A. R; GOMEZ, R.S. Lymphangiogenesis in human dental pulp Int Endod J., v. 36, n. 12, p. 853-856, 2003.

65. POPEL, A.S.; JOHNSON, P.C. Microcirculation and Hemorheology.Annu. Rev. Fluid. Mech. V. 37, p. 43-69, 2005.

66. PROFFIT, W. R. Ortodontia Contemporânea. Terceira edição. Rio de Janeiro, Editora Guanabara Koogan, 2000.

67. RAMSAY, D. S.; ARTUN, J.; MARTINEN,S.S. Reliability of pulpal blood flow measurements utilizing laser Doppler flowmetry, J. Dental Res., v. 70, n. 11, p. 1427-1430, 1991. 
68. REITAN, K. The initial tissue reaction incident to orthodontic tooth movement as related to the influence of function. Acta Odontol Scand Supp, v. 6, p. 01-240, 1951.

69. REN, Y.; MALTHA, J.C.; KUIJPERS-JAGTMAN, A.M. Optimum force magnitude for orthodontic tooth movement: a systematic literature review. Angle Orthod. , v. 73, n. 1, p. 86-92, 2003.

70. REN, Y.; MALTHA, J.C.; KUIJPERS-JAGTMAN, A.M. The rat as a model for orthodontic tooth movement - a critical review and a proposed solution Eur $J$ Orthod. , v. 26, n. 5, p. 483-490, 2004.

71. RODD, H.D.; BOISSONADE, F.M. Immunocytochemical investigation of neurovascular relationships in human tooth pulp. J Anat., v. 202, n.2, p.195203, 2003.

72. ROEBUCK, E.M.; EVANS, D.J.; STIRRUPS, D.; STRANG, R. The effect of wavelength, bandwidth, and probe design and position on assessing the vitality of anterior teeth with laser Doppler flowmetry. Int J Pediatric Dent. v. 10, n. 3, p. 213-220, 2000.

73. ROEYKENS, H.; VAN MAELE, G.; DE MOOR, R. MARTENS, L . Reliability of laser Doppler flowmetry in a 2-probe assessment of pulpal blood flow. Oral Surg Oral Med Oral Pathol Oral Radiol Endod., v. 87, n. 6, p. 742-748, 1999.

74. RYGH, P.; BOWLING, K.; HOVLANDSDAL, L.; WILLIAMS, S. Activation of the vascular system: a main mediator of periodontal fiber remodeling in orthodontic tooth movement. Am J Orthod., v. 89, n.6, p.453-468, 1986.

75. SANO, Y.; IKAWA M.; SUGAWARA J.; HORIUCHI, H.; MITANI, H. The effect of continuous intrusive force on human pulpal blood flow. Eur J. Orthod., v. 24, n. 2, p. 159-166, 2002.

76. SCHEININ, A.; PHOTO, M.; LUOSTARINEN, L. Defense reactions of the pulp with reference to circulation. An experimental study in rats. Int Dent $J$., v. 17, n. 2, p. $461-475,1967$.

77. SMITH, R.J.; BURSTONE, C.J. Mechanics of tooth movement. Am J Orthod., v. 85, n. 4,p. 294-307, 1984.

78. SOO-AMPON, S; VONGSAVAN, N; SOO-AMPON, M; CHUCKPAIWONG, S; MATTHEWS, B. The sources of laser Doppler blood-flow signals recorded from human teeth. Arch. Oral Biol., v. 48, n. 5, p. 353-360, 2003.

79. STAXRUD, L.E.; JAKOBSSON, A.; KVERNEBO, K.; SALERUD, E.G. Spatial and temporal evaluation of locally induced skin trauma recorded with laser Doppler techniques. Microvasc Res., v. 51, n. 1, p. 69-79, 1996.

80. STENVIK, A.; MJOR, I.A. Pulp and dentine reactions to experimental tooth intrusion. A histologic study of the initial changes. Am J Orthod., v. 57, n. 4, p. $370-385,1970$. 
81. SUBAY, R.K.; KAYA, H.; TARIM, B.; SUBAY, A.; COX, C. F. Response of human pulpal tissue to orthodontic extrusive applications. J Endod., v. 27, n. 8, p. 508-511, 2001.

82. SUZUKI, H.; LIMA, R. S. Arco de retração anterior dupla chave(DKH Parker). Ortodontia., v. 34, n. 1, p. 73-78, 2001.

83. TONDER, K.J. The effect of variation in arterial blood pressure and baroreceptor reflexes on pulpal blood flow in dogs Arch Oral Biol., v. 20, n. (5-6), p. 345-349, 1975.

84. TONDER, K.J. Blood flow and vascular pressure in the dental pulp. Summary. Acta Odontol Scand., v. 38, n. 3, p. 135-144, 1980.

85. UNSTERSEHER, R.E.; NIEBERG, L.G.; WEIMER, A.D.; DYER, J.K. The response of human pulpal tissue after orthodontic force application. $A m \boldsymbol{J}$ Orthod Dentofacial Orthop., v. 92, n. 3, p. 220-224, 1987.

86. VANDEVSKA-RADUNOVIC, V.; KRISTIANSEN, A. B.; HEYERAAS, K . J.; KVINNSLAND, $S$. Changes in blood circulation in teeth and supporting tissues incident to experimental tooth movement. Eur $J$ Orthod., v. 16, n. 5 , p. 361-369, 1994.

87. VANDEVSKA-RADUNOVIC, V.; KVINNSLAND, S.; KVINNSLAND, I.H. Effect of experimental tooth movement on nerve fibres immunoreactive to calcitonin gene-related peptide, protein gene product 9.5 , and blood vessel density and distribution in rats. Eur J Orthod., v. 19, n. 5, p. 517-529, 1997.

88. VANDEVSKA-RADUNOVIC, $V$. Neural modulation of inflammatory reactions in dental tissues incident to orthodontic tooth movement. Eur $J$ Orthod., v. 21, n. 3, p. 231-247, 1999.

89. VILLA, P.A.; OBERTI, G.; MONCADA, C.A.; VASSEUR, O.; JARAMILLO, A.; TOBON, D.; AGUDELO, J.A. Pulp-dentine complex changes and root resorption during intrusive orthodontic tooth movement in patients prescribed nabumetone. J Endod., v. 31, n. 1, p. 61-66, 2005.

90. VON BOHL, M.; MALTHA, J.; VON DEN HOFF, H.; KUIJPERS-JAGTMAN, A.M. Changes in the periodontal ligament after experimental tooth movement using high and low continuous forces in beagle dogs. Angle Orthod., v. 74, n. 1, p. $16-25,2004$

91. VONGSAVAN, N.; MATTHEWS, B. Experiments on extracted teeth into the validity of using laser Doppler techniques for recording pulpal blood flow. Arch Oral Biol., v. 38, n. 5, p. 431-439, 1993.

92. WANDERLEY,M.T. Avaliação da fluxometria laser Doppler como método de diagnóstico da vitalidade pulpar em incisivos superiores decíduos. 2004. Tese (Doutorado em Odontologia (Pediatria) Universidade de São Paulo. 
93. YAMAGUCHI, K.; NANDA, R.S. Blood flow changes in gingival tissues due to the displacement of teeth. Angle Orthod., v. 62, n.4, p. 257-264, 1992.

94. YAMAGUCHI, K.; NANDA, R.S.; KAWATA, T. Effect of orthodontic forces on blood flow in human gingiva. Angle Orthod., v. 61, n. 3, p. 193-204, 1991.

95. YU, C.Y.; BOYD, N.M.; CRINGLE, S.J.; SU, E.N.; ALDER, V.A.; YU, D.Y. An in vitro comparison of the effects of vasoactive mediators on pulpal blood vessels in rat incisors. Arch Oral Biol. v. 47, n.10, p. 723-732, 2002 